SHELON CRISTINA SOUZA BANDECA (ORG.)

VANESSA MIGLIORINI URBAN (ORG.)

ANA CLÁUDIA RODRIGUES CHIBINSKI

DENISE STADLER WAMBIER

EDUARDO BAUML CAMPAGNOLI

FÁBIO ANDRÉ DOS SANTOS

FÁBIO BRASIL DE OLIVEIRA

GILSON CÉSAR NOBRE FRANCO

JOÃO CARLOS GOMES

LUÍS ANTÔNIO ESMERINO

NARA HELLEN CAMPANHA BOMBARDA

\title{
BOAS PRÁTICAS EM \\ BIOSSEGURANÇA DO CURSO \\ DE ODONTOLOGIA DA UEPG \\ PARA A PREVENÇÃO DE \\ INFECÇÃO DE COVID-19
}

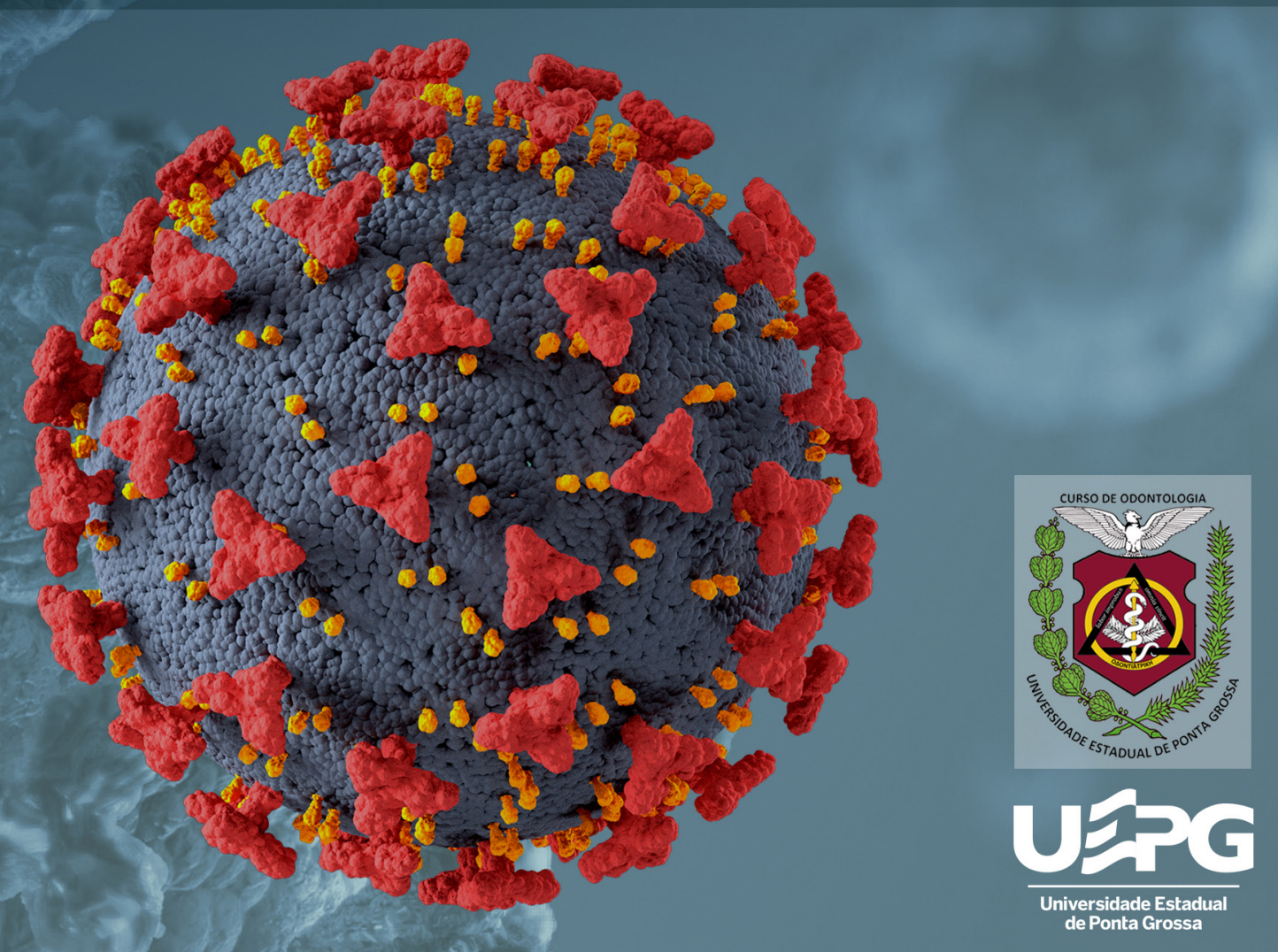




\title{
UNIVERSIDADE ESTADUAL DE PONTA GROSSA
}

\author{
Reitor \\ Miguel Sanches Neto \\ Vice-Reitor \\ Everson Augusto Krum
}

Pró-reitoria de Extensão e Assuntos Culturais

Clóris Regina Blanski Grden

Coordenadora do Curso de Odontologia

Luciana Dorochenko Martins

COMISSÃO DE CONTROLE DE INFECÇÃO ODONTOLÓGICA (CCIO) ODONTOLOGIA / UEPG

\author{
Presidente CCIO \\ Shelon Cristina Souza Bandeca \\ Membros CCIO \\ Eduardo Bauml Campagnoli \\ Fábio André dos Santos \\ João Carlos Gomes \\ Luís Antônio Esmerino \\ Nara Hellen Campanha Bombarda \\ Vanessa Migliorini Urban
}


Shelon Cristina Souza Bandeca (org.)

Vanessa Migliorini Urban (org.)

Ana Cláudia Rodrigues Chibinski

Denise Stadler Wambier

Eduardo Bauml Campagnoli

Fábio André dos Santos

Fábio Brasil de Oliveira

Gilson César Nobre Franco

João Carlos Gomes

Luís Antônio Esmerino

Nara Hellen Campanha Bombarda

\section{BOAS PRÁTICAS EM \\ BIOSSEGURANÇA DO CURSO \\ DE ODONTOLOGIA DA UEPG \\ PARA A PREVENÇÃO DE \\ INFECÇÃO DE COVID-19}
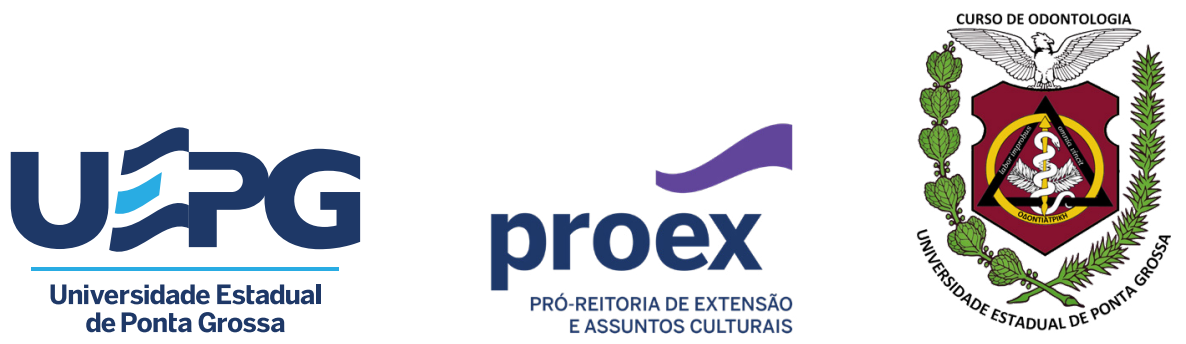


\title{
PROEX UEPG
}

Equipe Editorial

\section{Revisão de língua portuguesa}

Fábia Mariela de Biasi

\section{Capa, projeto gráfico e diagramação}

Andressa Marcondes

\author{
Apoio \\ Editora UEPG \\ Imagens retiradas de \\ https://br.freepik.com/ e www.flaticon.com/br/
}

B662

Boas práticas em biossegurança do Curso de Odontologia da UEPG para a prevenção de infecção de COVID-19 [livro eletrônico]/ Shelon Cristina Souza Bandeca (Org.); Vanessa Migliorini Urban (Org.). Ponta Grossa: UEPG, 2020.

102 p.; E-book PDF

ISBN: 978-65-86234-03-9

DOI: $10.5212 / 86234-03-9$

1. Corona vírus. 2. COVID-19 - prevenção. 3. Odontologia. 4. Protocolos - segurança. I. Bandeca, Shelon Cristina Souza (Org.). II. Urban, Vanessa Migliorini (Org.). III. T.

CDD: 617.6

Ficha Catalográfica elaborada por Maria Luzia F. B. dos Santos - CRB9/986 


\section{SUMÁRIO}

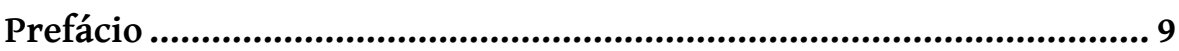

Considerações iniciais ....................................................................10

Protocolos de biossegurança referenciais utilizados para a elaboração do presente manual.

1 Orientações para a saída de casa e o deslocamento até a UEPG (pacientes, alunos, professores e técnicos) ............................16

2 Orientações para a chegada à UEPG (pacientes, alunos, professores e técnicos)......................................................................18

3 Equipe odontológica - professores, alunos e técnicos......................19

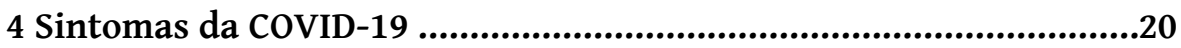

5 Agendamento de pacientes por telefone ou WhatsApp...................21

Formulário de triagem pré-consulta........................................................ 22

Agendamento de retorno .......................................................................... 23

6 Recepção - sala de espera .....................................................24

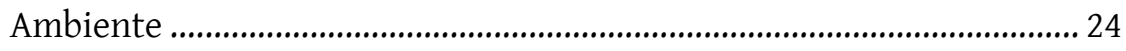

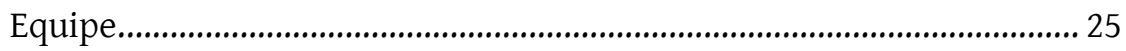

Atribuições da equipe da recepção............................................................ 25

7 Equipamentos de proteção individual (EPIs) .....................................27

Antes da paramentação .......................................................................... 27

Higienização correta das mãos ................................................................ 28

Paramentação - técnicos, professores e alunos ....................................... 29

Paramentação - professores e alunos (procedimentos cirúrgicos) $\quad 30$

Cuidados na utilização da máscara cirúrgica............................................... 31

Cuidados na utilização do respirador particulado - N95/PFF2S

ou equivalente ............................................................................................. 31

Cuidados na utilização dos óculos de proteção/do protetor facial (face shield). 


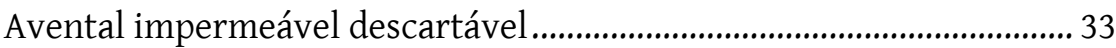

Paramentação - pacientes ............................................................................ 34

8 Cuidados durante $o$ atendimento de pacientes ...............................35

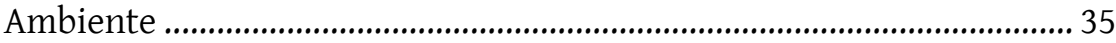

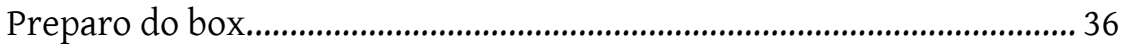

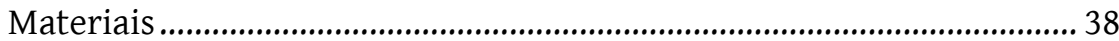

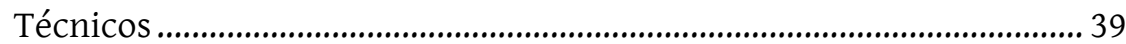

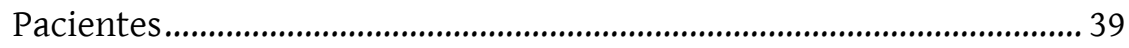

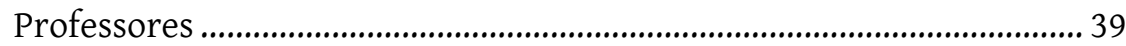

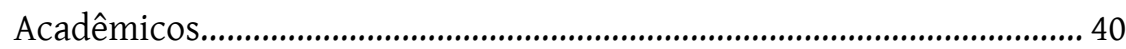

Medidas para o controle de aerossóis ......................................................... 41

9 Cuidados ao final do atendimento de pacientes ................................43

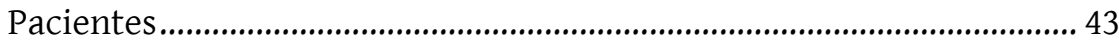

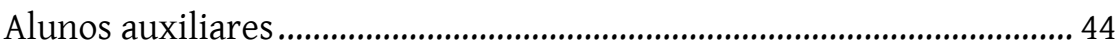

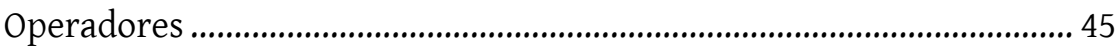

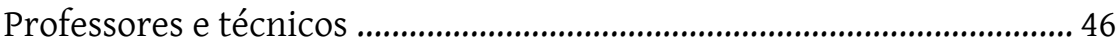

10 Protocolo de limpeza e esterilização da UEPG ................................47

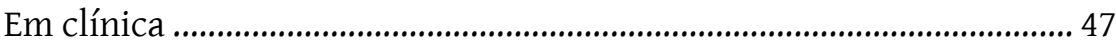

Clínica $\rightarrow$ expurgo ………………........................................................ 47

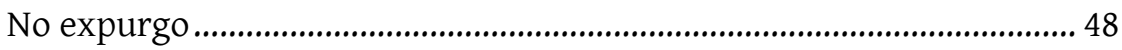

Expurgo $\rightarrow$ empacotamento ................................................................... 48

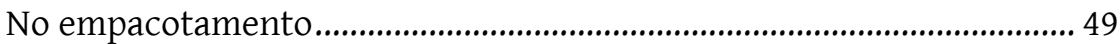

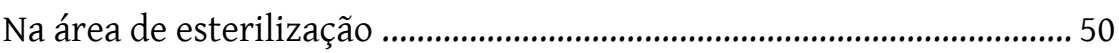

Armazenamento ....................................................................................... 50

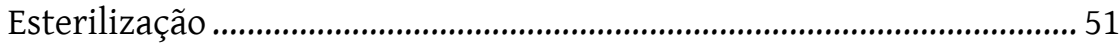

Funcionários do CME .......................................................................... 51

Para conhecimento, cabe aos funcionários do CME: ............................... 51

Alerta aos acadêmicos ............................................................................. 52

11 Limpeza e desinfecção terminal das clínicas .................................53

Técnicos, alunos auxiliares e professores .............................................. 53

$1^{\circ}$ Limpeza e desinfecção das tubulações dos equipos - técnicos............ 54

$2^{\circ}$ Limpeza e desinfecção das mesas, boxes e bancadas -

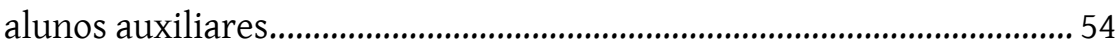


Desparamentação - professores e alunos auxiliares ........................... 56

Desparamentação - operadores ............................................................ 58

Como lavar as luvas de borracha:....................................................... 59

$3^{\circ}$ Limpeza e desinfecção final dos equipos e dos artigos e materiais de consumo utilizados durante a aula clínica - técnicos ...........................6 60

Desparamentação - técnicos (manejo dos resíduos) ............................ 61

4 Manejo dos resíduos - técnicos ............................................................... 62

Desparamentação final - técnicos ....................................................... 63

$5^{\circ}$ Limpeza dos pisos - auxiliares de serviços gerais ................................... 64

Procedimentos prévios à limpeza ........................................................ 64

Limpeza de pisos e superfícies de todo o ambiente odontológico 64

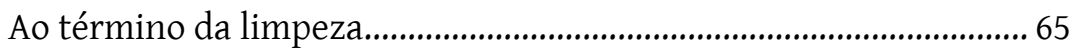

No depósito de material de limpeza (DML): ......................................... 65

Desparamentação no DML - auxiliares de serviços gerais.................. 66

Instruções para a remoção cuidadosa dos EPIs...................................... 67

12 Orientações para o retorno para casa (pacientes, acadêmicos, professores e técnicos) ..................................................69

\section{Processamento das roupas e dos sapatos}

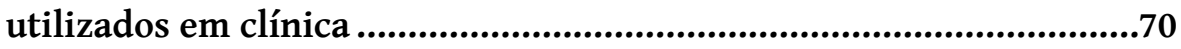

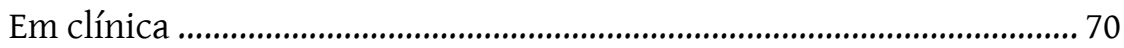

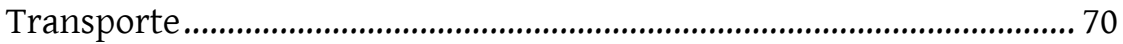

Ao chegar em casa...................................................................................... 71

Limpeza das máscaras caseiras ................................................................. 71

Descarte das máscaras caseiras................................................................... 72

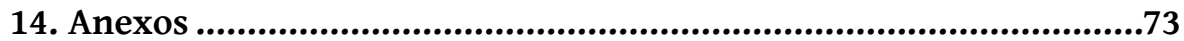

14.1 Particularidades - Radiologia.......................................................... 73

Cuidados na recepção do paciente ................................................... 73

Cuidados gerais............................................................................... 73

Protocolo de controle de infecção.................................................. 74

1. Paramentação ....................................................................... 74

2. Preparo da sala ..................................................................... 74

3. Preparo dos materiais ....................................................... 75

4. Preparo do paciente................................................................. 75 


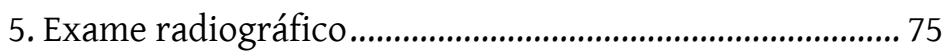

6. Após o exame radiográfico ................................................ 76

7. Processamento radiográfico.............................................. 76

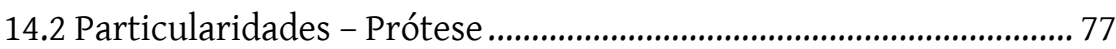

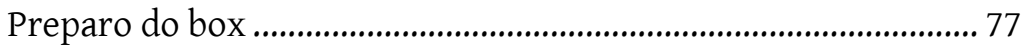

Ajustes clínicos extraorais de trabalhos protéticos ....................... 77

Desinfecção dos trabalhos protéticos (realizados pelo aluno auxiliar) após ajustes clínicos ............................................ 78

Procedimentos realizados no laboratório de prótese anexo ao dispensário clínico .......................................... 80

Procedimentos realizados no laboratório interno de

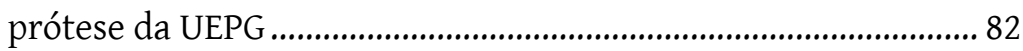

Ao receber os trabalhos protéticos nas clínicas da UEPG............. 82

Procedimentos de biossegurança para fluxo digital ...................... 82

Cuidados durante a execução de trabalhos utilizando

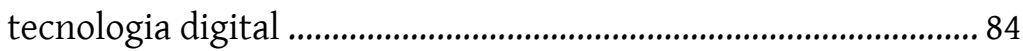

14.3 Particularidades - Odontopediatria................................................... 85

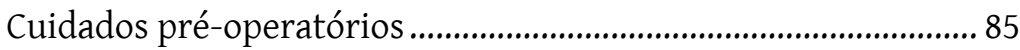

Por que fazer a videochamada? .................................................... 86

Vídeo do dentista realizando a paramentação.................................. 87

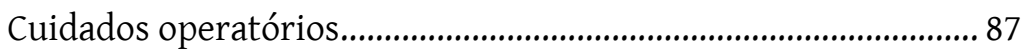

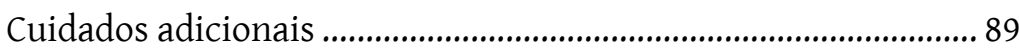

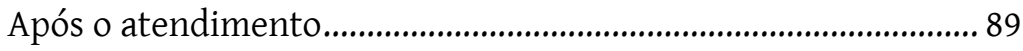

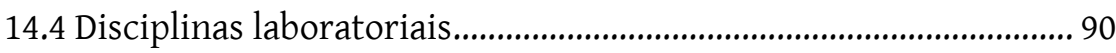

Medidas de proteção aluno/professor ......................................... 90

Medidas de proteção relacionadas ao ambiente .............................. 91

Medidas de proteção durante as aulas laboratoriais..................... 92

Medidas de proteção durante procedimentos laboratoriais ........... 93

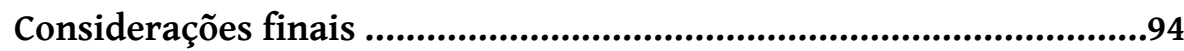

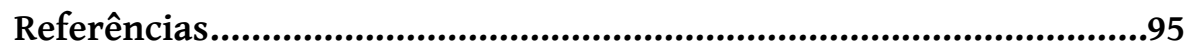

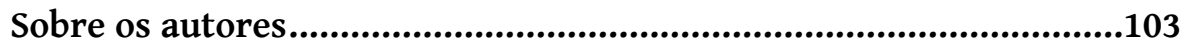




\section{PREFÁCIO}

Era uma segunda-feira, um dia normal de aula na UEPG, quando recebemos a mensagem sobre o decreto que informava que as atividades seriam paralisadas por duas semanas. O novo coronavírus estava se "espalhando" pelo país, e a medida era preventiva. Mas ninguém esperava que o que era para durar duas semanas se tornaria meses. Eque continuaríamos, mesmo após meses, com incertezas sobre o retorno das atividades presenciais. Ainda não sabemos até quando tudo o que estamos vivendo vai permanecer assim. Mas sabemos que essa situação com certeza está mudando a visão sobre nossa profissão. Eagora imaginamos que aquele dia normal de aula talvez demore, ou talvez nem volte a ser como um dia foi e, portanto, já falamos em um "novo normal".

Nesse novo normal, as importâncias estão mudando e o que, muitas vezes, era visto como chatices a serem cumpridas e exigências sem significado passam a ser nossa única alternativa de retorno - um protocolo de biossegurança extremamente bem conduzido. 0 novo normal mostra uma Odontologia mais segura, com muitas exigências e que valoriza a biossegurança como nunca antes. As mudanças mais significativas nas medidas de biossegurança antes do novo coronavírus aconteceram após o surgimento do vírus da imunodeficiência humana e, desde então, continuaram as mesmas até os dias de hoje. A situação atual exige novas medidas de biossegurança. Portanto, existe a necessidade de adotar novas medidas no retorno às práticas clínicas e laboratoriais.

Pensando nisso, nós, da Comissão de Controle de Infecção Odontológica da UEPG, elaboramos um novo protocolo geral de biossegurança. Este protocolo geral foi concebido considerando a literatura disponível, mas também o bom senso e o que é possível adaptar em nossas dependências para oferecer atendimento à população de forma segura, bem como para que possamos nos sentir seguros. Tudo que parece exagero énecessidade. Mas lembrem que estamos todos juntos nesta nova etapa, um ajudando o outro e todos pensando em um único propósito: exercer nossas atividades com conhecimento, técnica, ciência e com muita biossegurança.

Profa. Dra. Shelon Cristina Souza Bandeca 


\section{CONSIDERAÇÕES INICIAIS}

No final de 2019, um surto de pneumonia com etiologia desconhecida foi registrado na cidade de Wuhan, na República Popular da China. A maioria dos casos foi relacionada a um mercado local de frutos do mar que vendia animais vivos, tendo sido sugerido que os patógenos eram transmitidos de animais para seres humanos e, na sequência, entre humanos. O patógeno foi identificado e nomeado como novo coronavírus 2019 (2019-nCoV ou SARS-CoV-2), e a enfermidade foi denominada doença pelo coronavírus 2019 (COVID-19) (GE et al., 2020). No dia 11 de março de 2020, a Organização Mundial de Saúde declarou, então, estado de pandemia decorrente do novo coronavírus.

As principais manifestações clínicas são de natureza respiratória e ocorrem após um período médio de incubação de cinco dias (entre 0 a 24 dias) (ODEH et al., 2020). Os sintomas/sinais clínicos comuns são: febre, tosse seca, falta de ar, mialgia, fadiga e resultados de tomografia computadorizada torácica anormal (pneumonia bilateral com opacidade em vidro fosco e sombras irregulares bilaterais). Os sintomas menos comuns são: dor de cabeça, produção de expectoração, hemoptise (expectoração de sangue proveniente de pulmões, traqueia e brônquios), dor de estômago, tonturas, náusea, diarreia e vômito (BAGHIZADEH FINI, 2020). Além disso, a anosmia súbita (perda do olfato) ou a hiposmia (diminuição do olfato), com ou sem ageusia (perda do paladar) e sem obstrução nasal, está sendo considerada sintoma patognomônico da doença.

Qualquer pessoa contaminada pode apresentar sintomas leves ou graves (PEREIRA et al., Fiocruz, 2020), existindo uma grande variação entre os países para os casos assintomáticos positivos registrados, indicando cerca de $80 \%$ dos casos infectados como assintomáticos (DAY, 2020; ODEH et al., 2020). Apesar de os pacientes com COVID-19 sintomáticos serem considerados a principal fonte de transmissão, pacientes assintomáticos e pacientes em período de incubação (pré-sintomáticos) também são portadores de SARS-CoV-2 (ROTHE et al., 2020) e podem transmitir a doença. Resta provar se 
os pacientes em fase de recuperação são uma fonte potencial de transmissão (MENG et al., 2020; ROTHE et al., 2020).

Risco aumentado de infecção tem sido apontado para pacientes idosos e/ou com comorbidades, principalmente hipertensão, diabetes, cardiopatia isquêmica, doença pulmonar, asma e obesidade. Uma possível explicação para essa associação estaria relacionada à natureza dessas condições e aos tipos de medicamentos utilizados em seus tratamentos. Em pacientes hipertensos e diabéticos, as quantidades circulantes de enzima conversora de angiotensina-2 (ACE2) são aumentadas. Além disso, alguns medicamentos, incluindo certos anti-hipertensivos, agem como inibidores da ACE, o que aumenta ainda mais a ACE2 e, como SARS-CoV-2 liga-se à membrana da célula hospedeira via ACE2, nota-se um risco aumentado de infecção (ODEH et al., 2020). Os resultados do estudo de Xu et al. (2020) mostraram que a ACE2 pode ser expressa na cavidade oral e é altamente enriquecida em células epiteliais, indicando um risco potencialmente alto para a suscetibilidade infecciosa de 2019-nCov (XU et al., 2020).

A transmissão de SARS-CoV-2 em ambientes odontológicos pode ocorrer por quatro vias principais: (1) exposição direta a secreções respiratórias contendo gotículas, sangue, saliva ou outros materiais do paciente; (2) contato indireto por meio de superfícies e/ou instrumentos contaminados; (3) inalação de vírus suspensos no ar; e (4) contato da mucosa (nasal, oral e conjuntival) com gotículas e aerossóis contendo infecção, os quais são propelidos pela tosse e pela fala por indivíduos que não utilizam máscara (CHEN, 2020; FALLAHI et al., 2020; KAMPF et al., 2020) (Figura 1). 
Figura 1. Ilustração das rotas de transmissão de SARS-CoV-2 no ambiente odontológico

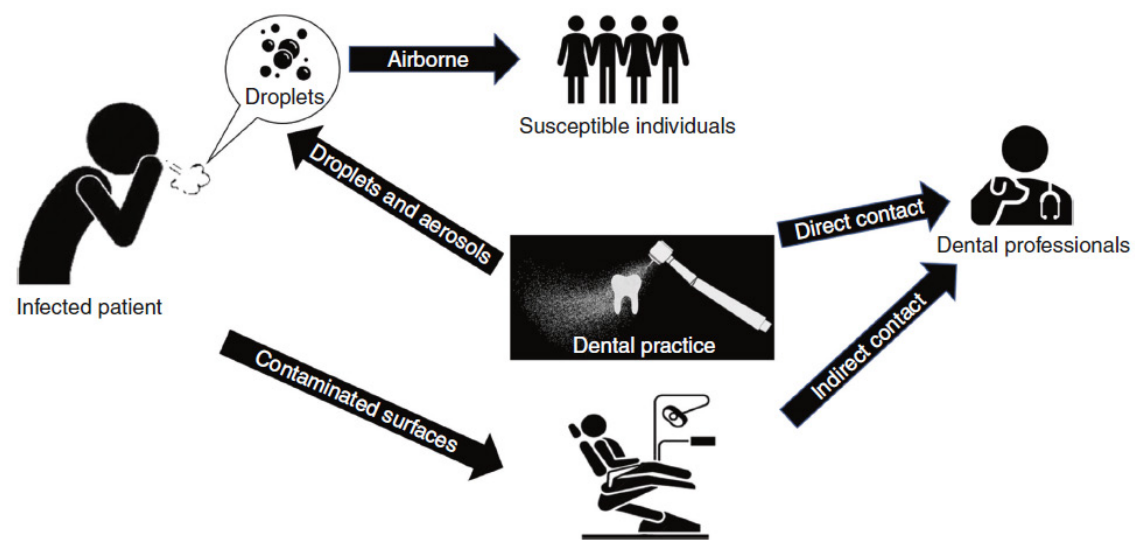

Fonte: Fonte: PENG, X. et al. Transmission routes of 2019-nCoV and controls in dental practice. Int J Oral Sci., v. 12, n. 1, p. 9, Mar 2020.

O risco biológico de transmissão por inalação é extremamente alto na realização de procedimentos odontológicos em razão do uso de peças de mão e outros instrumentos sob irrigação, o que favorece a difusão de partículas de aerossol de saliva, sangue e secreções. Além disso, essa produção de aerossol facilita a contaminação do ambiente e dos instrumentos e superfícies (IZZETTI et al., 2020; MENG et al., 2020; PENG et al., 2020). Portanto, é essencial compreender a transmissão pelo aerossol e suas implicações na Odontologia (GE et al., 2020). A distância e o tempo em que as partículas permanecem suspensas no ar são determinadas por seu tamanho, sua velocidade de assentamento, sua umidade relativa e seu fluxo de ar (PENG et al., 2020). Gotículas com diâmetro superior a $5 \mu \mathrm{m}$, em virtude da gravidade, caem rapidamente no chão (1 metro) e, portanto, a transmissão requer proximidade física entre um indivíduo infectado e um suscetível. Pequenas gotículas ou resíduos de partículas de gotículas evaporadas criam um aerossol com baixa velocidade de sedimentação, de modo que podem permanecer no ar por um período maior e com capacidade de difusão superior a 1 metro (GE et al., 2020; LO GIUDICE, 2020).

Considerando, assim, as características únicas dos procedimentos odontológicos de geração de um grande número de gotículas 
e aerossóis, as medidas-padrão de proteção rotineiramente empregadas não são eficazes o suficiente para impedir a propagação da COVID-19, e medidas especiais de precaução devem ser implementadas durante esse período especial de pandemia (GE et al., 2020; IZZETTI et al., 2020). Em janeiro de 2020, a Comissão Nacional de Saúde da China adicionou a COVID-19 à categoria de doenças infecciosas do grupo B, que inclui SARS (Síndrome Respiratória Aguda Grave) e influenza aviária de alta patogenicidade. No entanto, também sugeriu que todos os profissionais de saúde usem medidas de proteção semelhantes às indicadas para infecções do grupo A, categoria reservada para patógenos extremamente infecciosos, como cólera e peste (MENG et al., 2020).

Durante as práticas odontológicas, a disseminação de microrganismos orais irradia principalmente para o rosto do dentista, particularmente na parte interna dos olhos e ao redor do nariz, que são áreas importantes para a transmissão de infecções (GE et al., 2020; NEJATIDANESH et al., 2013). Entre as medidas de biossegurança, a higiene das mãos tem sido considerada a precaução mais crítica para reduzir o risco de transmissão de microrganismos aos pacientes (MENG et al., 2020). E, entre os equipamentos de proteção individual (EPIs), são recomendados: luvas, máscaras cirúrgicas para procedimentos sem aerossol, aventais impermeáveis descartáveis e óculos de proteção e protetores faciais (face shield). Como as gotículas respiratórias são a principal via de transmissão de SARS-CoV-2, os respiradores particulados (N-95 ou PFF2) são indicados para procedimentos odontológicos geradores de aerossol (MENG et al., 2020). Tendo em vista que a carga viral na saliva humana é muito alta, os enxágues com enxaguatórios bucais antissépticos podem reduzir apenas a quantidade microbiana infecciosa, mas não conseguem eliminar o vírus na saliva (MENG et al., 2020; PENG et al., 2020; SPAGNUOLO et al., 2020).

Os coronavírus podem manter ativamente sua virulência em temperatura ambiente de 2 horas a 9 dias, e sua atividade é significativamente maior em ambientes mais úmidos. Portanto, manter as superfícies limpas e secas tem um papel relevante na prevenção da transmissão de 2019-nCoV (FALLAHI et al., 2020; KAMPF et al., 
2020). Além da redução da geração de aerossóis ser listada entre as medidas preventivas contra a infecção por SARS-CoV-2, é recomendável renovar frequentemente o ar interno, abrindo as janelas ou usando ventilação mecânica, possivelmente entre pacientes (IZZETTI et al., 2020). Ainda, como o vírus tende a permanecer em partículas suspensas no ar, é indicado não remover os EPIs faciais (proteção de olhos, boca e nariz) antes de se retirar da área contaminada (IZZETTI et al., 2020).

Diante da complexidade de medidas que deverão ser implementadas, este documento contempla normas e diretrizes de biossegurança de Agências Institucionais Reguladoras nacionais e internacionais (Quadro 1). Este Manual foi organizado de modo a relacionar as precauções necessárias visando à prevenção da COVID-19, desde a saída de casa até o retorno a ela, para toda a equipe envolvida no atendimento odontológico dos pacientes. Por ser uma doença recente, são necessárias mais comprovações científicas e, nesse sentido, a atualização deste documento é demanda contínua. Ainda, uma vez que não se tem conhecimento se um indivíduo curado torna-se imune à doença e qual seria a durabilidade da imunidade adquirida para a COVID-19, os procedimentos aqui descritos devem ser seguidos por todos, inclusive por aqueles que já tiveram a doença (PEREIRA et al., Fiocruz, 2020). 


\section{PROTOCOLOS DE BIOSSEGURANÇA REFERENCIAIS UTILIZADOS PARA A ELABORAÇÃO DO PRESENTE MANUAL}

O protocolo de Biossegurança da UEPG teve como documentos referência os arquivos listados no Quadro 1. As demais fontes consultadas estão na lista de Referências, ao final desta obra.

\section{Quadro 1. Protocolos de Biossegurança contra a COVID-19}

\begin{tabular}{|c|c|}
\hline Agência Institucional & Documento Referência \\
\hline $\begin{array}{l}\text { Agência Nacional de Vigilância } \\
\text { Sanitária }\end{array}$ & $\begin{array}{c}\text { Orientações para Serviços de Saúde: Medidas de } \\
\text { Prevenção e Controle que Devem ser Adotadas } \\
\text { Durante a Assistência aos Casos Suspeitos ou } \\
\text { Confirmados de Infecção pelo Novo Coronavirus } \\
\text { (SARS-CoV-2) }\end{array}$ \\
\hline American Dental Association & $\begin{array}{l}\text { Releases Interim Guidance on Minimizing COVID-19 } \\
\text { Transmission Risk when Treating Dental Emergencies }\end{array}$ \\
\hline American Dental Association & Return to Work Interim: Guidance Toolkit \\
\hline $\begin{array}{l}\text { Associação Brasileira de Ensino } \\
\text { Odontológico }\end{array}$ & $\begin{array}{l}\text { Consenso ABENO: Biossegurança no Ensino } \\
\text { Odontológico Pós-Pandemia da COVID-19 }\end{array}$ \\
\hline $\begin{array}{c}\text { Centers for Disease Control and } \\
\text { Prevention }\end{array}$ & Guidance for Dental Settings \\
\hline Conselho Federal de Odontologia & $\begin{array}{c}\text { Manual de Boas Práticas em Biossegurança para } \\
\text { Ambientes Odontológicos }\end{array}$ \\
\hline $\begin{array}{l}\text { COVID-19 Dental Services Evidence } \\
\text { Review (CoDER) Working Group }\end{array}$ & $\begin{array}{l}\text { Recommendations for the Re-opening of Dental } \\
\text { Services: a Rapid Review of International Sources }\end{array}$ \\
\hline Governo do Estado do Paraná & $\begin{array}{c}\text { Orientações Referentes ao Atendimento Odontológico } \\
\text { nos Serviços Públicos Frente à COVID-19 }\end{array}$ \\
\hline
\end{tabular}




\section{ORIENTAÇÕES PARA A SAÍDA DE CASA E O DESLOCAMENTO ATÉ A UEPG (PACIENTES, ALUNOS, PROFESSORES E TÉCNICOS)}

- Lavar as mãos e o rosto com água e sabão;

- Vestir a máscara caseira limpa e seca (Figura 2), evitando tocar em sua superfície externa (utilização não recomendada para crianças menores de 2 anos, por apresentar risco de asfixia e rápido umedecimento);

Figura 2. A OMS (Organização Mundial de Saúde) atualizou as recomendações sobre o uso de máscaras de tecido (caseiras) como alternativa para redução do contágio pelo novo coronavírus. Para garantir uma proteção satisfatória, a máscara precisa ter uma camada de algodão para absorver a água e conter a umidade, uma camada intermediária que funciona como um filtro (p. ex.: polipropileno) e uma cada externa com tecido impermeável (p. ex.: poliéster).

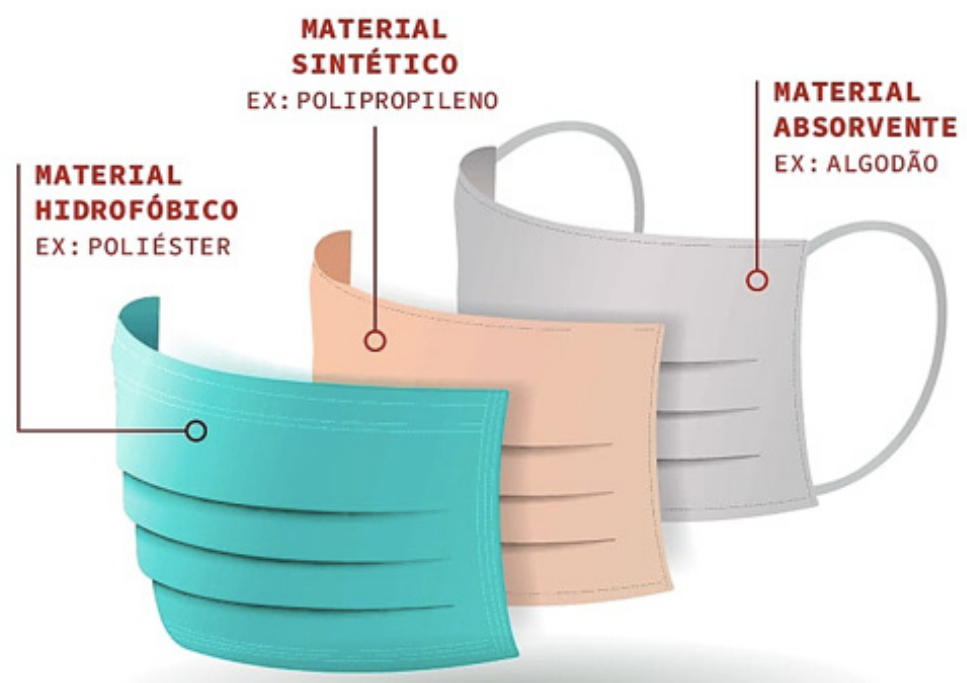

Fonte: Organização Mundial da Saúde

Fonte: BRASIL DE FATO. Brasil de Fato: uma visão popular do Brasil e do mundo. Saiba quais são os tecidos recomendados pela OMS para as máscaras de pano caseiras: Disponível em: https://www.brasildefato.com.br/2020/06/09/ saiba-quais-sao-os-tecidos-recomendados-pela-oms-para-as-mascaras-depano-caseira. Acesso em: 03 jul. 2020. 
- Não utilizar maquiagem ou barba;

- Manter unhas higienizadas e curtas. Unhas esmaltadas devem estar íntegras e lisas (sem descascados ou craquelados). É proibido o uso de unhas postiças e/ou com apliques em relevo;

- Utilizar calçados fechados e roupas que protejam o corpo;

- Não utilizar adornos (brincos, anéis, relógios, colares etc.);

- Levar à Universidade apenas os pertences necessários;

- Lembrar sempre: não tocar em nenhum local da face ou na máscara com as mãos não lavadas;

- Ao tossir ou espirrar, cobrir o nariz e a boca com um lenço ou com o braço (nunca com as mãos);

- Carregar álcool em gel 70\% para aplicar sempre que necessário. Realizar a higienização das mãos no caminho;

- Caso utilize transporte público, evitar encostar em qualquer superfície, manter o distanciamento entre pessoas de 2 metros, ficar próximo às janelas (sempre que possível, mantê-las abertas).
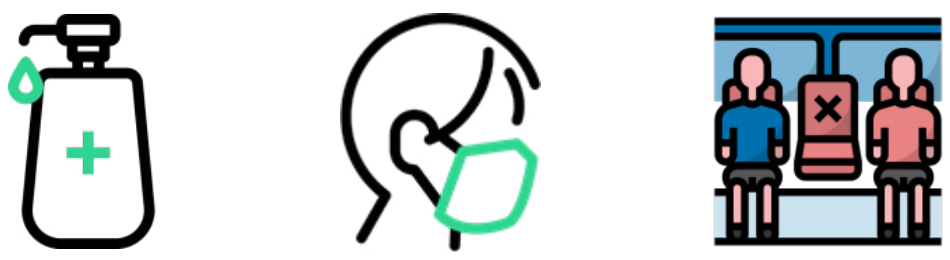


\section{ORIENTAÇÕES PARA A CHEGADA À UEPG (PACIENTES, ALUNOS, PROFESSORES E TÉCNICOS)}

- Higienizar as mãos com álcool em gel 70\%;

- Lembre que a máscara caseira deve ser utilizada o tempo todo, e deve ser retirada apenas quando for substituída pela máscara de uso clínico (professores, acadêmicos e técnicos) ou quando o paciente for submetido aos procedimentos clínicos (nesse caso, o paciente deve retirar a máscara);

- Acadêmicos, docentes e técnicos devem guardar todos os seus pertences, incluindo celulares e bolsas, em armários apropriados (importante levar à Universidade apenas o que for realmente necessário);

- Evitar contato físico;

- Manter sempre a distância de 2 metros entre as pessoas;

- Evitar sempre tocar a face ou a máscara com as mãos não lavadas;

- Não compartilhar objetos;

- Manter os ambientes sempre bem arejados;

- Ter sua própria garrafa de água e abastecê-la em casa;

- Caso precise utilizar o banheiro, abaixar a tampa do vaso sanitário para dar descarga e, após lavar as mãos, secá-las com papel-toalha e então fechar a torneira utilizando o papel-toalha (pois a torneira pode estar contaminada).
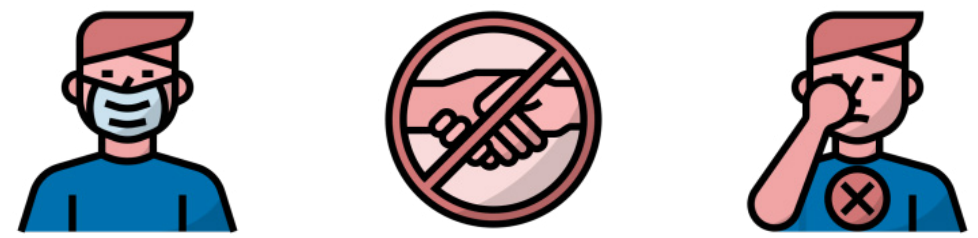


\section{EQUIPE ODONTOLÓGICA - PROFESSORES, ALUNOS E TÉCNICOS}

- Assegurar que todos tenham recebido a vacina contra a gripe;

- Questionar se o paciente apresenta algum sintoma relacionado à COVID-19 (item 04 - p. 20);

- Todos da equipe devem ser monitorados quanto aos sintomas (aferir febre antes do início do trabalho e ao final do dia, e questionar cada integrante sobre qualquer sintomatologia);

- Diariamente, ao chegar, fazer desinfecção das solas dos sapatos no tapete sanitizante na porta de entrada do bloco;

- Antes de ir para a clínica, deixar todos os pertences que não forem ser utilizados em clínica em local apropriado (armários).

IMPORTANTE: Anteriormente ao início das atividades, será realizado teste imunocromatográfico (teste rápido) em todos os professores, alunos e técnicos. Os testes rápidos para o novo coronavírus são de fácil execução e conseguem fornecer resultados entre $10 \mathrm{e}$ 30 minutos.
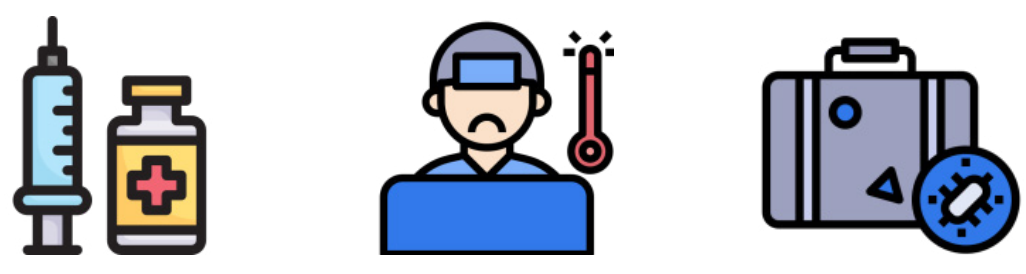


\section{SINTOMAS DA COVID-19}

\section{Sintomas mais comuns:}

- febre;

- tosse seca;

- cansaço.

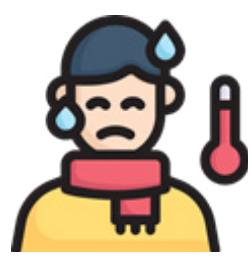

\section{Sintomas menos comuns:}

- dores e desconfortos;

- dor de garganta;

- diarreia;

- conjuntivite;

- dor de cabeça;

- perda de paladar ou olfato;

- erupção cutânea ou descoloração dos dedos das mãos ou dos pés.

\section{Sintomas graves:}

- dificuldade de respirar ou falta de ar;

- dor ou pressão no peito;

- perda da fala ou dos movimentos.
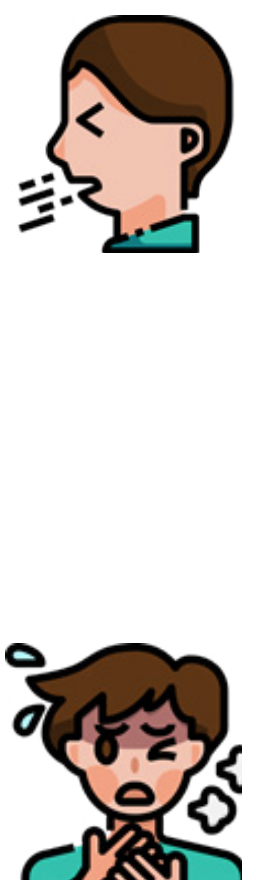


\section{AGENDAMENTO DE PACIENTES POR TELEFONE OU WHATSAPP}

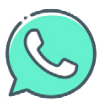

- Realizar uma triagem inicial por telefone (ligação ou WhatsApp);

- Questionar se o paciente apresenta qualquer um dos sintomas de infecção respiratória (Figura 3) ou se teve contato com pacientes suspeitos de COVID-19. Caso alguma resposta seja SIM, adiar a consulta;

- Pacientes com sintomas respiratórios SOMENTE deverão ser agendados em casos de urgência e emergência e, nesse caso, serão encaminhados para atendimento no Hospital Universitário/UEPG;

- Orientar os pacientes para que evitem levar acompanhantes;

- Orientar os pacientes para que venham para a consulta usando máscara caseira e tragam uma máscara caseira adicional para utilizar no retorno para casa;

- Orientar os pacientes para que não venham para a consulta utilizando esmalte nas unhas das mãos, pois ele prejudica a avaliação de sua saturação de oxigênio com oxímetro;

- Orientar os pacientes para que não se atrasem nem cheguem muito antes do horário agendado;

- Orientar os pacientes para que, sempre que possível, nos dias que comparecerem às consultas, sigam direto para casa e não fiquem circulando por outros locais desnecessariamente;

- Realizar anamnese específica para registrar a condição de saúde dos pacientes. Essas perguntas devem ser repetidas a cada novo agendamento. 


\section{Formulário de triagem pré-consulta}

Figura 3. Anamnese específica pré-consulta para registro das condições de saúde do paciente e do acompanhante, se houver, baseada nas informações contidas em: AMERICAN DENTAL ASSOCIATION. Return to work interim guidance toolkit. ADA, may 2020. Disponível em: https://success.ada.org/ /media/CPS/ Files/Open\%20Files/ADA_Return_to_Work_Toolkit.pdf. Acesso em: 28 jul. 2020.

Paciente/Acompanhante:

\begin{tabular}{|c|c|c|c|c|}
\hline Temperatura corporal: & \multicolumn{2}{|l|}{ Data: } & & $\stackrel{\circ}{C}$ \\
\hline Saturação de oxigênio: & \multicolumn{2}{|l|}{ Data: } & \multicolumn{2}{|r|}{$\%$} \\
\hline \multirow{2}{*}{ Anamnese: } & \multicolumn{2}{|c|}{ Antes da consulta } & \multicolumn{2}{|c|}{ Na clínica } \\
\hline & \multicolumn{2}{|l|}{ Data: } & \multicolumn{2}{|l|}{ Data: } \\
\hline $\begin{array}{l}\text { Você ou alguém do seu convívio } \\
\text { teve febre ou se sentiu "quente" } \\
\text { recentemente ( } 14 \text { a } 21 \text { dias)? }\end{array}$ & ( ) Sim & ( ） Não & ( ) Sim & ( ） Não \\
\hline $\begin{array}{l}\text { Você ou alguém do seu convívio está } \\
\text { com falta de ar ou outras dificuldades } \\
\text { em respirar? }\end{array}$ & ( ) Sim & ( ） Não & ( ) Sim & ( ） Não \\
\hline $\begin{array}{l}\text { Você ou alguém do seu convívio está } \\
\text { com tosse? }\end{array}$ & ( ) Sim & ( ) Não & ( ) Sim & ( ） Não \\
\hline $\begin{array}{l}\text { Você ou alguém do seu convívio tem } \\
\text { quaisquer outros sintomas de gripe, } \\
\text { distúrbios gastrointestinais, dor de } \\
\text { cabeça ou fadiga? }\end{array}$ & ( ) Sim & ( ) Não & ( ) Sim & ( ） Não \\
\hline $\begin{array}{l}\text { Você ou alguém do seu convívio teve } \\
\text { recentemente perda do olfato ou do } \\
\text { paladar? }\end{array}$ & ( ) Sim & ( ) Não & ( ) Sim & ( ） Não \\
\hline $\begin{array}{l}\text { Você ou alguém do seu convívio tem } \\
\text { ou teve contato com algum paciente } \\
\text { positivo confirmado para COVID-19? }\end{array}$ & ( ) Sim & ( ) Não & ( ) Sim & ( ) Não \\
\hline $\begin{array}{l}\text { Você ou alguém do seu convívio esteve } \\
\text { hospitalizado ou acompanhando alguém } \\
\text { hospitalizado recentemente? }\end{array}$ & ( ) Sim & ( ) Não & ( ) Sim & ( ) Não \\
\hline Você tem mais de 60 anos? & ( ) Sim & ( ) Não & ( ) Sim & ( ) Não \\
\hline $\begin{array}{l}\text { Você tem doenças cardíacas, } \\
\text { pulmonares, renais, diabetes ou alguma } \\
\text { doença auto-imune? }\end{array}$ & ( ) Sim & ( ） Não & ( ) Sim & ( ) Não \\
\hline Você está grávida? & ( ) Sim & ( ) Não & ( ) Sim & ( ) Não \\
\hline
\end{tabular}




\section{Agendamento de retorno}

- O aluno deve acompanhar o paciente nas próximas semanas (14 dias) para identificar a presença ou não de sintomas e registrar as condições conforme Figura 3;

- 0 aluno deve fazer contato prévio por telefone/WhatsApp confirmando retorno;

- A cada nova consulta, deve ser repetida a anamnese prévia (Figura 3) e devem ser reforçadas as orientações sobre o uso da máscara caseira, a higienização das mãos, a etiqueta respiratória, sobre não tocar olhos, nariz e boca e fazer distanciamento social (p. 18). 


\section{RECEPÇÃO - SALA DE ESPERA}

\section{Ambiente}

- Respeitar o distanciamento para filas (caso ocorram - no entanto, EVITAR) de, no mínimo, 2 metros entre as pessoas. Essa recomendação consta em alerta visual para que o paciente possa entender as demarcações no piso;

- Respeitar o distanciamento mínimo de 2 metros também nos assentos, de acordo com as sinalizações daqueles que não poderão ser utilizados;

- Bebedouros não serão utilizados, pois estarão inativados;

- Intensificar a limpeza e a desinfecção de objetos e superfícies passíveis de contaminação, principalmente maçanetas, interruptores de luz, corrimões etc.;

- Deve haver alertas visuais em locais estratégicos (área de espera, próximo às clínicas odontológicas e banheiros), fornecendo aos pacientes e acompanhantes (quando necessária a presença destes) instruções sobre a correta higienização das mãos com água e sabão e preparação alcoólica a 70\%, higiene respiratória/etiqueta de tosse e sobre evitar tocar olhos, nariz e boca com as mãos não higienizadas;

- Deve haver a presença de dispensadores de álcool 70\% (inclusive na entrada da clínica), papel-toalha não reciclável e lixeira com pedal para descartes;

- Nos banheiros, disponibilizar dispensadores de sabonete líquido, suporte para papel-toalha, papel-toalha e lixeira com pedal;

- Lixeiras grandes e sinalizadas para cada tipo de lixo devem estar disponíveis;

- O ambiente deve ser mantido ventilado, se possível, com janelas e portas abertas. 


\section{Equipe}

- Recepcionista e ALUNO CIRCULANTE EXTERNO;

- Funções da recepcionista: realizar os agendamentos, triagem por telefone/WhatsApp e triagem inicial presencial;

- Funções do aluno circulante externo: conduzir o paciente e assegurar que o paciente vá ao banheiro antes da consulta, para evitar que ele fique saindo da clínica depois de paramentado. Assegurar também que o paciente faça a higienização correta das mãos antes da entrada na clínica (utilizando água e sabão e álcool em gel 70\%); além de ajudar na organização da sala de espera, para que não haja aglomeração (orientar os pacientes para que se posicionem conforme as demarcações realizadas, respeitando o distanciamento adequado);

- Paramentação: máscara cirúrgica, gorro, óculos de proteção com abas laterais e protetor facial, avental descartável gola alta, luvas de procedimentos e sapatos fechados.

\section{Atribuições da equipe da recepção}

- Caso o paciente não esteja com máscara caseira, fornecer uma máscara cirúrgica para que ele use até o momento da realização do procedimento odontológico;

- Realizar a aferição de temperatura na recepção antes da entrada do paciente na clínica (Febrícula: $\geq 37,3^{\circ} \mathrm{C}$; Febre: $\geq 37,8$ ${ }^{\circ} \mathrm{C}$; Febre alta: $\geq 39{ }^{\circ} \mathrm{C}$ );

- Instruir os pacientes a informar caso tenham algum sintoma de infecção respiratória (por exemplo: tosse, coriza, dificuldade para respirar e outros);

- Encaminhar o paciente diretamente à clínica correspondente ao seu agendamento;

- Reforçar o pedido de que o paciente realize a higiene das mãos; 
- Estimular o paciente a realizar a higiene das mãos antes de entrar na clínica odontológica para atendimento (dispensadores de álcool 70\% na entrada da clínica);

- O ALUNO CIRCULANTE EXTERNO deve acompanhar a lavagem alcoólica das mãos dos pacientes - orientando-os para que ela seja realizada por 20 a 30 segundos;

- Antes de entrar na clínica, o ALUNO CIRCULANTE EXTERNO deve orientar o paciente sobre a necessidade de limpar e desinfetar objetos e superfícies, como seus celulares (na entrada da clínica, os pertences dos pacientes serão colocados em sacos plásticos limpos, e os pacientes os levarão consigo até o box de atendimento);

- Se possível, manter os ambientes ventilados (janelas abertas);

- Eliminar ou restringir o uso de itens compartilhados por pacientes, como canetas, pranchetas e telefones. Se for necessário assinar algum documento, estimular o paciente a utilizar sua própria caneta ou fornecer sobreluvas descartáveis para manusear a caneta da recepção;

- Realizar a limpeza e a desinfecção dos itens compartilhados por pacientes, quando for necessária a utilização destes.
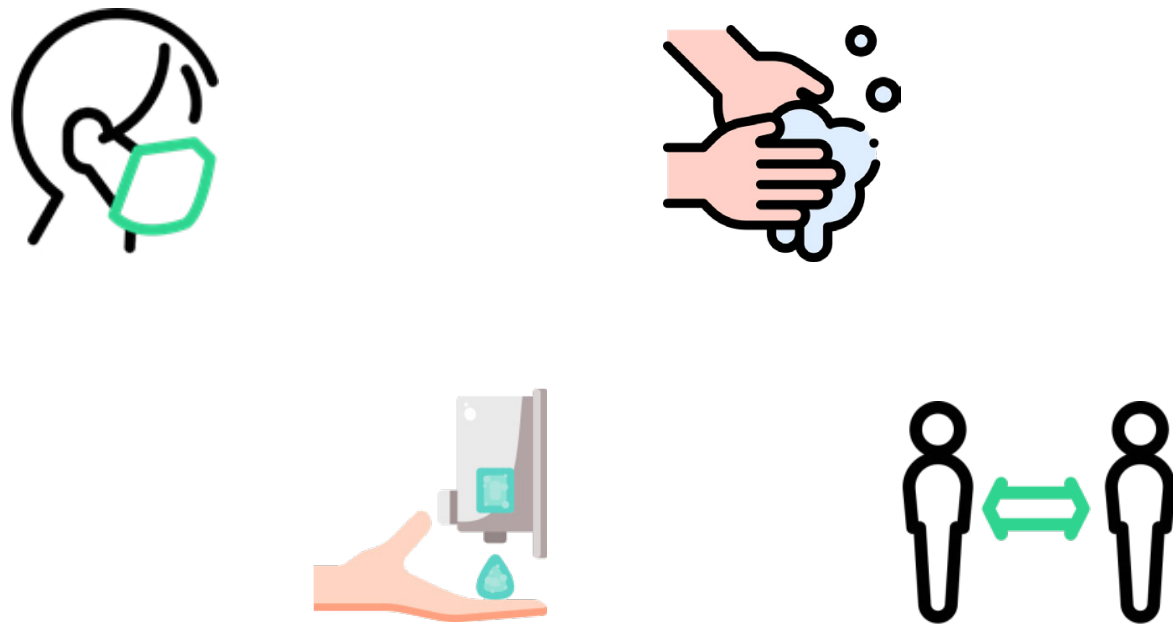


\section{EQUIPAMENTOS DE PROTEÇÃO INDIVIDUAL (EPIS)}

\section{Antes da paramentação}

- O material pessoal deve ficar no armário dentro de sacolas plásticas descartáveis;

- Levar para a clínica apenas o que for utilizar durante o atendimento;

- Ir ao banheiro e beber água, para evitar que precise sair da clínica depois de paramentado;

- Evitar ir à Universidade com acessórios e adereços. No entanto, se os estiver utilizando, retirar esses objetos antes de entrar na clínica e mantê-los em seus armários ou em local apropriado;

- Prender os cabelos, manter as unhas curtas, não usar maquiagem e/ou protetor solar (pois eles dificultam o selamento do respirador N95);

- Barbear-se (a barba dificulta o selamento do respirador N95);

- Os professores, alunos e técnicos devem ser orientados para que evitem tocar, com luvas ou outros EPIs contaminados ou com as mãos contaminadas, superfícies próximas ao paciente (p. ex.: mobiliário e equipamentos para a saúde) e, também, aquelas fora do ambiente próximo ao paciente;

- Higienizar corretamente as mãos. 


\section{Higienização correta das mãos}

Figura 4. Higienização correta das mãos com preparações alcoólicas e com água e sabonete

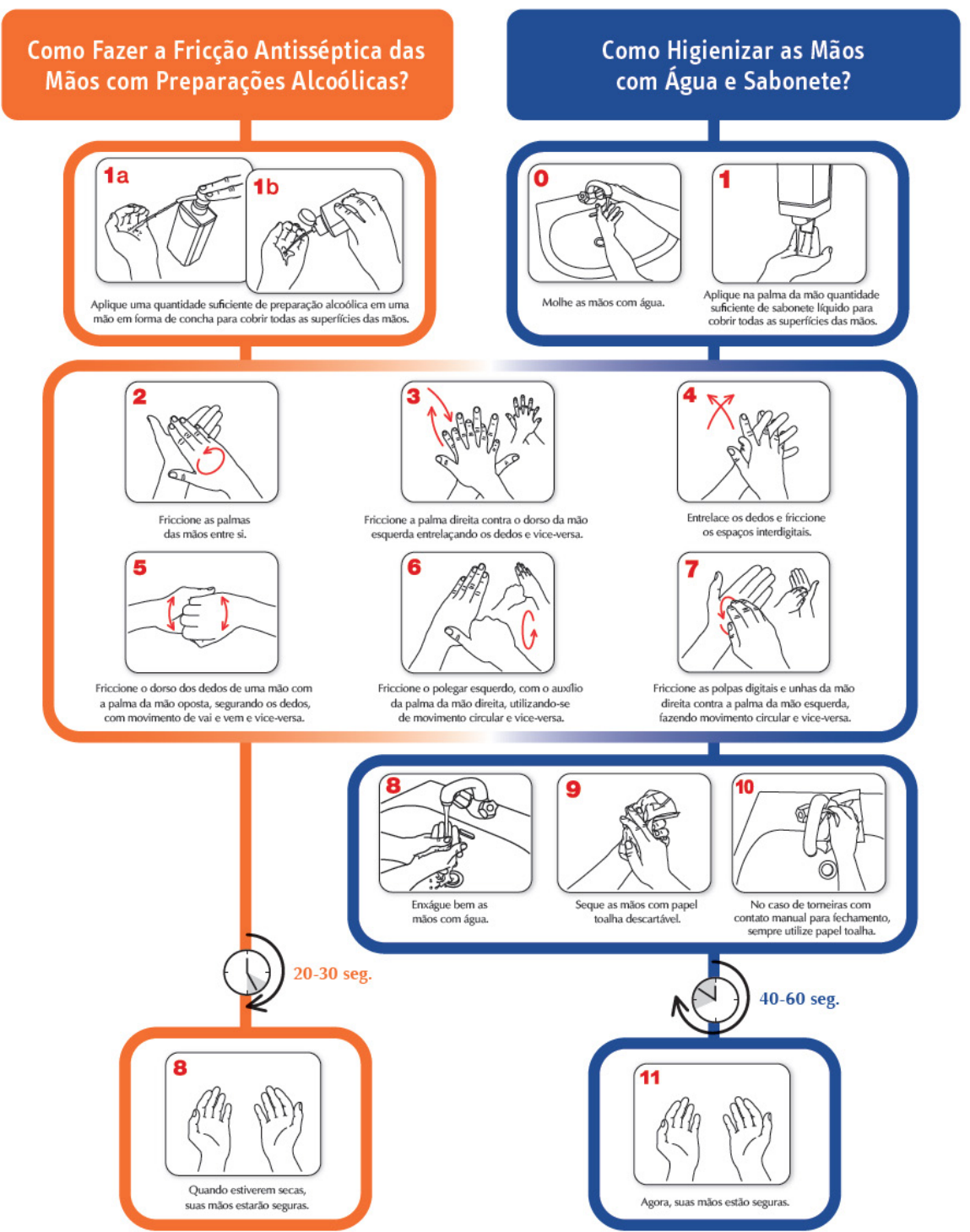

Fonte: BRASIL. Agência Nacional de Vigilância Sanitária. Como fazer higiene das mãos com preparação alcoólica e com sabonete líquido e água: cartaz. ANVISA. Disponível em: https://www20.anvisa.gov.br/segurancadopaciente/ index.php/publicacoes/item/cartaz-como-fazer-higiene-das-maos-compreparacao-alcoolica-e-com-sabonete-liquido-e-agua. Acesso em: 04 jun. 2020. 


\section{Paramentação - técnicos, professores e alunos}

\begin{tabular}{|c|}
\hline Higienizar as solas dos sapatos em tapete sanitizante \\
\hline Higienizar as mãos com água e sabão \\
\hline $\begin{array}{l}\text { Retirar a máscara caseira e acondicionar em sacos plásticos } \\
\text { novos e limpos }\end{array}$ \\
\hline Higienização alcoólica das mãos \\
\hline $\begin{array}{l}\text { Higienizar o rosto com água e sabão por } 20 \text { s ou com gaze e } \\
\text { clorexidina a } 0,2 \%\end{array}$ \\
\hline Higienização alcoólica das mãos \\
\hline Vestir pijama cirúrgico de mangas longas \\
\hline Colocar respirador N95/PFF2S ou similar \\
\hline $\begin{array}{l}\text { Realizar o teste de verificação da vedação do respirador } \\
\text { N95 ou similar }\end{array}$ \\
\hline $\begin{array}{l}\text { Vestir sapatos apropriados emborrachados e } \\
\text { antiderrapantes (devem ser utilizados com meias grossas) }\end{array}$ \\
\hline Higienização alcoólica das mãos \\
\hline Colocar óculos de proteção \\
\hline Colocar gorro (gramatura de $30 \mathrm{~g} / \mathrm{m}^{2}$ ) \\
\hline Colocar protetor facial (face shield) \\
\hline $\begin{array}{l}\text { Vestir avental descartável impermeável } \\
\text { (gramatura minima de } 50 \mathrm{~g} / \mathrm{m}^{2} \text { ) }\end{array}$ \\
\hline Calçar luvas de procedimento \\
\hline
\end{tabular}




\section{Paramentação - professores e alunos (procedimentos cirúrgicos)}

Higienizar as solas dos sapatos em tapete sanitizante
Higienizar as mãos com água e sabão
Hização alcoólica das mãos
Higienizar o rosto com água e sabão por 20 s ou com gaze e
Costidina a 0,2\%




\section{Cuidados na utilização da máscara cirúrgica}

- IMPORTANTE: a máscara cirúrgica indicada é a tripla descartável (tipo IIR);

- Não tocar na máscara enquanto ela estiver em uso. No entanto, caso a toque, higienizar as mãos imediatamente;

- Durante o procedimento, substituir a máscara por uma nova, limpa e seca, assim que a antiga ficar suja ou úmida;

- Remover a máscara usando a técnica apropriada (não toque a parte externa da máscara, remova-a sempre pelas tiras).

\section{Cuidados na utilização do respirador particulado - N95/PFF2S ou equivalente}

- Ele deve ser utilizado em procedimentos com risco de geração de aerossóis;

- O respirador particulado com válvula não deve ser utilizado quando há necessidade de campo estéril no paciente, pois o ar exalado não é filtrado;

- A forma de uso, a manipulação e o armazenamento devem seguir as recomendações do fabricante;

- Ajustá-lo adequadamente à face e realizar o teste de verificação da vedação:https://www.youtube.com/watch?v=UB3lN1VdH_I

- Após adequação do respirador e o início do trabalho, jamais o puxe de modo a afastá-lo da face, uma vez que isso comprometerá sua vedação. Se necessário algum ajuste durante o uso, utilize um par de luvas de procedimento novo, efetue o ajuste e depois descarte as luvas no lixo biológico;

- Em razão da pandemia, excepcionalmente neste momento, é permitida a reutilização desses respiradores (no máximo, por 4-5 vezes). No entanto, eles precisam ser utilizados com o face shield (protetor facial); devem ser devidamente acondicionados; 
sua integridade precisa ser avaliada: se está sujo, úmido e qual seu tempo de uso. Se não estiver vedando adequadamente a face do profissional, ele deve ser descartado;

- Na reutilização de um respirador N95, calce um novo par de luvas de procedimento para realizar sua colocação e, principalmente, faça o teste de verificação de vedação; em seguida, descarte as luvas em lixo biológico e higienize novamente as mãos;

- Não utilize máscara cirúrgica sobreposta ao respirador N95, pois, além de não garantir proteção de filtração ou de contaminação, isso também pode levar ao desperdício de mais um EPI. Não utilize máscara cirúrgica por baixo do respirador N95, uma vez que isso compromete a vedação do respirador particulado;

- Remoção pelos elásticos: se, no processo de remoção, houver contaminação da parte interna, descarte o respirador imediatamente. Os vírus permanecem suspensos no aerossol, então, para sua proteção, não remova o respirador no ambiente clínico;

- Armazenamento do respirador N95: acondicione-o de forma a mantê-lo íntegro, limpo e seco para o próximo uso. Utilize embalagens plásticas desde que elas não fiquem hermeticamente fechadas: https://www.youtube.com/ watch?v=3lnChqvmw24. Acondicione os elásticos do respirador de forma que não sejam contaminados e de modo a facilitar a retirada do respirador da embalagem. 


\section{Cuidados na utilização dos óculos de proteção/do protetor facial (face shield)}

- Os óculos e os protetores são de uso exclusivo de cada profissional;

- Imediatamente após o uso, realizar a limpeza com água e sabão e a posterior desinfecção com álcool líquido a 70\% (se o material for compatível), hipoclorito de sódio ou outro desinfetante recomendado;

- Se o protetor facial tiver sujidade visível, lavá-lo com água e sabão/detergente e, só depois da limpeza, fazer desinfecção de acordo com as instruções recomendadas pelo fabricante.

Figura 5. Sequência de paramentação - EPIs faciais

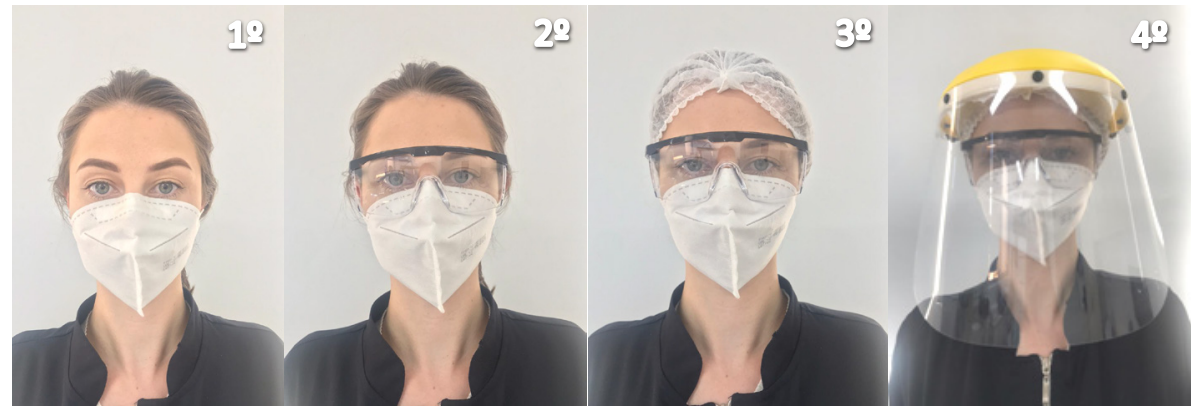

Foto baseada no artigo de FRANCO, J.B. et al. Cuidados odontológicos na era do COVID-19: recomendações para procedimentos odontológicos e profissionais. Rev Assoc Paul Cir Dent., v. 74, n. 1, p. 18-21, mar 2020.

\section{Avental impermeável descartável}

OBSERVAÇÃo: Caso haja falta de aventais impermeáveis com gramatura de $50 \mathrm{~g} / \mathrm{m}^{2}$, admite-se a utilização de aventais com menor gramatura (mínimo $30 \mathrm{~g} / \mathrm{m}^{2}$ ) desde que o fabricante assegure que esse produto seja impermeável. 


\section{Paramentação - pacientes}

o paciente já deverá estar usando máscara caseira. Assim que o paciente entrar na clínica, deve receber um kit de paramentação (gorro, avental fino, propés) fornecido pelo ALUNO CIRCULANTE INTERNO:

- Orientar o paciente a higienizar as solas dos sapatos no tapete sanitizante;

- O paciente deverá fazer a higienização alcoólica das mãos sob a orientação do ALUNO CIRCULANTE INTERNO;

- O paciente deverá colocar o gorro;

- O paciente deverá vestir o avental descartável;

- O ALUNO CIRCULANTE INTERNO deve conduzir o paciente até o box dos alunos que irão atendê-lo. Nesse momento, solicitar ao paciente que vista os propés , realize a higienização alcoólica das mãos e, então, o aluno (AUXILIAR) pode colocar os óculos de proteção no paciente;

- Pedir para o paciente retirar a máscara caseira apenas no momento da realização do procedimento clínico (nesse momento, o aluno AUXILIAR deve fornecer um saco plástico para o paciente guardar a máscara);

- Realizar a higienização do rosto do paciente com gaze e clorexidina a $0,2 \%$. 


\section{CUIDADOS DURANTE 0 ATENDIMENTO DE PACIENTES}

\section{Ambiente}

- Os atendimentos devem ser realizados em equipos alternados, apesar das divisórias entre os boxes, a fim de obter maior distância entre alunos, pacientes e professores;

- As atividades devem ser planejadas com turmas menores, respeitando-se: a ocupação máxima de $50 \%$ da capacidade da sala clínica, o espaço mínimo de $1,2 \mathrm{~m}^{2}$ por pessoa e o distanciamento de 2 metros entre as cadeiras;

- Limitar a quantidade de papéis na clínica. Deixar os avisos e as informações necessárias longe da área de atendimento aos pacientes. Encapar os avisos de papel com plástico ou utilizar avisos impressos em material que possa ser desinfetado;

- Cobrir o teclado, o computador e outros equipamentos, como máquinas fotográficas e celulares (quando for necessário levá-los ao ambiente clínico) e os que não podem ser removidos da clínica, com barreira de plástico filme e fazer frequentemente a desinfecção destes objetos;

- Manter o ambiente clínico ventilado com as janelas abertas;

- Sugere-se a NÃo utilização dos aparelhos de ar-condicionado. Se forem utilizados, não devem funcionar no modo recirculação. Para uma utilização segura, indica-se a avaliação especializada acompanhada por laudo técnico do sistema de ar-condicionado quanto à capacidade de renovação do ar. Existe a necessidade de renovação com ar novo de boa qualidade vindo do exterior (a vazão mínima de ar total para ambientes com usuários com infecção transmitida pelo ar é de $18 \mathrm{~m}^{3} / \mathrm{hm}^{2}$ - NBR 7256);

- Desinfetar, antes e após o atendimento, os materiais e os equipamentos a serem utilizados. 


\section{Preparo do box}

- Após a paramentação (p. 29, exceto a colocação do avental descartável), realizar a desinfecção das superfícies (Quadro 2):

\section{Quadro 2. Comparativo de desinfetantes de superfícies}

\begin{tabular}{|c|c|c|c|c|}
\hline $\begin{array}{c}\text { Soluções } \\
\text { desinfetantes }\end{array}$ & $\begin{array}{l}\text { Álcool } \\
\text { a 70\% }\end{array}$ & $\begin{array}{l}\text { Hipoclorito de } \\
\text { Sódio } \\
\text { a } 1 \%\end{array}$ & $\begin{array}{c}\text { Ácido } \\
\text { Peracético } \\
0,2 \text { a } 0,5 \%\end{array}$ & $\begin{array}{c}\text { Quaternários } \\
\text { de amônio 5a } \\
\text { geração com } \\
\text { biguanida } \\
\text { (7 a 9\% 1:200) }\end{array}$ \\
\hline Nível & Médio & Médio & Alto & Alto \\
\hline $\begin{array}{l}\text { Modo de } \\
\text { aplicação }\end{array}$ & $\begin{array}{l}\text { Fricção em } 3 \\
\text { etapas, } \\
\text { intercaladas } \\
\text { pelo tempo de } \\
\text { secagem } \\
\text { natural, } \\
\text { totalizando } 10 \\
\text { minutos }\end{array}$ & $\begin{array}{l}\text { Aplicação na } \\
\text { superfície por } 2 \\
\text { a } 5 \text { minutos }\end{array}$ & $\begin{array}{l}\text { Aplicação na } \\
\text { superfície por } \\
\text { tempo indicado } \\
\text { pelo fabricante }\end{array}$ & $\begin{array}{l}\text { Aplicação na } \\
\text { superfície, } \\
\text { deixar agir por } \\
10 \text { minutos e } \\
\text { remover com } \\
\text { pano ou papel } \\
\text { descartável }\end{array}$ \\
\hline Vantagens & $\begin{array}{l}\text { Fácil aplicação; } \\
\text { ação rápida, } \\
\text { compatível com } \\
\text { artigos } \\
\text { metálicos, } \\
\text { superfícies e } \\
\text { tubetes } \\
\text { anestésicos }\end{array}$ & $\begin{array}{l}\text { Ação rápida, } \\
\text { indicado para } \\
\text { superfícies e } \\
\text { artigos não } \\
\text { metálicos e } \\
\text { materiais } \\
\text { termossensíveis }\end{array}$ & $\begin{array}{c}\text { Não forma } \\
\text { resíduos } \\
\text { tóxicos, efetivo } \\
\text { na presença de } \\
\text { matéria } \\
\text { orgânica, rápida } \\
\text { ação em baixa } \\
\text { temperatura, } \\
\text { indicado para } \\
\text { superfícies e } \\
\text { artigos não } \\
\text { metálicos }\end{array}$ & $\begin{array}{l}\text { Fácil aplicação, } \\
\text { compatível com } \\
\text { artigos } \\
\text { metálicos, } \\
\text { estável, baixa } \\
\text { toxicidade }\end{array}$ \\
\hline Desvantagens & $\begin{array}{l}\text { Volátil, } \\
\text { inativado por } \\
\text { matérias } \\
\text { orgânicas, } \\
\text { inflamável, } \\
\text { resseca } \\
\text { plásticos e } \\
\text { opacifica acrílico }\end{array}$ & $\begin{array}{l}\text { Instável, } \\
\text { corrosivo, } \\
\text { inativado por } \\
\text { matérias } \\
\text { orgânicas, } \\
\text { irritação de pele } \\
\text { e mucosas }\end{array}$ & $\begin{array}{l}\text { Instável quando } \\
\text { diluído, } \\
\text { corrosivo para } \\
\text { alguns tipos de } \\
\text { metais, odor }\end{array}$ & Custo \\
\hline
\end{tabular}

Fonte: PIRES, Fabiana Schneider; FONTANELLA, Vania. Consenso Abeno: biossegurança no ensino odontológico pós-pandemia da COVID-19. Porto Alegre: ABENO, 2020. 86p. Disponível em: http://www.abeno.org.br/arquivos/ downloads/retomada_de_praticas_seguras_no_ensino_odontologico.pdf. Acesso em: 03 jul. 2020. 
- Realizar a desinfecção antes do primeiro atendimento, durante trocas de pacientes (no atual momento, sugerimos o atendimento de apenas um paciente por dupla) e, também, ao final da clínica;

- Locais que devem ter barreiras (filmes de PVC ou sacos plásticos ou barreiras de polipropileno):

* Botões manuais de acionamento;

* Alças e botões de liga/desliga de refletores;

* Encosto de cabeça da cadeira odontológica;

* Braços da cadeira odontológica;

* Encosto do mocho;

* Canetas de alta e baixa rotação;

* Corpo da seringa tríplice;

* Ponta da seringa tríplice: colocar envoltório plástico (canudinho cortado com ponta $1 \mathrm{~cm}$ maior que a seringa);

* Pontas da unidade de sucção;

* Demais equipamentos a serem utilizados na área clínica. Ex.: fotopolimerizadores.

- Cobrir bancadas e carrinho auxiliar com campos descartáveis e impermeáveis;

- Não utilizar a cuspideira, dando preferência à sucção da saliva por meio de bomba à vácuo. Utilizá-la somente em casos de extrema necessidade;

- Acionar os instrumentos rotatórios e a seringa tríplice dentro de um saco plástico por 30 segundos antes do primeiro uso em cada paciente e aspirar a água de dentro do saco;

- Bancadas: apenas material que será utilizado no atendimento, previamente desinfetado e fornecido pelo ALUNO CIRCULANTE INTERNO, que deverá utilizar sobreluvas plásticas. 


\section{Materiais}

- Os materiais de uso compartilhado devem ser selecionados antes do atendimento, e o TÉCNICO responsável pela clínica deve fornecer e colocar barreiras antes de liberá-los para o ALUNO CIRCULANTE INTERNO;

- Distribuição dos materiais: delimitar uma área limpa e uma área suja;

* área limpa: o TÉCNICO que distribuirá os materiais de consumo deve estar paramentado (avental descartável, gorro descartável, respirador N95/PFF2S, protetor facial e luvas de procedimento);

* área suja: presença de reservatórios amplos e abertos para o depósito dos materiais utilizados no ambiente clínico;

- Realizar a desinfecção dos materiais de consumo ao final do atendimento ou quando houver necessidade de reutilização do material (hipoclorito de sódio a 1\%, álcool 70\%, ácido peracético a $0,2 \%$ ou quaternário de amônio de $5^{a}$ geração);

- Manter os materiais de consumo em recipientes fechados quando no box de atendimento clínico;

- ALUNO AUXILIAR: sempre manipular o material de consumo com a utilização de sobreluvas;

- Sempre que possível, trabalhar com o fracionamento dos materiais de consumo (p. ex.: gaze, algodão e gesso, entre outros).

IMPORTANTE: o planejamento dos atendimentos (sessão clínica) deve ser realizado anteriormente para a organização prévia dos materiais de consumo. 


\section{Técnicos}

- Levar até a clínica somente o necessário;

- Paramentar-se conforme descrito no tópico "Paramentação"(p. 29);

- Realizar os procedimentos de distribuição e desinfecção de materiais de consumo durante o atendimento dos pacientes;

- Realizar a desinfecção dos materiais também na ocasião em que estes forem recebidos do almoxarifado;

- Dar auxílio aos professores e aos acadêmicos.

\section{Pacientes}

IMEDIATAMENTE ANTES DO INÍCIO DO PROCEDIMENTO ODONTOLÓGICO:

1. Orientar o paciente a guardar sua máscara em um saco plástico;

2. O aluno AUXILIAR deve realizar a redução consistente da saliva residual do paciente por aspiração contínua. Colocar $15 \mathrm{~mL}$ da solução de gluconato de clorexidina a $0,12 \%$ sem álcool em um copo plástico grande e pedir ao paciente que bocheche por 1 minuto (cronometrado) e cuspa novamente no mesmo copo em que o agente químico estava. Então, o aluno deve fazer a sucção deste.

IMPORTANTE: Não utilizar cuspideira e evitar ao máximo a saída do paciente da clínica durante o atendimento.

\section{Professores}

- Levar até a clínica somente o material necessário;

- Utilizar todos os EPIs recomendados no tópico "Paramentação" (p. 29); 
- Durante o auxílio ao acadêmico:

1. A ABENO recomenda um docente para auxiliar, no máximo, quatro unidades de atendimento, cada uma constituída por dois estudantes trabalhando a quatro mãos;

2. Caso o docente faça apenas a avaliação visual, não há a necessidade obrigatória de troca de EPIs (com exceção das luvas, estas SEMPRE devem ser trocadas). Apesar disso, solicita-se que o docente use do bom senso. Caso note que algum EPI tenha sido contaminado, faça sua desinfecção/troca no caso do protetor facial ou dos óculos de proteção, ou substitua o EPI;

3. Caso o docente participe ativamente do procedimento, deve trocar todos os EPIs e fazer a limpeza e a desinfecção/troca dos óculos e do protetor facial.

\section{Acadêmicos}

- Antes do dia da clínica, discutir com o professor orientador o tratamento e os passos de atendimento, bem como os materiais a serem utilizados;

- Levar até a clínica somente o material necessário para o atendimento;

- Utilizar todos os EPIs recomendados no tópico "Paramentação" (p. 29);

- Nunca tocar o paciente desnecessariamente, nem o colega ou a si mesmo;

- Nunca ajustar a máscara, o respirador, os óculos ou o protetor facial sem realizar a antissepsia prévia das mãos (e também a higienização das mãos após o toque, quando a máscara já estiver contaminada);

- Acionar os instrumentos rotatórios e a seringa tríplice por, no mínimo, 30 segundos antes do primeiro uso naquele paciente;

- Realizar suturas com fios absorvíveis sempre que possível. 


\section{Medidas para o controle de aerossóis}

- Distância de 2 metros entre as cadeiras odontológicas;

- Utilização de respirador particulado N95/PFF2S ou equivalente;

- Uso de protetor facial (face shield);

- Atendimento de um paciente por turno;

- Fazer a sucção constante da saliva, sempre que possível utilizando bomba à vácuo, e realizar o atendimento a quatro mãos;

- Evitar o uso de seringa tríplice e, quando necessário, não utilizar ar/água ao mesmo tempo (forma de spray);

- Preferir secar com algodão ou gaze;

- Uso de isolamento absoluto sempre que possível;

- Evitar utilizar turbinas de alta e baixa rotação sem sistema antirrefluxo;

- Usar o mínimo possível a caneta de alta rotação, preferir utilizar contra-ângulo e escavadores de dentina e, se necessário seu uso, regular o fluxo de água e ar ao mínimo necessário;

- Não utilizar ultrassom e jato de bicarbonato. Utilizar sempre que possível curetas periodontais;

- Preferir a realização de radiografias extraorais para reduzir o estímulo à salivação e a tosse;

- Não utilizar a cuspideira;

- Preferir técnicas químico-mecânicas no tecido acometido em casos de pulpite irreversível sintomática, utilizando isolamento absoluto e aspiração contínua;

- O enxágue de feridas cirúrgicas deve ser realizado lentamente para evitar pulverização;

- Odontopediatria: preferir medidas preventivas não invasivas ou minimamente invasivas (vide Anexo 14.3 - p. 85);

- A adoção de outras medidas e dispositivos que promovam a circulação do ar ou a redução das partículas em suspensão é recomendável, desde que avaliadas junto a profissional habilitado, que estejam de acordo com a legislação e que as normas técnicas vigentes e os dispositivos tenham registro na ANVISA. 
O Quadro 3 apresenta uma proposta para o retorno dos atendimentos eletivos nas diferentes especialidades, baseada no risco relativo de contaminação em relação à proximidade durante $o$ atendimento, ao tempo de contato próximo com o paciente e à probabilidade de produção de aerossol.

Quadro 3. Graduação do nível de risco relativo de contaminação com base na proximidade, no tempo de contato próximo com o paciente e na probabilidade de produção de aerossol para os procedimentos realizados nas diferentes especialidades

\begin{tabular}{|c|c|c|c|}
\hline $\begin{array}{l}\text { Baixo risco de produção } \\
\text { de aerossol } \\
\text { (sem contato próximo) }\end{array}$ & $\begin{array}{l}\text { Baixo risco de produção } \\
\text { de aerossol } \\
\text { (mínimo contato } \\
\text { próximo, sem aerossol, } \\
\text { sem uso do spray da } \\
\text { seringa tríplice) }\end{array}$ & $\begin{array}{l}\text { Moderado/alto risco de } \\
\text { produção } \\
\text { de aerossol } \\
\text { (contato próximo, com } \\
\text { aerossol, porém aerossol } \\
\text { controlado) }\end{array}$ & $\begin{array}{l}\text { Alto risco de produção } \\
\text { de aerossol } \\
\text { (contato próximo, com } \\
\text { aerossol, difícil controle } \\
\text { do aerossol) }\end{array}$ \\
\hline $\begin{array}{l}\text { Diagnóstico: } \\
\text { radiografias panorâmica, } \\
\text { cefalométrica e } \\
\text { outras extraorais, } \\
\text { Teleodontologia }\end{array}$ & $\begin{array}{l}\text { Diagnóstico: exame } \\
\text { clínico, radiografias } \\
\text { intraorais }\end{array}$ & $\begin{array}{l}\text { Prevenção: polimento bem } \\
\text { controlado com o mínimo de } \\
\text { pasta profilática, aplicação } \\
\text { de selante utilizando } \\
\text { isolamento absoluto }\end{array}$ & $\begin{array}{l}\text { Dentística: uso de } \\
\text { alta rotação ou spray } \\
\text { de água/ar, sem } \\
\text { isolamento absoluto }\end{array}$ \\
\hline \multirow[t]{6}{*}{$\begin{array}{l}\text { Prevenção: instruções } \\
\text { de higiene oral e de } \\
\text { dieta }\end{array}$} & $\begin{array}{l}\text { Prevenção: aplicação de } \\
\text { flúor, incluindo diamino } \\
\text { fluoreto de prata, } \\
\text { tratamento restaurador } \\
\text { atraumático }\end{array}$ & $\begin{array}{l}\text { Dentística: restaurações } \\
\text { utilizando isolamento } \\
\text { absoluto }\end{array}$ & $\begin{array}{l}\text { Endodontia: } \\
\text { procedimentos } \\
\text { com aerossol sem } \\
\text { isolamento absoluto }\end{array}$ \\
\hline & $\begin{array}{l}\text { Dentística: diamino } \\
\text { fluoreto de prata para } \\
\text { cáries, restauração } \\
\text { atraumática ou } \\
\text { terapêutica }\end{array}$ & $\begin{array}{l}\text { Endodontia: procedimentos } \\
\text { endodônticos utilizando } \\
\text { isolamento absoluto }\end{array}$ & $\begin{array}{l}\text { Periodontia: raspagem } \\
\text { utilizando ultrassom e } \\
\text { jato de bicarbonato }\end{array}$ \\
\hline & $\begin{array}{l}\text { Cirurgia oral: extração } \\
\text { simples }\end{array}$ & $\begin{array}{l}\text { Periodontia: raspagem } \\
\text { manual }\end{array}$ & $\begin{array}{l}\text { Prótese removível: } \\
\text { preparos dentais }\end{array}$ \\
\hline & $\begin{array}{l}\text { Ortodontia: } \\
\text { ajuste de aparelhos }\end{array}$ & $\begin{array}{l}\text { Prótese removível: } \\
\text { procedimentos sem a } \\
\text { necessidade de ajustes } \\
\text { intraorais, por exemplo, } \\
\text { de oclusão. Todos ajustes } \\
\text { extraorais realizados após } \\
\text { desinfecção das peças }\end{array}$ & $\begin{array}{l}\text { Prótese fixa: preparos } \\
\text { dentais sem isolamento } \\
\text { absoluto }\end{array}$ \\
\hline & & $\begin{array}{l}\text { Prótese fixa: preparos } \\
\text { utilizando isolamento } \\
\text { absoluto, inserção e } \\
\text { cimentação de próteses } \\
\text { com ajustes feitos } \\
\text { extraoralmente após } \\
\text { desinfecção }\end{array}$ & $\begin{array}{l}\text { Cirurgia oral: cirurgias } \\
\text { orais complexas }\end{array}$ \\
\hline & & $\begin{array}{l}\text { Ortodontia: uso mínimo } \\
\text { das turbinas, com produção } \\
\text { mínima de aerossol }\end{array}$ & $\begin{array}{l}\text { Ortodontia: } \\
\text { procedimentos com } \\
\text { produção de aerossol }\end{array}$ \\
\hline
\end{tabular}

Fonte: ILLINOIS DEPARTMENT OF PUBLIC HEALTH. Revised interim guidance: provision of routine oral and dental care. Version number 2.0, May 2020. Disponível em: https://www.dph.illinois.gov/ covid19/community-guidance/routine-oral-and-dental-care. Acesso em: 11 jun. 2020.. 


\section{CUIDADOS AO FINAL DO ATENDIMENTO DE PACIENTES}

No final do tópico 11 deste manual (p. 67), há instruções para a realização da desparamentação, por meio da remoção cuidadosa de cada EPI, visando reduzir os riscos de contaminação.

\section{Pacientes}

- Remover o babador com o mínimo de agitação e manuseio;

- Pedir para o paciente higienizar as mãos com álcool em gel 70\%;

- Solicitar que o paciente coloque imediatamente a outra máscara caseira limpa que levou para a consulta, conforme orientações pré-consulta;

- Retirar o avental com o mínimo de agitação e manuseio e os propés;

- Pedir para que o paciente higienize as mãos;

- Fora da área clínica, solicitar que o paciente retire o gorro e os óculos de proteção;

- Assinar documentos, receber orientações, receita, atestado, etc.;

- Na saída da clínica, solicitar que o paciente realize nova higienização alcoólica das mãos. 


\section{Alunos auxiliares}

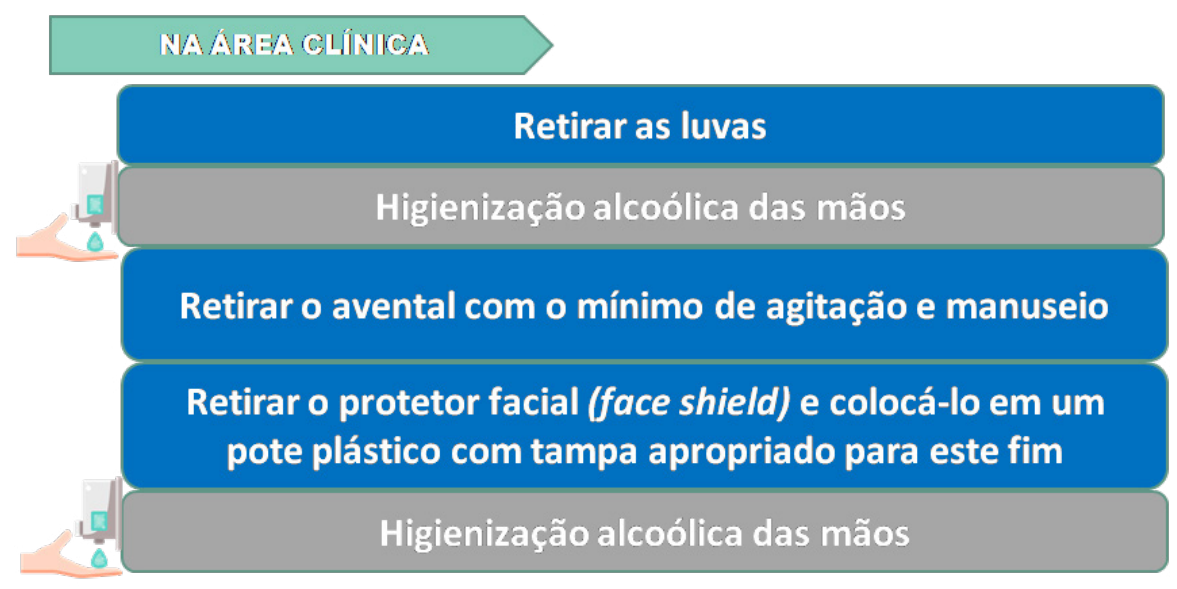

FORA DJAAREA CLIINIIICA

Preencher fichas, receituário, atestado, etc. com sobreluvas

\section{Dispensar o paciente}

Retirar os sapatos profissionais e vestir os de uso externo

Higienização alcoólica das mãos

Retirar-se do ambiente clínico e aguardar o tempo de redução do aerossol 


\section{Operadores}

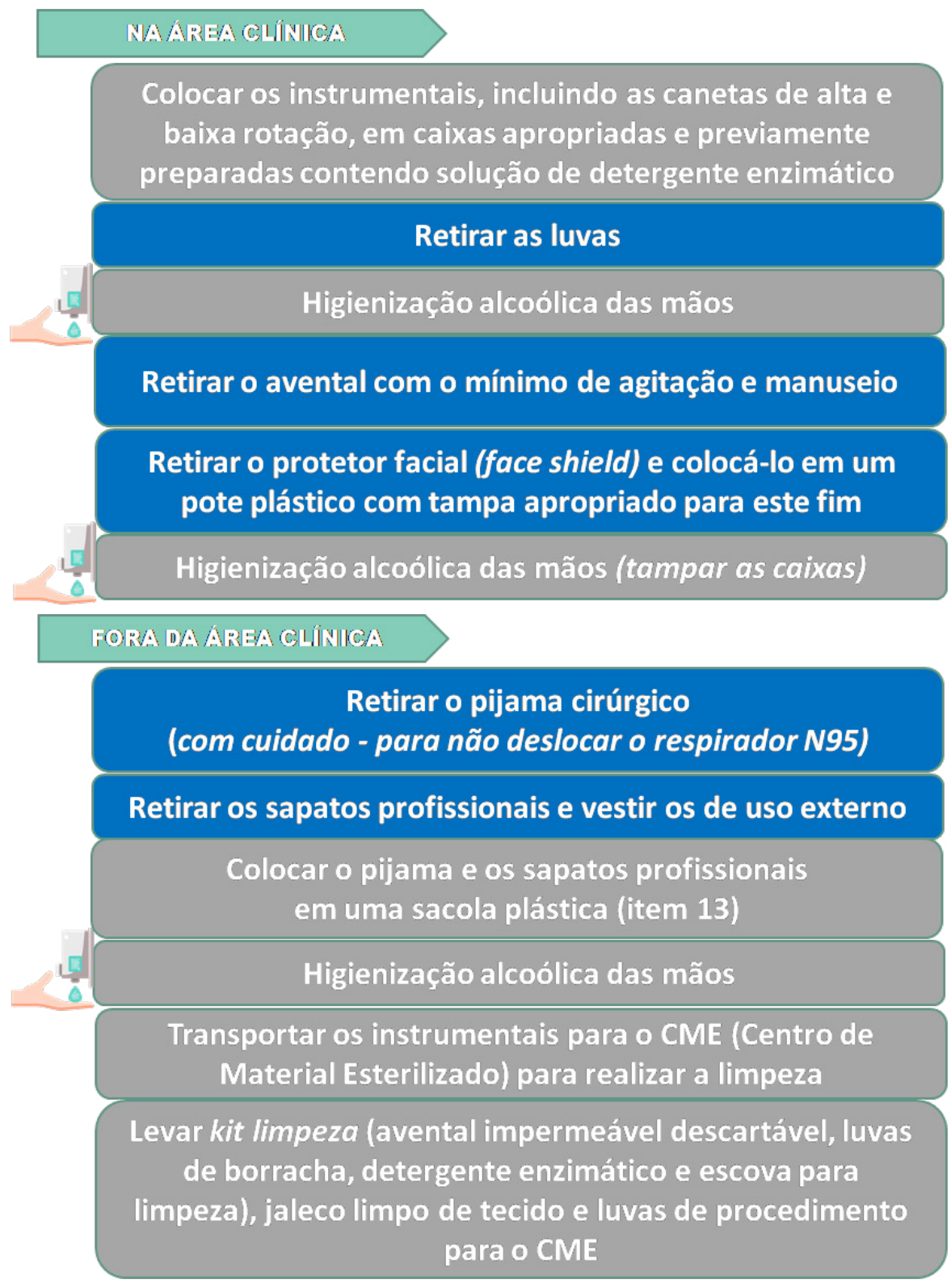




\section{Professores e técnicos}

\section{NAAREA CLLININICA}

\section{Retirar as luvas, se estiver utilizando}

Higienização alcoólica das mãos

Retirar o avental com o mínimo de agitação e manuseio

Retirar o protetor facial (face shield) e colocá-lo em um pote plástico com tampa apropriado para este fim

Higienização alcoólica das mãos

FORA DAARIEA CLINNIICA

Prof.: assinar fichas, receituário, atestado, etc, com sobreluvas

Retirar os sapatos profissionais e vestir os de uso externo

Higienização alcoólica das mãos

Retirar-se do ambiente clínico e aguardar o tempo de redução do aerossol

IMPORTANTE: A CCIO recomenda que um professor em cada clínica, em sistema de rodízio, permaneça durante o tempo de redução do aerossol após o término da clínica para acompanhar os acadêmicos AUXILIARES na limpeza e na desinfecção final de seus boxes. Esse professor deve desparamentar-se conforme as instruções acima; os demais realizarão a desparamentação final seguindo instruções contidas nas p. 56 e 57. 


\section{PROTOCOLO DE LIMPEZA E ESTERILIZAÇÃO DA UEPG}

Procedimentos a serem realizados com os materiais utilizados durante o atendimento, ou mesmo com aqueles materiais que não foram utilizados, mas sofreram algum tipo de contaminação.

OBSERVAÇÃO: Após cada atendimento, realizar a limpeza e a esterilização do kit acadêmico (alta e baixa rotação, contra-ângulo e peça reta). Lavar com água e sabão e embalar para esterilização.

AMBIENTE (CME): Deve haver marcações no chão para a fila de retirada e entrega de material, de modo a manter o distanciamento social nos horários previamente estabelecidos.

\section{Em clínica}

Após o procedimento realizado nas clínicas, os materiais utilizados e/ou contaminados deverão ser armazenados em uma caixa de "material contaminado" (disponíveis nas clínicas e identificadas). Essa caixa plástica deve conter água da torneira e detergente enzimático (providenciado pelo acadêmico).

\section{Clínica $\rightarrow$ expurgo}

Descer até o expurgo de gorro, óculos de proteção e respirador N95 assim que acabar o atendimento em clínica (OPERADOR) (o material deve ser lavado IMEDIATAMENTE após o uso, não sendo permitido guardá-lo em armários, salas ou carros para ser limpo algumas horas ou dias depois). Para a limpeza dos materiais, o acadêmico deve possuir seu próprio "kit limpeza" (avental impermeável descartável, luvas de borracha de cano alto de cor diferente das utilizadas em clínica, detergente enzimático e escova para limpeza do material). 
OBSERVAÇÃO: Na falta de EPIs, a CCIO permite o uso de avental em PVC impermeável reutilizável (lavável), desde que sejam tomados todos os cuidados para seu processamento, mencionados no tópico 13 deste manual (p. 70).

\section{No expurgo}

Vestir um avental de manga longa impermeável descartável (plástico ou de TNT) ou, como segunda opção, um avental de PVC impermeável lavável, ambos apropriados para esse ambiente; calçar as luvas de borracha de cano alto, retirar o material sujo da caixa de material contaminado e colocá-lo em uma cuba ultrassônica (utilizá-la conforme instruções). Na falta da cuba ultrassônica, lavar o material submerso em recipiente com água (não utilizar água corrente para não haver formação de gotículas) com escova e detergente enzimático, esfregando bem. Utilizar as lupas que estão disponíveis no expurgo e empacotamento para a inspeção dos materiais lavados. Após o uso da lupa, fazer sua desinfecção. Na presença de alguma sujidade nos instrumentais, repetir o ciclo de lavagem na cuba ultrassônica ou manualmente, ou, ainda, se necessário, descartar e substituir o material se ele não estiver em ótimo estado (o material tem seu tempo de validade e de uso, devendo ser descartado e substituído quando o aluno, o professor ou a enfermeira julgar necessário).

\section{Expurgo $\rightarrow$ empacotamento}

Terminado o tempo de limpeza na cuba ultrassônica, retirar o material e enxaguá-lo em recipiente com água (não utilizar água corrente para não haver formação de gotículas). O material deve, então, ser colocado em uma caixa plástica (disponível no expurgo). Retirar e descartar o avental impermeável ou acondicionar o avental reutilizável em saco plástico limpo para processamento em casa. Fazer a higienização com água e sabão das luvas de borracha e, na sequência, sua desinfecção (p. 59). Retirá-las cuidadosamente e acondicioná-las em um saco plástico limpo. Realizar a higienização 
alcoólica das mãos. Em seguida, a caixa plástica contendo o material limpo deve ser levada até a área de empacotamento por meio das janelas (óculos) entre as duas áreas (expurgo - empacotamento).

\section{No empacotamento}

Entrar utilizando gorro, respirador N95 e óculos de proteção. Vestir um jaleco de tecido limpo de mangas longas (uso individual), calçar luvas de procedimento e secar o material, utilizando toalhas de papel absorvente descartáveis disponíveis no Empacotamento. O material deve ficar completamente seco, a fim de garantir um procedimento adequado de esterilização. Empacotar o material com papel grau cirúrgico, retirando o ar do pacote para, somente então, selar as bordas (no caso de caixas metálicas ou materiais mais pesados, selar os quatro lados para evitar a abertura dos pacotes). A faixa de selagem deve ser ampla e reforçada. Recomenda-se deixar uma borda de aproximadamente $3 \mathrm{~cm}$, a fim de facilitar a abertura asséptica do pacote. Para os materiais utilizados em procedimentos mais invasivos, como os procedimentos cirúrgicos, deve-se colocar junto ao material um indicador químico de classe 3 (disponível no $\mathrm{CME}$ ), para garantir sua esterilidade. Pinças e tesouras devem ser colocadas com suas articulações abertas. O papel grau cirúrgico é de uso único, devendo ser descartado logo após o uso. Após terminar o empacotamento, os materiais devem ser levados ao funcionário do CME (por meio das janelas ou dos óculos presentes entre as áreas de empacotamento e esterilização).

OBSERVAÇÃO: Os materiais que deverão ser desinfetados com álcool 70\% ou ácido peracético 0,2\% devem ser friccionados após ter sido lavados e secados (na área de EXPURGO) (p. 36). Os materiais devem então ser colocados em um saco plástico (providenciado pelo acadêmico) e levados até o funcionário do CME (por meio das janelas presentes entre as áreas de empacotamento e esterilização). Os funcionários deverão colar a fita indicando a data da desinfecção. Essa técnica deve ser realizada apenas em artigos específicos que não são passíveis de esterilização. 


\section{$\mathrm{Na}$ área de esterilização}

Informações como senha do acadêmico, número de pacotes deixados para ser esterilizados, qual autoclave foi utilizada e o lote que vai ser esterilizado, além da data da esterilização, devem ser marcadas em uma fita zebrada anexada ao pacote contendo os materiais a serem esterilizados. Essa fita também serve como indicador químico que demonstra se o pacote passou pelo processo de esterilização. 0 aluno deve assinar um recibo, que deverá ser apresentado no momento da retirada do material do CME.

\section{Armazenamento}

$\mathrm{O}$ armazenamento dos materiais deve ser realizado no CME. $O$ acadêmico deve retirar apenas o kit que utilizará na disciplina. Para retirar o material, o acadêmico deve levar uma caixa plástica específica para material ESTÉRIL (não podendo utilizá-la para outros fins. A caixa deve estar devidamente identificada com a inscrição "MATERIAL ESTERILIZADO"), que precisa estar limpa e em boas condições de uso. Essa caixa deve ser utilizada apenas para o transporte de material estéril. Não devem ser utilizadas caixas de transporte para esse fim. Sem a caixa e sem o recibo (entregue ao acadêmico no momento em que o material foi deixado para esterilização), o material do CME não poderá ser retirado ou transportado. 0 material retirado do CME deve ser levado diretamente até a clínica onde será utilizado. A caixa do material estéril deve ficar bem fechada e bem guardada, evitando sol e calor excessivo, preferencialmente no armário do acadêmico. Após a retirada do material do CME, este tem validade de apenas 1 dia. $O$ material armazenado no CME tem validade de 30 dias. 


\section{Esterilização}

É o processo que visa destruir ou eliminar todas as formas de vida microbiana presentes. Para garantir a esterilização, o fluxo deve compreender as seguintes etapas: Lavagem, Empacotamento e Esterilização. Caso o aluno lave o material e o armazene em outro local, uma nova lavagem deve ser feita antes da esterilização, obedecendo ao fluxo para garantir um processo de esterilização adequado. Na UEPG, o método de processamento é o da autoclave pré-vácuo. Testes diários são realizados para comprovar que as máquinas estão funcionando adequadamente; isso inclui o teste biológico, que mostra crescimento bacteriano ou não.

\section{Funcionários do CME}

- Devem utilizar EPIs completos: respirador N95/PFF2S ou similar sem válvula, pijama cirúrgico, calçado emborrachado e fechado com meias grossas, gorro/touca descartável impermeável, óculos de proteção, protetor facial e avental impermeável e descartável de gramatura $50 \mathrm{~g} / \mathrm{m}^{2}$;

- Devem seguir as instruções descritas no tópico "Paramentação" (p. 29).

OBSERVAÇÃO: Na falta de EPIs, a CCIO permite o uso de avental de PVC impermeável reutilizável (lavável) pelos funcionários do CME, desde que sejam tomados todos os cuidados para seu processamento mencionados no tópico 13 deste manual (p. 70).

\section{Para conhecimento, cabe aos funcionários do CME:}

- Não receber campos operatórios sujos para ser esterilizados;

- Não entregar material estéril sem a presença de caixas ideais para seu acondicionamento; 
- Não esterilizar materiais embalados em papel grau cirúrgico previamente utilizado (pois isso impede a esterilização adequada do instrumental);

- Registrar todas as irregularidades cometidas por acadêmicos no CME.

\section{Alerta aos acadêmicos}

Os procedimentos de limpeza, desinfecção e esterilização de superfícies e instrumentais odontológicos deverão ser corretamente realizados, obedecendo ao fluxo unidirecional. Caso os acadêmicos não realizem esses procedimentos das formas estabelecidas no presente manual, as irregularidades serão levadas à CCIO e ao Colegiado de Odontologia, a fim de que as medidas adequadas para cada situação sejam tomadas. Lembre-se: a não realização ou a realização de forma incorreta dos procedimentos citados anteriormente expõe os pacientes e toda a equipe odontológica a riscos que podem ser irreversíveis. 


\section{LIMPEZA E DESINFECÇÃO TERMINAL DAS CLÍNICAS}

\section{Técnicos, alunos auxiliares e professores}

Após aguardar o tempo de redução do aerossol*, retornar à clínica e realizar a desinfecção final dos equipamentos e superfícies (janelas da clínica devem ter sido mantidas abertas, e a porta, fechada), lembrando que o aluno AUXILIAR, o professor responsável e o técnico retiraram-se da clínica ainda portando respirador N95, pijama cirúrgico, gorro e óculos de proteção.

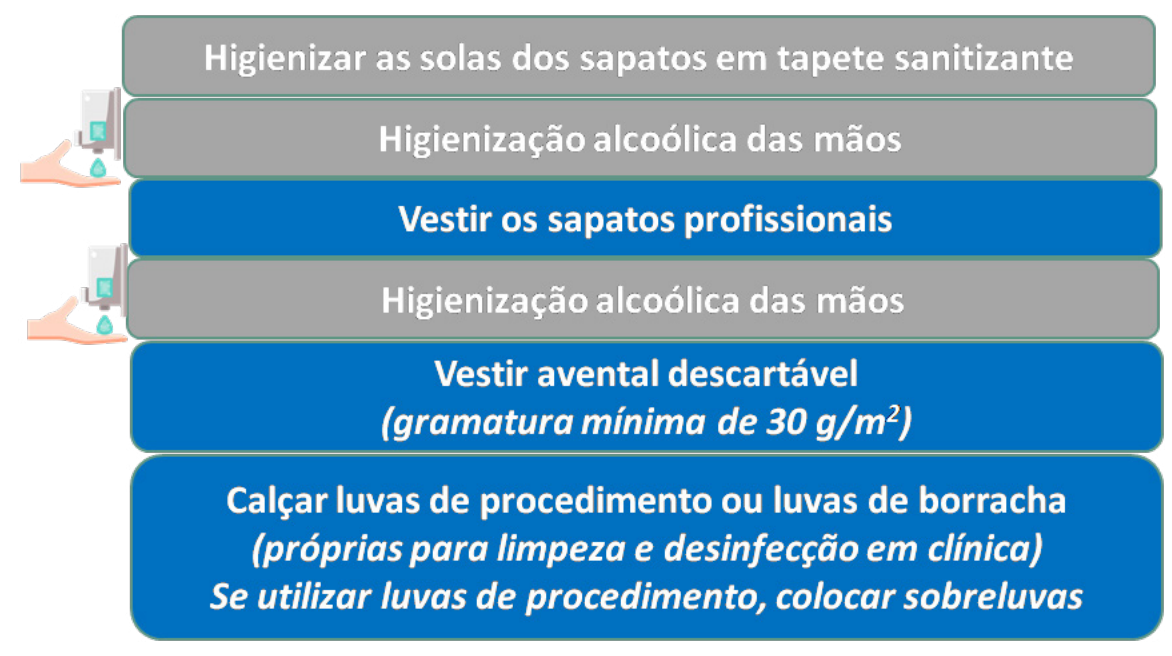

*A ABENO recomenda que o tempo entre o término das atividades clínicas e a entrada para a realização da limpeza e da desinfecção seja planejado considerando o laudo da equipe de Engenharia Clínica/Saúde Ocupacional. A associação sugere, ainda, que o tempo mínimo estabelecido seja de 30 minutos. 


\section{$1^{\circ}$ LIMPEZA E DESINFECÇÃO DAS TUBULAÇÕES DOS EQUIPOS - TÉCNICOS}

- Higienizar corretamente as mãos;

- Calçar luvas de borracha;

- Retirar os reservatórios de água das conexões dos equipos;

- Lavar os reservatórios com água, detergente líquido e escova para frascos, enxaguá-los e secá-los (de preferência, utilizar recipiente com água para lavagem e evitar utilizar a torneira - água corrente);

- Colocar 100 mL de solução de ácido peracético a 1\% nos reservatórios de água e rosquear novamente as conexões dos equipos;

- À medida que a solução for sendo lavada e colocada em cada reservatório, solicitar a entrada do aluno AUXILIAR respectivo e pedir a ele que pressione o pedal do equipo, acionando as conexões das peças de mão e a seringa tríplice dentro de um saco plástico até acabar com a solução que está no frasco. Em seguida, aspirar a solução de dentro do saco.

\section{$2^{\circ}$ LIMPEZA E DESINFECÇÃO DAS MESAS, BOXES E BANCADAS - ALUNOS AUXILIARES}

- Remover as barreiras físicas e descartá-las em lixeiras com acionamento a pedal contendo saco plástico vermelho ou, se não houver, branco leitoso com indicação de material infectante;

- Se estiver utilizando luvas de procedimento, elas devem ser trocadas nesse momento e se estiver utilizando luvas de borracha, fazer a desinfecção sempre que necessário;

- Acionar as conexões das peças de mão (alta e baixa rotação) e a seringa tríplice, ou o botão de sistema de assepsia da tubulação até acabar com a solução que está no frasco (ácido peracético 
adicionado pelos técnicos das clínicas). Acionar em um saco plástico e depois aspirar o conteúdo;

- Se estiver utilizando luvas de procedimento, elas devem ser trocadas nesse momento e se estiver utilizando luvas de borracha, fazer a desinfecção sempre que necessário;

- Realizar a limpeza e a desinfecção de mesas, boxes e bancadas, evitando o contato com as superfícies sob elas. Em caso de contato com as superfícies, realizar também a limpeza e a desinfecção dessas áreas. Executar a limpeza e desinfecção final (p.36), deixando o box limpo e organizado;

- Iniciar a desinfecção da área menos contaminada para a mais contaminada, de cima para baixo, de dentro para fora:

1. Alça do refletor;

2. Cadeira odontológica (estofado);

3. Mocho;

4. Superfície da unidade/carrinho auxiliar;

5. Equipamentos de alta e baixa rotação, seringa tríplice, sugadores e cuspideiras;

6. Protetor facial e óculos de proteção (operador, paciente e acompanhante).

- Descarte de material perfurocortante: agulhas para anestesia e para sutura, lâminas de bisturi e demais materiais perfurocortantes devem ser descartados em recipiente apropriado e devidamente identificado. Todos os cuidados devem ser tomados para evitar qualquer tipo de acidente no momento do descarte;

- Executar a desparamentação;

- Retornar para casa seguindo as recomendações do item 12 deste protocolo geral (p.69). 


\section{Desparamentação - professores e alunos auxiliares}

IMPORTANTE: Conforme mencionado na p. 46, a CCIO recomenda que um professor em cada clínica, em sistema de rodízio, permaneça após o período de redução do aerossol ao término da clínica para acompanhar os acadêmicos AUXILIARES na limpeza e na desinfecção final de seus boxes.

\section{NAARIEA CLIINIICA}

\section{Retirar as luvas - se estiver usando luvas de borracha $\rightarrow$} lavar com água e sabão e desinfetar (p. 59)

Higienização alcoólica das mãos
Retirar o avental pelo avesso
Retirar o protetor facial, se ainda estiver utilizando, e de agitação e manuseio
colocá-lo em um pote plástico com tampa apropriado para
este fim

FORA DAARAEA CLIINIICA

Retirar o gorro

Retirar os óculos de proteção

Calçar novas luvas de procedimento e realizar a limpeza e desinfecção do face shield e dos óculos de proteção

(paciente e acompanhante também). Armazená-los em sacos plásticos apropriados. Retirar e descartar as luvas de procedimento

Higienização alcoólica das mãos

Retirar o respirador N95/PFF2S ou similar, armazenar adequadamente para reuso ou descartar 
FORA DAARAA CLIINIICA

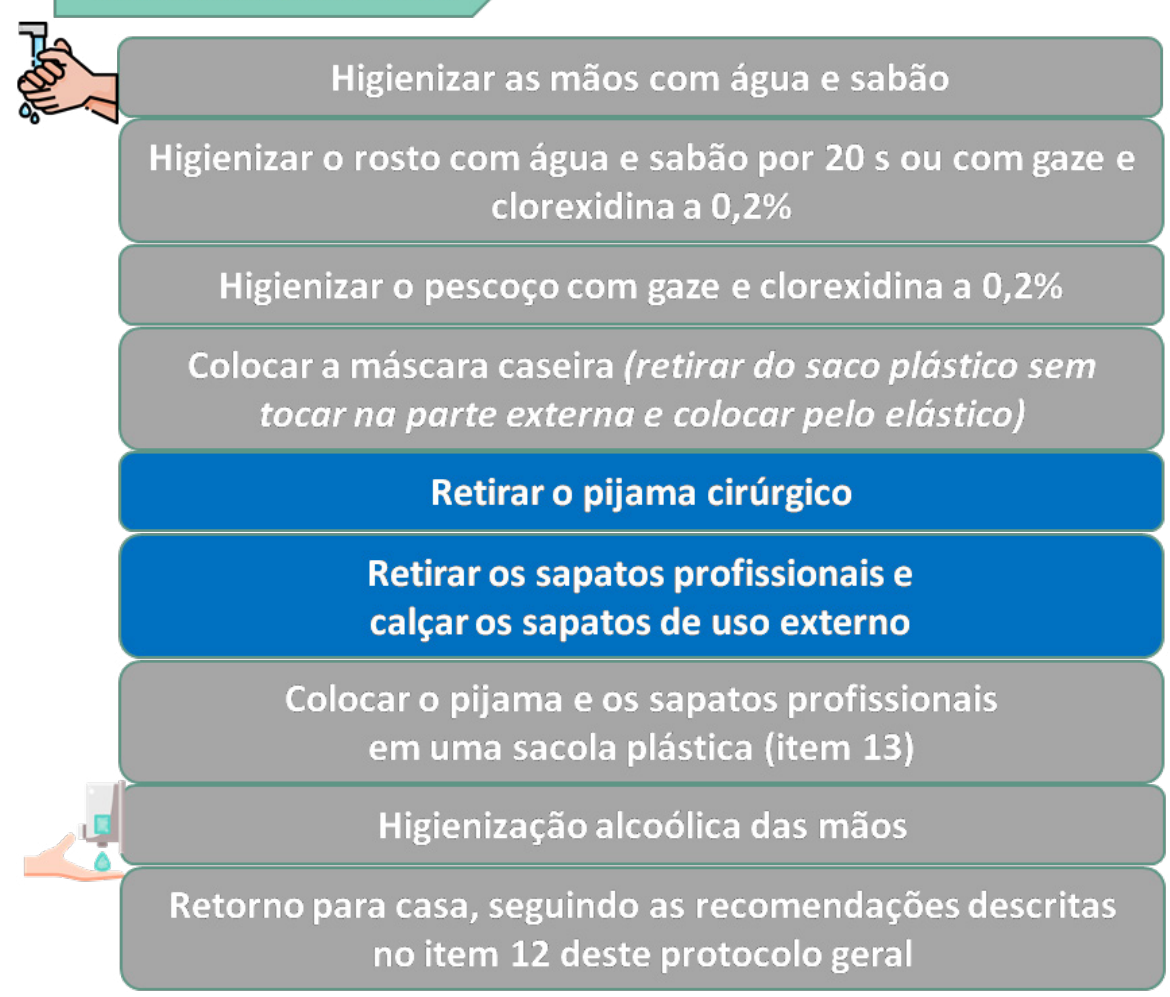




\section{Desparamentação - operadores}

OBSERVAÇÃO: os alunos OPERADORES que finalizaram o processamento de seu material no CME devem retornar à clínica e realizar sua desparamentação final:

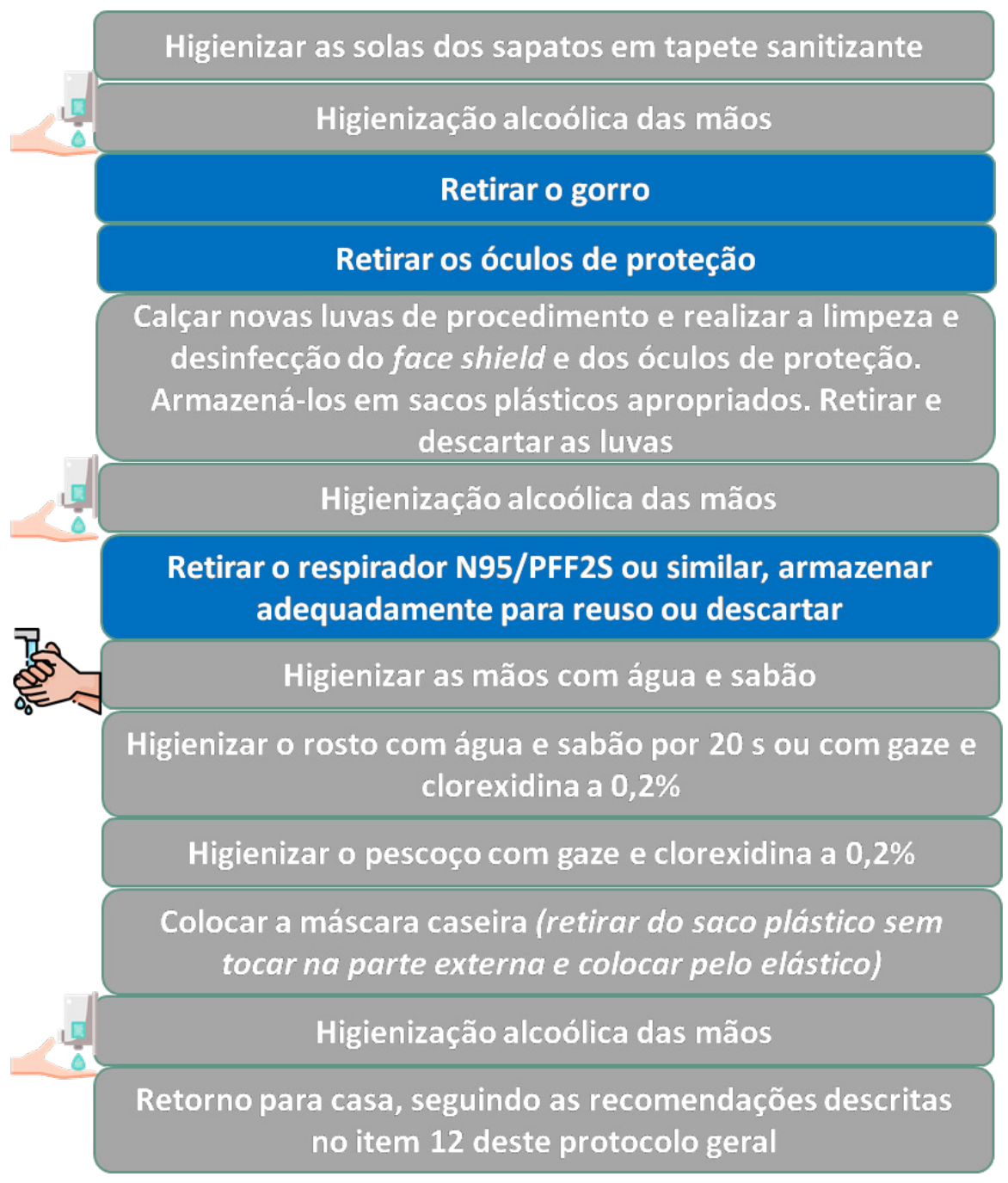




\section{Como lavar as luvas de borracha:}

- Antes de retirar as luvas de borracha, lavar a parte externa com água e sabão;

- Enxaguar em água corrente;

- Secar com papel toalha ou com panos descartáveis;

- Aplicar o agente desinfetante conforme o Quadro 2 (p. 36);

- Retirar a luva da mão direita, puxando-a pelos dedos com a mão esquerda;

- Retirar a luva da mão esquerda, introduzindo os dedos da mão direita desenluvada pela parte de dentro dela, sem encostar na parte externa;

- Verificar se existe a presença de furos ou rasgos, se sim, descartá-la;

- Armazenar as luvas de borracha em sacos plásticos limpos e hermeticamente fechados. 


\section{$3^{\circ}$ LIMPEZA E DESINFECÇÃO FINAL DOS EQUIPOS E DOS ARTIGOS E MATERIAIS DE CONSUMO UTILIZADOS DURANTE A AULA CLÍNICA - TÉCNICOS}

- Após a desinfecção de cada box pelos alunos OPERADORES, os equipos devem ser limpos com água e sabão e, posteriormente, desinfetados com hipoclorito de sódio a 1\% (Quadro 2 - p. 36);

- Lavar as luvas de borracha (com água e sabão) antes de retirá-las e fazer a desinfecção (p. 59) conforme o Quadro 2 (p. 36);

- Fazer a higienização alcoólica das mãos;

- Calçar luvas de procedimento;

- Todos os materiais de consumo utilizados durante a aula clínica devem ser desinfetados de acordo com o Quadro 2 (p.36), seguindo as especificações de cada agente de desinfecção;

- Executar a desparamentação parcial para o manejo dos resíduos (p.61);

- Fazer o manejo dos resíduos da clínica, conforme instruções a seguir (p. 62);

- Prosseguir para a desparamentação final (p. 63);

- Registrar o procedimento de limpeza e desinfecção das tubulações dos equipos em formulário apropriado - após desparamentação (deixar os documentos no Departamento de Odontologia para fazer os registros fora do ambiente clínico);

- Retorno para casa, seguindo as recomendações do item 12 deste protocolo geral (p. 69). 


\section{Desparamentação - técnicos (manejo dos resíduos)}

\begin{tabular}{|c|}
\hline Higienização alcoólica das mãos enluvadas \\
\hline $\begin{array}{l}\text { Retirar o avental pelo avesso } \\
\text { com o mínimo de agitação e manuseio }\end{array}$ \\
\hline Higienização alcoólica das mãos enluvadas \\
\hline Fechar os sacos de material infectante \\
\hline Retirar as luvas e colocá-las sobre um papel toalha \\
\hline Higienização alcoólica das mãos \\
\hline Colocar um novo saco de material infectante na lixeira \\
\hline Higienização alcoólica das mãos \\
\hline $\begin{array}{l}\text { Retirar o protetor facial, se ainda estiver utilizando, e } \\
\text { colocá-lo em um pote plástico com tampa apropriado para } \\
\text { este fim }\end{array}$ \\
\hline Higienização alcoólica das mãos \\
\hline $\begin{array}{c}\text { Retirar o pijama cirúrgico } \\
\text { (com cuidado - para não deslocar o respirador N95) }\end{array}$ \\
\hline $\begin{array}{l}\text { Retirar os sapatos profissionais e } \\
\text { calçar os sapatos de uso externo }\end{array}$ \\
\hline $\begin{array}{c}\text { Colocar o pijama e os sapatos profissionais } \\
\text { em uma sacola plástica (item 13) }\end{array}$ \\
\hline Higienização alcoólica das mãos \\
\hline Vestir um novo avental impermeável descartável $\left(30 \mathrm{~g} / \mathrm{m}^{2}\right)$ \\
\hline Calçar um novo par de luvas de procedimento \\
\hline
\end{tabular}




\section{$4^{\circ}$ MANEJO DOS RESÍDUOS - TÉCNICOS}

- O vírus SARS-Cov-2 pode ser enquadrado como agente biológico classe de risco 3, seguindo a Classificação de Risco dos Agentes Biológicos publicada em 2017 pelo Ministério da Saúde, e sua transmissão é de alto risco individual e de moderado risco para a comunidade. Assim, todos os resíduos provenientes da assistência a pacientes suspeitos ou confirmados de infecção pelo novo coronavírus devem ser enquadrados na categoria A1,

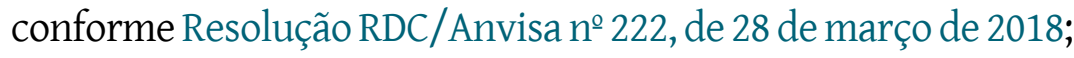

- Categoria A1: resíduos acondicionados em sacos vermelhos, os quais devem ser substituídos sempre que atingirem $2 / 3$ da capacidade ou pelo menos $1 \mathrm{x}$ a cada 48 horas, independentemente do volume e identificados pelo símbolo de substância infectante. Os sacos devem ser contidos em recipientes laváveis, resistentes e com tampa com abertura sem contato manual e com cantos arredondados. Esses resíduos devem ser tratados antes da disposição final ambientalmente adequada;

- Ainda que a RDC no 222/2018 defina que os resíduos provenientes da assistência a pacientes com COVID-19 devam ser acondicionados em sacos vermelhos, EXCEPCIONALMENTE, durante essa fase de atendimento aos pacientes suspeitos ou confirmados de infecção pelo novo coronavírus, caso o serviço de saúde não tenha sacos vermelhos para atender à demanda, poderão ser utilizados os sacos brancos leitosos com o símbolo de infectante para acondicionar esses resíduos. (BRASIL. MINISTÉRIO DA SAÚDE, 2018);

- Ao final das atividades clínicas, o funcionário responsável pelo manejo dos resíduos, ainda paramentado com respirador N95, óculos de proteção e gorro, deve vestir um avental impermeável descartável novo $(30 \mathrm{~g} / \mathrm{m} 2)$ e calçar luvas de procedimento, para só então fechar os sacos e levá-los para a sala de armazenamento externo (abrigo externo);

- A coleta e o transporte interno dos resíduos devem ser feitos em horários que não coincidam com o maior fluxo de pessoas ou de atividades. 


\section{Desparamentação final - técnicos}

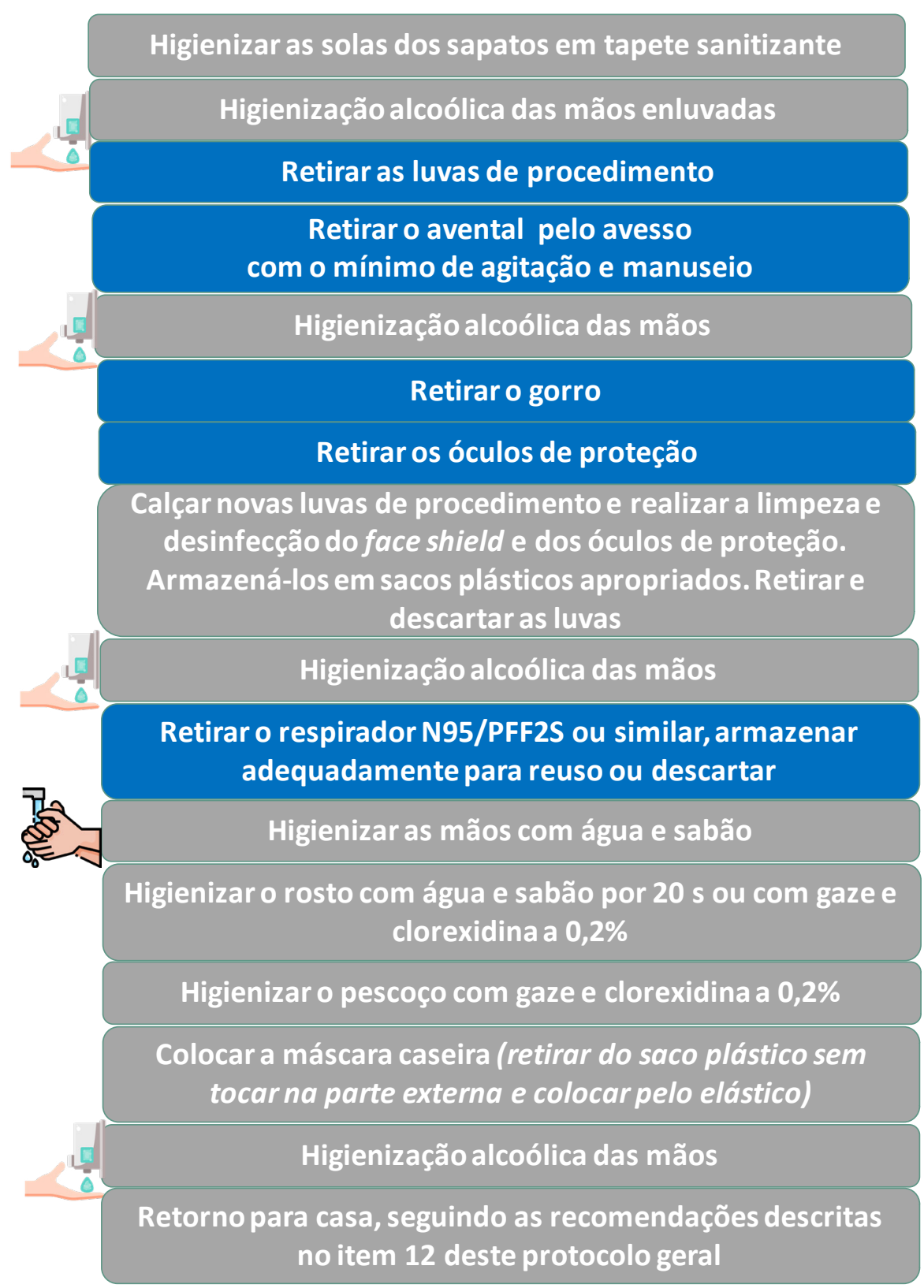




\section{$5^{\circ}$ LIMPEZA DOS PISOS - AUXILIARES DE SERVIÇOS GERAIS}

\section{Procedimentos prévios à limpeza}

1. Higienizar corretamente as mãos;

2. Paramentação, conforme a dos técnicos (p. 25), com acréscimo de alguns pontos:

* Pode-se utilizar máscara cirúrgica com tripla proteção (tipo IIR);

* Botas (material impermeável, cano longo e solado antiderrapante);

* Avental impermeável descartável (gramatura $30 \mathrm{~g} / \mathrm{m}^{2}$ );

* Luvas de borracha com cano longo (ideais para também proteger os antebraços) ou com cano curto;

OBSERVAÇÃO: Na falta de EPIs, a CCIO permite o uso de avental de PVC impermeável reutilizável (lavável), desde que sejam tomados todos os cuidados para seu processamento, os quais constam no tópico 13 deste manual (p. 70).

3. Preparar os materiais a serem utilizados para a limpeza. Os materiais utilizados para a limpeza de pisos devem ser transportados, se possível, em carrinho funcional até o local a ser limpo;

4. Colocar uma placa sinalizadora para evitar acidentes (limpeza de pisos).

\section{Limpeza de pisos e superfícies de todo o ambiente odontológico}

1. Utilizar mops ou enceradeiras;

2. Realizar limpeza úmida do piso, do local menos contaminado para o mais contaminado e do nível mais alto para o mais baixo. Ensaboar, enxaguar e secar. Não usar aspirador de pó (apenas em setores administrativos). Não realizar varredura seca (dispersão de microrganismos); 
3. Ensaboar: fricção com sabão ou detergente (1 balde claro: água; 1 balde escuro: sabão ou detergente). Utilizar mops ou enceradeiras;

4. Enxaguar: remover o sabão ou detergente (balde claro);

5. Secagem do piso: utilizar a torção intensa do mop;

6. Recolher todo o resíduo com o auxílio de uma pá coletora;

7. Desprezar os resíduos recolhidos em lixeira apropriada (lixeira de resíduo comum - saco de lixo preto).

\section{Ao término da limpeza}

1. Lavar as luvas de borracha antes de retirá-las;

2. Higienizar corretamente as mãos;

3. Levar todo o material utilizado para o Depósito de Material de Limpeza (DML).

\section{No depósito de material de limpeza (DML):}

1. Lavar todo o material utilizado;

2. Panos de limpeza de piso e panos de mobília: devem ser encaminhados à lavanderia, preferencialmente, ou lavados manualmente no expurgo;

3. Os discos das enceradeiras devem ser lavados e deixados em suporte para facilitar a secagem;

4. Lavar as luvas de borracha antes de retirá-las e fazer a desinfecção (p. 59) conforme o Quadro 2 (p. 36);

5. Guardar os materiais após lavados e secos.

OBSERVAÇÃo 1: Os equipamentos devem ser limpos ao final de cada jornada de trabalho.

OBSERVAÇÃO 2: Realizar a limpeza do piso das clínicas odontológicas diariamente e nos intervalos entre turnos, ou quando necessário. Não manipular portas com luvas. Limpar diariamente a sala de atendimento, a sala de esterilização e os banheiros. 


\section{Desparamentação no DML - auxiliares de serviços gerais}

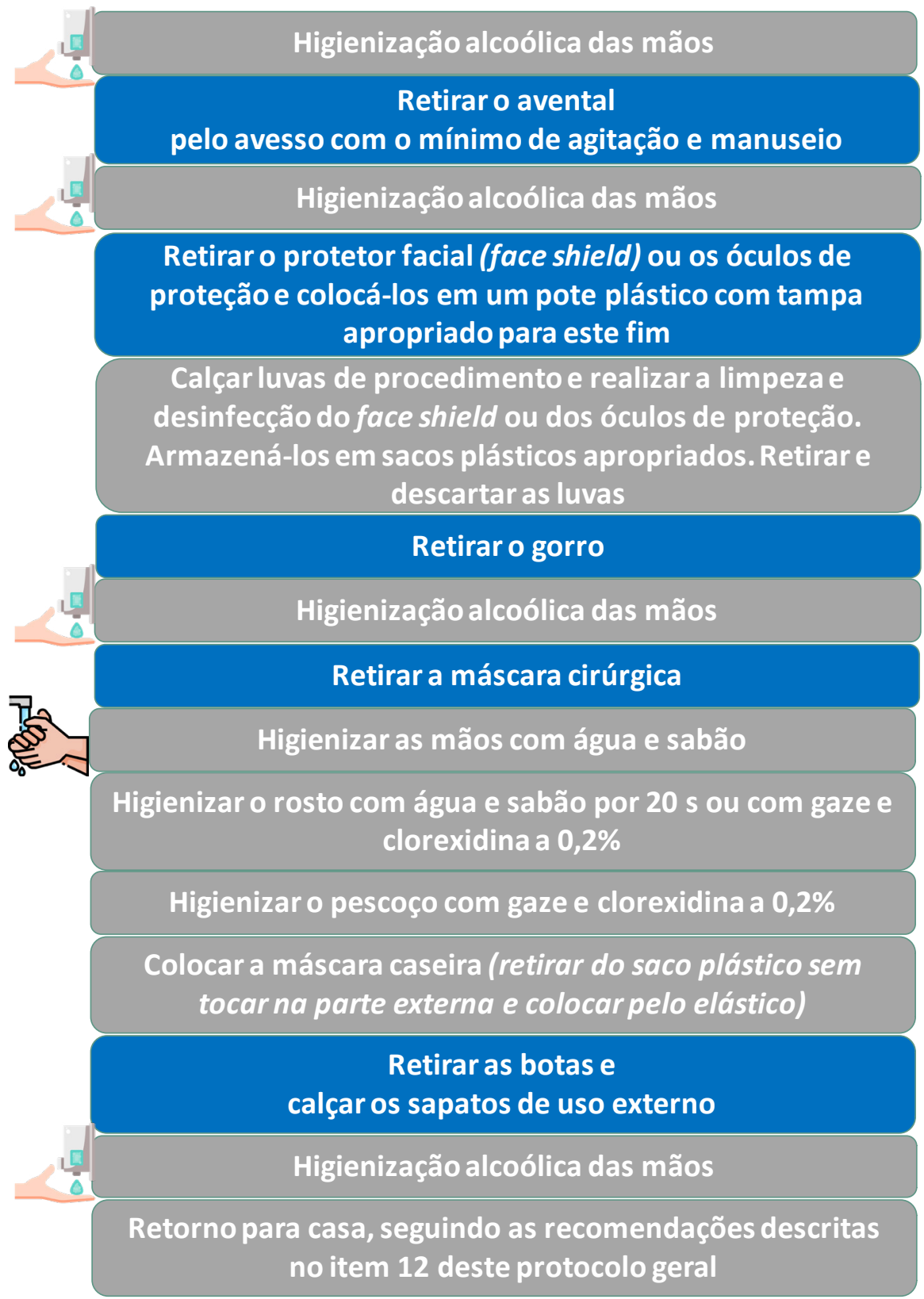




\section{Instruções para a remoção cuidadosa dos EPIs}

Figura 6. Remoção das luvas
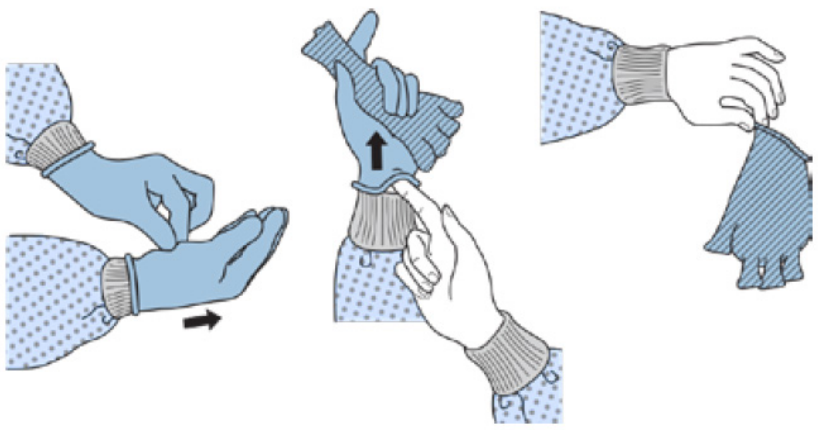

- 1. Com as duas mãos enluvadas, segure a parte externa de uma luva pela parte superior do pulso; 2. Retire a primeira luva, afastando-a do corpo e do pulso até as pontas dos dedos, virando a luva de dentro para fora; 3 . Segure a luva que você acabou de remover em sua mão enluvada; 4. Com a mão sem luva, retire a segunda luva inserindo os dedos dentro da luva na parte superior do pulso; 5. Vire a segunda luva do avesso enquanto a inclina para longe do corpo, deixando a primeira luva dentro da segunda. Descarte as luvas.

Figura 7. Remoção do avental
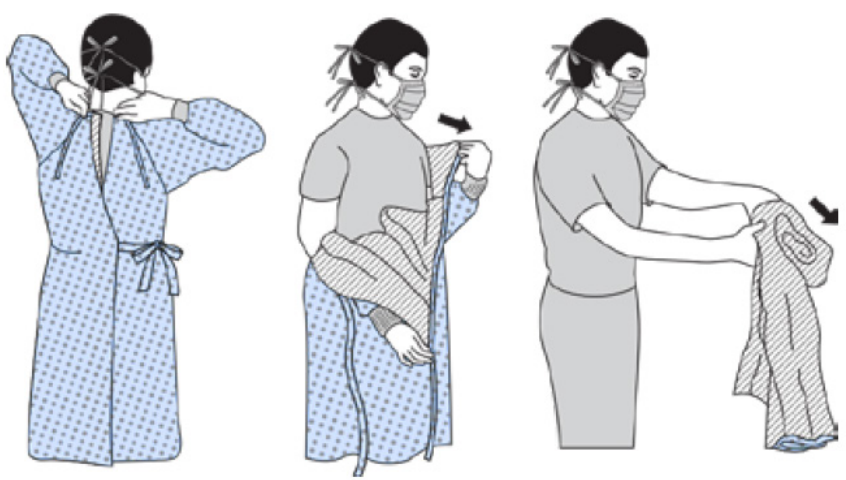

- 1. Abra as tiras e solte as amarras; 2. Empurre o avental pelo pescoço e pelos ombros, tocando apenas em sua parte interna; 3. Retire o avental/capote pelo avesso; 4. Dobre-o ou enrole-o em uma trouxa e descarte o avental. 
Figura 8. Remoção dos óculos ou do protetor facial
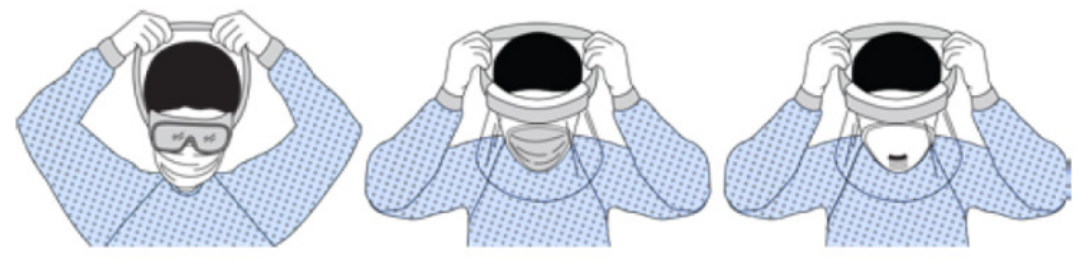

- 1. Remova os óculos ou o protetor pela lateral ou pelas hastes, de trás para a frente, considerando que a parte frontal está contaminada; 2 . Realize a limpeza e desinfecção.

Figura 9. Remoção do gorro ou da touca

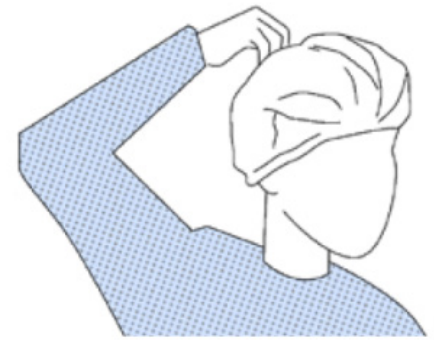

- Puxe o gorro pela parte superior central em um movimento único, sem tocar nos cabelos, e descarte-o.

Fonte Fotos: CONSELHO FEDERAL DE ODONTOLOGIA. Manual de boas práticas em biossegurança para ambientes odontológicos. Rio de Janeiro - RJ. Março de 2020. 42 p. Disponível em: http:// website.cfo.org.br/wp-content/uploads/2020/04/cfo-lanc\%CC\%A7a-Manual-de-Boas-Pra\%CC\%81ticasem-Biosseguranc\%CC\%A7a-para-Ambientes-Odontologicos.pdf. Acesso em: 06 abr. 2020.

Figura 10. Remoção do respirador N95/PFF2S ou similar

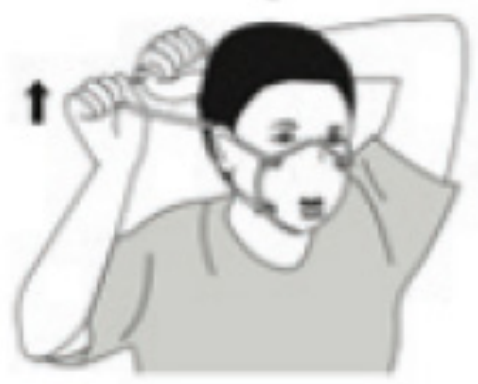

- 1. Segurar o elástico inferior com as duas mãos, passando-o por cima da cabeça para removê-lo; 2. Fazer o mesmo com o elástico superior; 3. Remover o respirador segurando-o pelos elásticos, tomando bastante cuidado para não tocar na superfície interna; 4. Acondicioná-lo para reuso ou descarte.

Fonte Foto: BRASIL. Ministério da Saúde. Agência Nacional de Vigilância Sanitária. Desparamentação de EPIs: cartaz. ANVISA. Disponível em: https://www20.anvisa.gov.br/segurancadopaciente/index.php/ publicacoes/item/desparamentacao-de-epis. Acesso em: 04 jun. 2020. 


\section{ORIENTAÇÕES PARA \\ O RETORNO PARA CASA \\ (PACIENTES, ACADÊMICOS, PROFESSORES E TÉCNICOS)}

- Manter um tapete sanitizante na entrada de casa (pano com solução de água e hipoclorito de sódio - 1 parte de água sanitária e 3 partes de água);

- Retirar os sapatos antes de entrar em casa;

- Higienizar as mãos com água e sabão e/ou preparação alcoólica a $70 \%$;

- Colocar os objetos pessoais que foram levados consigo, como bolsa, carteira, chaves etc., em local previamente preparado para isso (deixar uma caixa na entrada). Esses objetos podem ser higienizados nesse ou em outro momento, lembrando de sempre lavar as mãos após higienizá-los);

- Higienizar as mãos com água e sabão e/ou preparação alcoólica a $70 \%$;

- Retirar a máscara pelos elásticos;

- Lavar as mãos até a altura dos punhos, com água e sabão, e higienizá-las com álcool em gel 70\%;

- Higienizar o rosto com água e sabão e/ou preparação alcoólica a 70\%;

- Determinar uma área chamada de "contaminada" para deixar roupas e calçados antes de circular pela casa;

- Tomar banho sempre ao chegar, higienizar bem as áreas mais expostas, como mãos, punhos, pescoço e rosto;

- Lavar cabelos, bigode e barba com shampoo e/ou sabonete. 


\section{PROCESSAMENTO DAS ROUPAS E DOS SAPATOS UTILIZADOS EM CLÍNICA}

Procedimentos a serem realizados somente em caso de não haver local apropriado para lavagem dos itens na universidade ou contrato com empresa especializada.

\section{Em clínica}

- Retirar os sapatos do uso em clínica e colocá-los em um saco plástico próprio (limpo e de uso único);

- Em seguida, retirar o pijama cirúrgico (com o mínimo de agitação e manuseio), e colocá-lo em um saco plástico limpo e de uso único;

- Características dos sacos plásticos a serem utilizados: precisam ter qualidade suficiente para resistir ao peso da roupa; tamanho suficiente para serem fechados de forma adequada e que não permitam a abertura durante o transporte.

\section{Transporte}

- Importante colocar em uma bolsa própria para transporte apenas as roupas e os sapatos sujos (não colocar nada além disso nessa bolsa). Lembre-se de que essa bolsa também deverá ser lavada todas as vezes que transportar as roupas e os sapatos sujos. 


\section{Ao chegar em casa}

- Levar as roupas e os sapatos que estão em sacos plásticos diretamente para a lavanderia (ou para a área determinada como "contaminada" em sua casa);

- Limpeza e desinfecção dos sapatos: utilizar água, sabão ou detergente para lavagem. Desinfecção: hipoclorito de sódio (água sanitária) em sua forma mais concentrada ou diluída. Secagem: usar um pano ou secar à sombra. Importante: seguir as informações sugeridas pelo fabricante;

- Lavar o pijama cirúrgico sempre separadamente das demais roupas. Deixar de molho por 30 minutos em hipoclorito de sódio a $0,02 \%$ - $10 \mathrm{~mL}$ de alvejante comercial a 2 ou 2,5\% para cada litro de água (a mistura deve ser feita antes da colocação da roupa para evitar manchas). Lavar em água quente ( $\geq 71$ $\left.{ }^{\circ} \mathrm{C}\right)$ e sabão em quantidade indicada pelo fabricante, secar ao sol ou em secadora e passar com ferro quente;

- Depois de secos, a roupa de uso em clínica e os sapatos devem ser embalados em saco plástico limpo e fechado.

IMPORTANTE: Realizar a lavagem de sua máquina de lavar (ciclo de autolimpeza - hipoclorito de sódio a $1 \%$ ou solução própria) após ser utilizada para lavar o pijama cirúrgico.

\section{Limpeza das máscaras caseiras}

- Devem ser lavadas separadamente de outras roupas;

- Lavar com água corrente e sabão neutro;

- Deixar de molho em solução com água sanitária a 2,5\% (diluir 2 colheres de sopa de água sanitária em 1 litro de água) por 30 minutos;

- Enxaguar bem em água corrente;

- Evitar torcer com força; 
- Deixar secar;

- Passar com ferro quente;

- Verificar se existem danos nas máscaras. Se houver, substituir;

- Guardar em um recipiente fechado.

- Se possuir máquina de lavar, programar o ciclo completo de lavagem (lavagem, enxágue, secagem) de pelo menos 30 minutos com temperatura de lavagem de $60^{\circ} \mathrm{C}$.

\section{Descarte das máscaras caseiras}

- Condições para descarte: perda de elasticidade das hastes de fixação ou deformidade no tecido que possa levar a prejuízos à barreira;

- Máscaras de TNT (tecido não-tecido) são descartáveis;

- Remoção: manusear pelo elástico ao redor das orelhas, não tocar na parte frontal da máscara e jogar fora imediatamente em um saco de papel ou plástico fechado em lixeira com tampa;

- Higienizar imediatamente as mãos após o descarte.
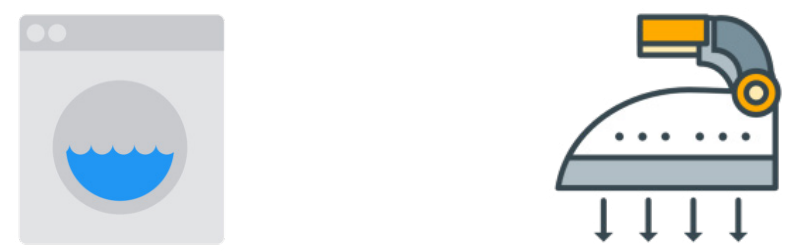


\section{ANEXOS}

\subsection{PARTICULARIDADES - RADIOLOGIA}

IMPORTANTE: Durante a pandemia de COVID-19, os exames de imagem extrabucais como radiografia panorâmica e tomografia computadorizada de feixe cônico são os de primeira escolha, considerando que radiografias intrabucais estimulam a produção de saliva e também a tosse. Portanto, radiografias intrabucais devem ser realizadas apenas quando radiografias extrabucais não puderem detectar o que for necessário. Se forem necessárias tomadas intrabucais, seguir os cuidados descritos a seguir.

\section{Cuidados na recepção do paciente}

- Higienização alcoólica das mãos;

- Higienização do rosto com água e sabão por 20 segundos;

- Colocar $15 \mathrm{~mL}$ da solução de gluconato de clorexidina a 0,12\% sem álcool em um copo plástico grande e pedir ao paciente que bocheche por um minuto (cronometrado) e cuspa novamente no mesmo copo em que o agente químico estava e, então, descarte-o imediatamente na pia. O bochecho deve ser realizado imediatamente antes da tomada radiográfica;

- Colocar a máscara novamente e permanecer com ela até o momento da realização da radiografia.

\section{Cuidados gerais}

- Uso de vestimenta plumbífera (avental, colar de tireoide) para proteção durante o exame radiográfico;

- Não é permitida a permanência de acompanhantes na sala durante o exame radiológico, exceto quando estritamente 
necessária (necessidade de contenção do paciente), e o acompanhante também deverá utilizar vestimenta plumbífera;

- Verificar se pacientes do gênero feminino estão em estado ou suspeita de gravidez;

- Colocar propés e gorro no paciente e sempre higienizar as mãos após colocar os propés;

- Os profissionais (acadêmicos e docentes) devem permanecer do lado de fora da sala durante o disparo dos raios X, para proteção dos profissionais, e estes deverão observar o paciente pela janela de vidro (observar se existe movimentação do paciente durante a incidência radiográfica);

- Realizar as tomadas radiográficas a quatro mãos para diminuir o risco de infecção cruzada (operador e aluno auxiliar).

OBSERVAÇÃO: O aparelho de raios X deve ficar em um ambiente protegido dos aerossóis produzidos no ambulatório da clínica-escola.

\section{PROTOCOLO DE CONTROLE DE INFECÇÃO}

1. Paramentação: seguindo o item 7 deste protocolo geral (p. 29);

2. Preparo da sala:

- Desinfecção dos itens: conforme Quadro 2 (p. 36) deste protocolo geral:

* Bancada de trabalho;

* Cadeira;

* Aparelho de raios X, disparador;

* Maçaneta da porta;

* Vestimenta plumbífera (avental e colar de tireoide).

- Proteger com barreiras físicas:

* Cabeçote do aparelho de raios X;

* Encosto da cadeira; 
* Painel de comando e disparador do equipamento;

* Bancada: campo de TNT descartável e impermeável;

* As barreiras de proteção devem ser retiradas e trocadas após cada atendimento.

\section{Preparo dos materiais:}

- Encapar os filmes radiográficos com filme plástico (PVC) ou com sacos plásticos largos envolvendo o filme e o posicionador;

- Esterilização dos posicionadores $\rightarrow$ IMPORTANTE: somente utilizar posicionadores radiográficos autoclaváveis;

- Colocar na bancada: copo plástico e guardanapo.

\section{Preparo do paciente:}

- Remover aparelho ortodôntico e próteses removíveis;

- Colocar avental de chumbo e protetor de tireoide;

- Disponibilizar guardanapo para o paciente;

- Ajustar o apoio para a cabeça.

\section{Exame radiográfico:}

\section{OPERADOR:}

* Posicionar o paciente;

* Posicionar o conjunto filme/posicionador;

* Posicionar o cilindro localizador;

* Após a tomada radiográfica: retirar o invólucro plástico e dispensar o filme (sem tocá-lo) em um copo plástico.

\section{ALUNO AUXILIAR:}

* Calçar as luvas;

* Posicionar o colete e o protetor de tireoide;

* Acionar o disparo;

* Realizar a desinfecção do filme radiográfico após a exposição (o OPERADOR retira o invólucro e o coloca em um copo plástico, e o aluno AUXILIAR faz a desinfecção);

* Levar o filme para o processamento manual. 


\section{Após o exame radiográfico:}

\section{OPERADOR:}

* Retirar as luvas contaminadas;

* Higienizar as mãos corretamente;

* Remover os protetores de chumbo;

* Dispensar o paciente;

* Transportar os filmes para o processamento radiográfico (nos copos plásticos).

\section{Processamento radiográfico:}

ALUNO AUXILIAR:

* Retirar as luvas contaminadas;

* Higienizar as mãos corretamente;

* Calçar novas luvas;

Entrada na câmara escura para o processamento radiográfico:

- Acender a luz de segurança e fechar a porta.

Durante o processamento radiográfico:

- Abrir os filmes, prendê-los nas colgaduras e processá-los pelo método temperatura/tempo;

- Separar para reciclagem: envelope plástico, papel preto e lâmina de chumbo.

Após o processamento radiográfico:

- Fechar as tampas dos recipientes do revelador e fixador;

- Lavar, secar e deixar aberto o recipiente de água.

Acondicionamento das radiografias:

- Deve ser feito em cartelas plásticas (de fácil desinfecção, caso necessário). 


\subsection{PARTICULARIDADES - PRÓTESE}

Além de todos os cuidados mencionados durante o protocolo geral, atentar para as especificidades relacionadas a seguir para os trabalhos protéticos.

\section{Preparo do box}

Colocar sobre a mesa auxiliar ou próximo ao equipo, dentro do box de atendimento:

- Duas cubas metálicas com água da torneira (uma para utilização durante os ajustes clínicos e outra para o momento da desinfecção do trabalho/prótese);

- Detergente enzimático;

- Papel-toalha;

- Álcool 70\%;

- Sacos plásticos com fecho hermético;

- Pote plástico com tampa hermético.

OBSERVAÇÃO: usuários de próteses ou aparelhos removíveis devem retirá-los antes do bochecho com clorexidina; as(os) próteses/ aparelhos deverão ser limpos com gaze úmida e imersos durante 10 minutos em cuba contendo a solução desinfetante mais apropriada (próteses somente acrílicas: hipoclorito de sódio a 1\%; próteses com metal: clorexidina a $0,2 \%)$.

\section{Ajustes clínicos extraorais de trabalhos protéticos}

1. Após remover qualquer peça/trabalho da boca do paciente para ajustes, enxaguá-lo inicialmente de 4 a 5 vezes ou durante 20 segundos com movimentos pendulares dentro de uma cuba metálica (tamanho compatível com o item) contendo água de torneira - não enxaguá-lo em água corrente, de modo a evitar a formação de aerossol no ambiente; 
2. Se a peça/trabalho estiver contaminada com sangue, proceder como no tópico anterior. Entretanto, a cuba deverá conter água de torneira e detergente enzimático;

3. Secar o item com papel-toalha - não utilizar a seringa de ar para a secagem para evitar a formação de aerossol no ambiente;

4. Desinfetar o item por meio de fricção com álcool 70 (p. 36);

5. Realizar os ajustes necessários;

6. Provar a peça/trabalho novamente na boca do paciente;

7. Todas as vezes que remover o item da boca do paciente, proceder como descrito nos tópicos anteriores, substituindo a água da cuba por água limpa e realizando a desinfecção prévia da cuba.

\section{Desinfecção dos trabalhos protéticos (realizados pelo aluno auxiliar) após ajustes clínicos}

1. Após os ajustes finais e a remoção do item da boca do paciente, utilizar a cuba contendo água de torneira e enxaguar de 4 a 5 vezes ou durante 20 segundos com movimentos pendulares. Não utilizar torneira (não lavar em água corrente). Se houver contaminação com sangue, enxaguar da mesma forma na cuba contendo água e detergente enzimático;

2. Secar o item com papel-toalha - não utilizar seringa; não produzir aerossol;

3. Seguir os procedimentos de desinfecção de acordo com o Quadro 4, a seguir.

3.1. Se o item for passível de imersão: submergi-lo em uma cuba limpa contendo a solução desinfetante, tampar a cuba e aguardar o período da desinfecção;

3.2. Se o item não for passível de imersão em razão da possibilidade de distorção/instabilidade dimensional: umedecer o item com a solução desinfetante, retirar o excesso da solução com papel-toalha, envolver o item em gazes umedecidas utilizando frasco almotolia bico reto (não utilizar spray; não aspergir a solução para evitar formação 
de aerossol) com a solução desinfetante, envolver o item nas gazes, colocá-lo dentro de plásticos com fecho hermético e aguardar o período de desinfecção;

\section{Quadro 4. Procedimentos indicados para a desinfecção de moldes, modelos e próteses}

\begin{tabular}{|c|c|c|c|}
\hline Material & Desinfetante & Técnica & Tempo \\
\hline $\begin{array}{l}\text { Alginato ou } \\
\text { Hidrocoloide } \\
\text { irreversível }\end{array}$ & $\begin{array}{c}\text { Hipoclorito de } \\
\text { sódio a } 1 \% \text { ou } \\
\text { solução de Milton }\end{array}$ & $\begin{array}{l}\text { Envolto em gazes } \\
\qquad(3.2)\end{array}$ & 10 minutos \\
\hline $\begin{array}{l}\text { Hidrocoloide } \\
\text { reversível }\end{array}$ & $\begin{array}{c}\text { Hipoclorito de } \\
\text { sódio a } 1 \% \text { ou } \\
\text { solução de Milton }\end{array}$ & $\begin{array}{l}\text { Envolto em gazes } \\
\qquad(3.2)\end{array}$ & 10 minutos \\
\hline $\begin{array}{l}\text { Silicone por } \\
\text { condensação }\end{array}$ & $\begin{array}{l}\text { Hipoclorito de } \\
\text { sódio a } 1 \% \text { ou } \\
\text { solução de Milton }\end{array}$ & Imersão (3.1) & 10 minutos \\
\hline Silicone por adição & $\begin{array}{c}\text { Hipoclorito de } \\
\text { sódio a } 1 \% \text { ou } \\
\text { solução de Milton }\end{array}$ & Imersão (3.1) & 10 minutos \\
\hline $\begin{array}{l}\text { Mercaptana ou } \\
\text { Polissulfeto }\end{array}$ & $\begin{array}{c}\text { Hipoclorito de } \\
\text { sódio a } 1 \% \text { ou } \\
\text { solução de Milton }\end{array}$ & Imersão (3.1) & 10 minutos \\
\hline Poliéter & $\begin{array}{c}\text { Hipoclorito de } \\
\text { sódio a } 1 \% \text { ou } \\
\text { solução de Milton }\end{array}$ & $\begin{array}{l}\text { Envolto em gazes } \\
\qquad(3.2)\end{array}$ & 10 minutos \\
\hline Godiva & $\begin{array}{c}\text { Ácido peracético a } \\
1 \%\end{array}$ & Imersão (3.1) & 10 minutos \\
\hline Pasta zincoenólica & $\begin{array}{c}\text { Ácido peracético a } \\
1 \%\end{array}$ & Imersão (3.1) & 10 minutos \\
\hline $\begin{array}{l}\text { Modelos de gesso } \\
\text { manuseados ou } \\
\text { contaminados com } \\
\text { saliva }\end{array}$ & $\begin{array}{l}\text { Suspensão de água } \\
\text { de gesso com } \\
\text { hipoclorito de sódio } \\
\text { a 0,5\% (líquido de } \\
\text { Dakin) }\end{array}$ & Imersão & $\begin{array}{l}30 \text { minutos e deixar } \\
\text { secar naturalmente }\end{array}$ \\
\hline $\begin{array}{l}\text { Próteses ou peças } \\
\text { de prova acrílicas }\end{array}$ & $\begin{array}{c}\text { Hipoclorito de } \\
\text { sódio a } 1 \% \text { ou } \\
\text { solução de Milton }\end{array}$ & Imersão (3.1) & 10 minutos \\
\hline $\begin{array}{c}\text { Próteses ou peças } \\
\text { de prova com } \\
\text { metal }\end{array}$ & $\begin{array}{c}\text { Solução de } \\
\text { clorexidina a 0,2\% } \\
\text { ou Ácido peracético } \\
\text { a } 1 \%\end{array}$ & Imersão (3.1) & 10 minutos \\
\hline
\end{tabular}


4. Passado o período de desinfecção, enxaguar o item de 4 a 5 vezes ou durante 20 segundos novamente com movimentos pendulares em cuba previamente limpa contendo água de torneira;

5. Secar o item com papel-toalha e embalar;

6. Após desinfecção:

6.1. Se houver a necessidade de trabalhar imediatamente no item nos laboratórios anexos aos dispensários clínicos (como, por exemplo, para vazamento de moldes, montagem em articulador semiajustável ou outro), retirar-se do ambiente clínico e transportar o item para a sala anexa. Após a realização do procedimento laboratorial, retornar ao box de atendimento para limpeza e desinfecção final (p. 53 a 57);

6.2. Se o item for trabalhado no laboratório de prótese da UEPG ou por laboratório terceirizado, após desinfecção, colocar o item dentro de saco hermético (em ambiente de $100 \%$ de umidade relativa, no caso do hidrocoloide irreversível), e o saco, por sua vez, dentro de uma caixa hermética para ser enviada ao laboratório e, então, retirar-se do ambiente clínico (p. 44; 53 a 57).

OBSERVAÇÃo: Realizar a desinfecção na pia de apoio localizada em anexo aos equipos (não usar a pia destinada à lavagem de mãos), porém não lavar nada em água corrente para evitar a formação de aerossol.

\section{Procedimentos realizados no laboratório de prótese anexo ao dispensário clínico}

- Antes de entrar no ambiente anexo ao dispensário clínico, o aluno AUXILIAR deve calçar novas luvas de procedimento, realizar a limpeza e a desinfecção do face shield, descartar essas luvas em lixo biológico, realizar a higienização alcoólica das mãos, colocar novamente o face shield, vestir um avental 
descartável novo (gramatura mínima de $50 \mathrm{~g} / \mathrm{m}^{2}$ ) e novas luvas limpas de procedimento;

- Entrar no laboratório portando apenas o material necessário para a realização do procedimento;

- Todo o instrumental que adentrar esse ambiente deverá estar estéril ou, quando o material não for passível de esterilização, deverá ter sido previamente desinfetado (p.36);

- Materiais de uso comum laboratorial (gesso, resina acrílica, cera etc.) poderão ser fracionados em pequenas porções acondicionadas em pacotes plásticos, com a finalidade de evitar desperdícios e contaminação cruzada;

- Proteger a bancada de trabalho com campo descartável impermeável;

- Se o trabalho a ser executado no laboratório for gerador de aerossol, realizar o procedimento dentro de câmaras de desgaste (Figura 11). O aluno deve colocar o item, a peça de mão e algum instrumental que se faça necessário dentro da câmara e, então, realizar o procedimento. Após a realização do trabalho, o aluno deve proceder à desinfecção da câmara de desgaste (p.36).

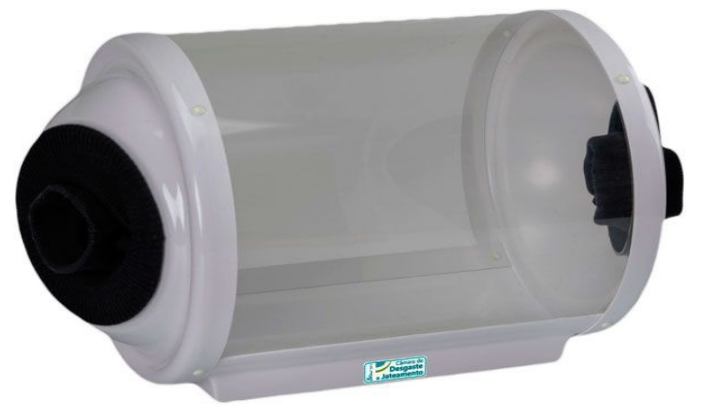




\section{Procedimentos realizados no laboratório interno de prótese da UEPG}

- o técnico em prótese (paramentado - p. 29), ao receber os itens enviados pelos acadêmicos, deverá repetir os mesmos procedimentos de desinfecção como se eles não tivessem sido realizados e seguir as mesmas recomendações mencionadas anteriormente;

- Retornar o item para os acadêmicos após a realização de desinfecção e acondicionamento (saco plástico e caixa hermética) adequados, como descrito anteriormente.

\section{Ao receber os trabalhos protéticos nas clínicas da UEPG}

- Seguir todos os cuidados descritos anteriormente para o enxágue e a desinfecção dos itens.

OBSERVAÇÃO: se for necessário enviar articulador semiajustável, delineador ou outro dispositivo, fazer a desinfecção do aparato (p.36), acondicioná-lo em saco plástico e fechá-lo adequadamente. Ao receber o dispositivo, realizar novamente sua desinfecção.

\section{Procedimentos de biossegurança para fluxo digital}

Cada etapa do tratamento protético em que um trabalho é fisicamente transportado de uma clínica para um laboratório, e vice-versa, pode resultar em contaminação cruzada. Nesse sentido, um aspecto importante é que o fluxo totalmente digital em prótese proporciona vários benefícios relacionados à prevenção de infecção, sem exigir a desinfecção dos moldes. O fluxo digital também reduz as etapas e o número de consultas e, portanto, o possível risco de infecção (Figura 12). Desse modo, sua implementação se justifica principalmente durante a pandemia de COVID-19. 


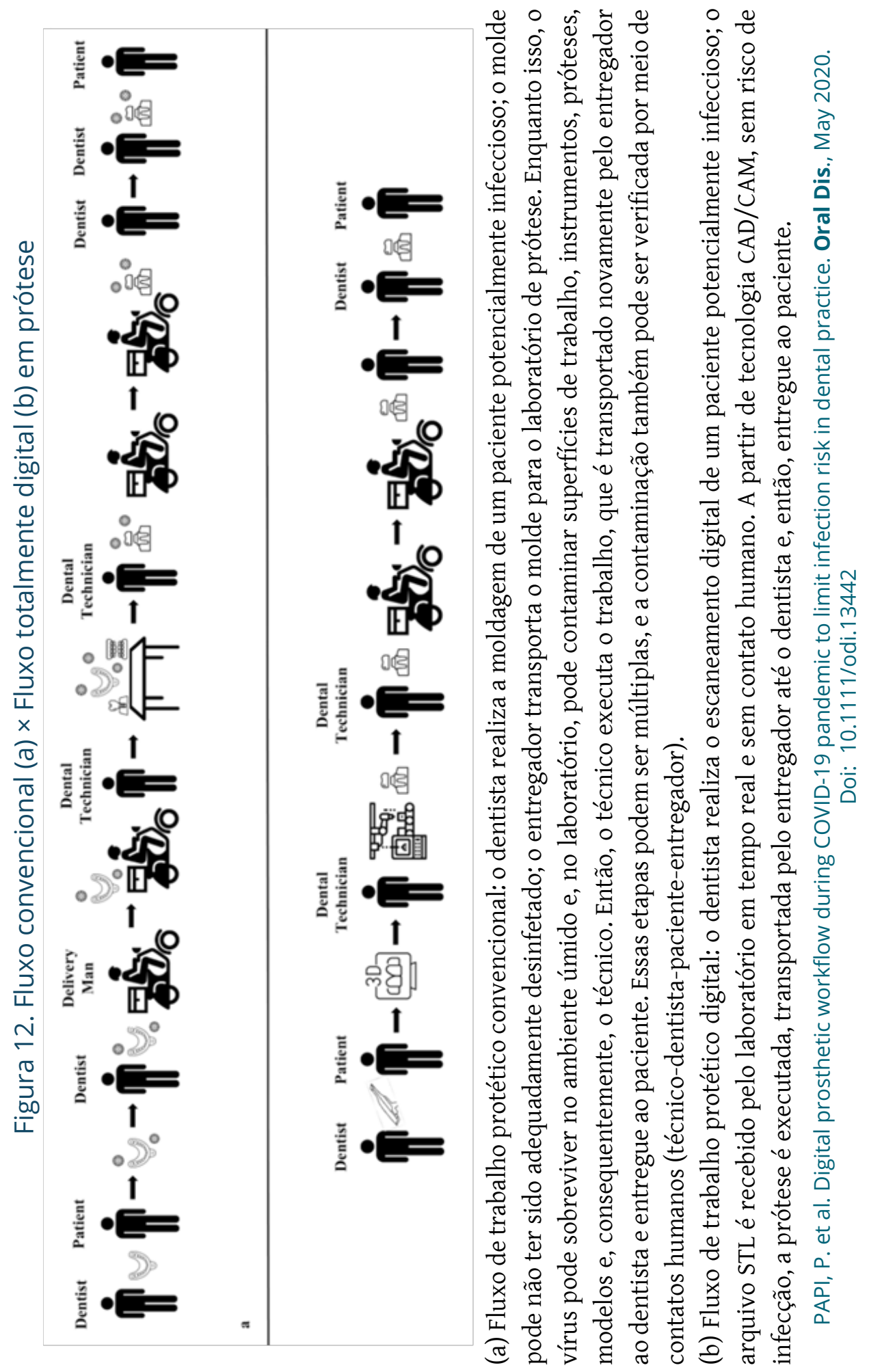




\section{Cuidados durante a execução de trabalhos utilizando tecnologia digital}

- Proteção com barreiras físicas (filmes PVC) nos equipamentos de uso comum dentro do laboratório digital, seguindo os mesmos procedimentos de um laboratório convencional;

- Manipulação dos equipamentos utilizando paramentação adequada (técnicos - p. 29);

- Desinfecção de equipamentos utilizando fricção com álcool a 70\%, se possível, e de acordo com as instruções do fabricante;

- Desinfecção de eletrônicos utilizando fricção com álcool isopropílico a $70 \%$;

- Ponteiras de escaneamento devem ser higienizadas com escova de dentes de cerdas macias com água e sabão, enxágue, secagem eficiente e cuidadosa com pano descartável sem fiapos e esterilização em autoclave, conferindo as recomendações do fabricante;

- As peças de mão devem ser desinfetadas com toalha com álcool isopropílico a $70 \%$. 


\subsection{PARTICULARIDADES - ODONTOPEDIATRIA}

A literatura mostra que a maioria das crianças, se infectadas pelo novo coronavírus, tem um curso benigno da doença, com sintomas respiratórios brandos e baixa taxa de mortalidade. Acredita-se também que os índices reportados de crianças contaminadas pelo novo coronavírus são menores do que o esperado. Considerando-se ainda os pacientes assintomáticos e aqueles pré-sintomáticos em período de incubação (entre 1 e 14 dias), as normas descritas neste manual devem ser aplicadas igualmente a todos os pacientes infantis atendidos.

\section{Cuidados pré-operatórios}

O agendamento de consultas e a verificação do estado real de saúde da criança e de seus familiares devem seguir as orientações constantes nas p. 21 e 22 deste manual.

Todavia, como a Odontopediatria é uma especialidade que demanda o estabelecimento de um vínculo com o paciente e seu núcleo familiar, é necessário que a criança se familiarize com seu dentista e que o acadêmico desenvolva empatia com os sentimentos dos pacientes, além de entender seus medos e suas ansiedades para melhor conduzir as medidas de controle de comportamento na clínica odontopediátrica. Portanto, o fato de não haver a conversa inicial com o paciente e de a criança se encontrar pela primeira vez com seu dentista já paramentado pode influenciar negativamente o comportamento durante a consulta.

Dessa forma, procedimentos adicionais para o paciente infantil devem ser realizados antes da consulta presencial. A abordagem possível de ser executada por profissionais e acadêmicos nesse momento é a realização de uma pré-consulta via videoconferência por meio de aplicativos como WhatsApp, Skype ou similares. 


\section{POR QUE FAZER A VIDEOCHAMADA?}

\section{Para os pais:}

- Para que eles recebam com clareza as informações sobre os cuidados desde a saída de casa até a chegada à UEPG, conforme descrito neste manual na p. 16 a 18 e 69;

- Para que eles entendam a necessidade de pontualidade;

- Para que eles saibam que a criança deve ser acompanhada por apenas um responsável;

- Para que eles compreendam que não se deve levar nada além do estritamente necessário para a consulta (como, por exemplo, mochilas, brinquedos, bolsas e sacolas).

\section{Para a criança:}

- Para que a criança se familiarize com o dentista que vai atendê-la sem a paramentação;

- Para que ela seja informada sobre as mudanças no ambiente, como eliminação dos brinquedos e lápis de cor na sala de espera;

- Para que ela crie um vínculo inicial com o acadêmico que vai atendê-la;

- Para que ela entenda que beijos e abraços não são mais permitidos e por que razão;

- Para que ela entenda que o uso da máscara é obrigatório até o momento em que ela for chamada para iniciar o atendimento.

\section{Para o acadêmico:}

- Para apresentar-se ao paciente e iniciar a formação de um vínculo;

- Para conhecer os interesses e os desinteresses de seu paciente;

- Para identificar as características da criança que podem influenciar o tratamento, como medo, ansiedade, facilidade ou dificuldade de comunicação; 
- Para obter o consentimento inicial dos pais para início do tratamento (anamnese);

- Para realizar a anamnese com os responsáveis segundo a ficha clínica da UEPG.

\section{Vídeo do dentista realizando a paramentação}

Paralelamente à videochamada, um vídeo produzido pelos alunos da UEPG mostrando o passo a passo da paramentação necessária ao atendimento deverá ser encaminhado para o celular do pai, da mãe ou dos responsáveis, que se encarregarão de exibi-lo ao paciente antes da consulta.

Esse vídeo busca dessensibilizar a criança com relação aos novos EPIs necessários e familiarizá-la com a paramentação, facilitando a aceitação do atendimento.

\section{Cuidados operatórios}

- Antes de entrar na sala de consulta, o paciente deve ser orientado a lavar as mãos com sabonete líquido e se paramentar com touca e avental descartáveis e óculos de proteção sempre que possível. A capacidade de cooperação individual da criança deve ser levada em conta;

- No equipo, colocar os propés no paciente e realizar a higienização de seu rosto com clorexidina a 0,2\%;

- Os pacientes devem realizar bochecho com $15 \mathrm{~mL}$ de solução de gluconato de clorexidina a 0,12\% durante 1 min. Colocar a solução em um copo plástico grande, pedir ao paciente que bocheche e cuspa no mesmo copo. 0 acadêmico aspira, então, o conteúdo do copo plástico. Se a criança ainda não conseguir bochechar, a clorexidina pode ser aplicada por meio de 
embrocação (limpeza da cavidade bucal da criança com gaze embebida em 2 mL da solução de clorexidina);

- Definir um plano de tratamento, priorizando o uso de métodos minimamente invasivos e redutores de aerossol;

- A logística do tratamento deve ser voltada para medidas resolutivas, com a realização do maior número de procedimentos em uma mesma sessão, considerando a idade e o nível de cooperação oferecido pela criança;

- Evitar o uso de spray ar/água com seringa tríplice; substituí-lo por seringas descartáveis com soro fisiológico para lavagem e bolinhas de algodão/gaze para secagem;

- Crianças imunologicamente deprimidas devem ser atendidas na primeira consulta do dia;

- Crianças com doença cárie ativa e múltiplas cavidades: adotar procedimentos efetivos, simples e capazes de inativar as lesões, como tratamento restaurador atraumático, aplicações tópicas de vernizes fluoretados e diamino fluoreto de prata;

- Em situações em que for necessário o uso de alta rotação, como para abertura endodôntica: realizar o procedimento após isolamento absoluto, devendo ser agendado como a última consulta do dia;

- Sempre que possível, priorizar o uso de técnicas radiográficas extraorais para diagnóstico;

- Orientar e instituir medidas de cuidado que podem ser realizadas pelo paciente/pais em casa, como escovação dentária com dentifrício fluoretado, bochechos com soluções fluoretadas (de acordo com o risco individual) e controle de ingestão de sacarose;

- SALA DE ESCOVAÇÃO/ESCOVÓDROMO: a utilização das salas de escovação/escovódromo deve ser evitada em virtude do risco de contaminação. Os procedimentos de orientação devem ser realizados no box de atendimento. 


\section{O acompanhante pode entrar na sala de consulta com a criança?}

Preferencialmente, o responsável deve permanecer na sala de espera, com máscara. Situações especiais em que a presença do acompanhante será requisitada na sala de consulta envolvem:

- Crianças menores de 3 anos;

- Crianças com comportamento não cooperativo que necessitam atendimento odontológico imediato com estabilização protetora (deverá ser realizada pelo acompanhante);

- Crianças portadoras de necessidades especiais sem capacidade de obedecer aos comandos do profissional.

Nesses casos, o acompanhante deverá estar paramentado com máscara, touca, propé e avental descartáveis e óculos de proteção.

\section{Cuidados adicionais}

Se uma bolsa de mão, por exemplo, foi levada pela mãe, esta deve ser acondicionada em um saco, ou sacola, plástico fornecido pela UEPG. Também é comum que a criança peça para entrar na sala de consulta com um brinquedo preferido. Nesse caso, o brinquedo também deve ser acondicionado em um saco plástico. Em ambos os casos, o acondicionamento dos objetos deve ser realizado antes da entrada na sala clínica.

\section{Após o atendimento}

A criança e seu acompanhante (se entrou na sala de consulta) serão orientados para a remoção dos EPIs utilizados, que devem ser descartados conforme orientação deste manual. Ambos devem ser orientados a higienizar novamente as mãos e colocar imediatamente uma máscara caseira limpa trazida de casa. 


\subsection{DISCIPLINAS LABORATORIAIS}

\section{Medidas de proteção aluno/professor}

Para a realização de qualquer procedimento laboratorial, os alunos e professores deverão:

- Levar somente objetos estritamente necessários para o laboratório;

- Retirar a máscara caseira;

- Higienizar as mãos com água e sabão;

- Higienizar o rosto com gaze e clorexidina a 0,2\%;

- Paramentar-se de acordo com o item 7 deste protocolo geral (p. 29). Em caso de procedimentos não geradores de aerossol, pode-se utilizar máscara cirúrgica com tripla proteção (tipo IIR) e avental descartável impermeável gramatura $30 \mathrm{~g} / \mathrm{m}^{2}$ ).

- Cobrir cortes e abrasões de pele, principalmente das mãos, antes de manusear qualquer área do laboratório;

- Realizar a higienização das mãos: antes e após os procedimentos laboratoriais; antes de calçar as luvas e imediatamente após a retirada destas; realizar sempre que as mãos forem contaminadas durante um procedimento ou se houver alguma perfuração das luvas;

- Uso de luvas: é obrigatório nos laboratórios. Elas devem ser desprezadas quando estiverem contaminadas, quando o trabalho com materiais infecciosos for concluído ou quando a integridade da luva estiver comprometida. Luvas descartáveis não poderão ser lavadas, reutilizadas ou usadas para tocar superfícies "limpas" (teclado, telefones etc.) e não devem ser utilizadas fora do laboratório. 


\section{Medidas de proteção relacionadas ao ambiente}

- Respeitar o distanciamento social (2 metros entre as cadeiras), intercalando bancadas de trabalho;

- Presença de lixeiras com acionamento por pedal;

- Presença de dispensador de álcool em gel 70\%;

- Manter as janelas abertas. Se o ar-condicionado for utilizado, ele precisa ter exaustão que garanta trocas de ar;

- É proibido comer e beber nas dependências dos laboratórios;

- Não passar cosméticos nas instalações do laboratório;

- Não manusear lentes de contato nos laboratórios, e estas devem sempre estar protegidas por óculos adequados;

- É proibida a utilização de celulares nos laboratórios quando houver manipulação de material biológico e agentes tóxicos;

- Manter todos os frascos contendo material infectante fechados quando não estiverem em uso. Não colocar materiais contaminados na superfície do balcão de trabalho; não andar com pipetas pelo laboratório; não descartar fluidos contaminados na pia; não causar derramamento de material na bancada de trabalho;

- Não levar luvas para fora da área de trabalho;

- Lavar as mãos antes de sair do laboratório;

- Realizar a desinfecção de equipamentos e instrumentos de uso compartilhado em laboratório, como microscópio, por exemplo. 


\section{Medidas de proteção durante as aulas laboratoriais}

- O professor deve realizar demonstrações por meio de sistemas de vídeo e projeção, para evitar qualquer tipo de aglomeração;

- O professor deve, preferencialmente, ir até a bancada de cada estudante, visando diminuir o trânsito no ambiente do laboratório;

- Caso o professor precise ficar em sua bancada, os estudantes devem ir até ele, sempre respeitando o distanciamento mínimo de 2 metros entre eles;

- Quando forem utilizados dentes naturais, estes devem ser previamente autoclavados;

- A distribuição dos materiais de uso em laboratório deve ser realizada pelo técnico, que será responsável pela desinfecção sempre que for necessário;

- Importante: baixa e alta rotação devem ser autoclavados antes e após a utilização;

- PROIBIDO: compartilhar ou emprestar materiais. 


\section{Medidas de proteção durante procedimentos laboratoriais}

- Culturas, tecidos e amostras de fluidos corpóreos ou dejetos potencialmente infecciosos devem ser armazenados em recipiente com tampa, evitando assim o vazamento durante a coleta, o manuseio, o processamento e o transporte destes;

- A pipetagem utilizando os lábios é proibida;

- Todo procedimento técnico deve ser executado minimizando a formação de aerossóis. Sempre que houver probabilidade de formação de aerossol, sugere-se que o trabalho seja realizado em cabines de segurança ou câmaras de desgaste;

- Procedimentos utilizando materiais biológicos devem ser realizados utilizando bico de Bunsen, e os alunos devem ser orientados a realizar as etapas experimentais posicionando-se sempre próximos à chama. 


\section{CONSIDERAÇÕES FINAIS}

No cenário atual, as incertezas e a falta de conhecimento estão dominando o processo de tomada de decisão clínica. A extrema dinamicidade da pandemia e a coleta de novas informações podem determinar alterações repentinas de condutas e recomendações para a prevenção da infecção por SAR-CoV-2 (IZZETTI et al., 2020). De forma geral, os profissionais de Odontologia parecem extremamente expostos ao risco de infecção, tornando necessária a adoção de medidas preventivas rigorosas. Esperamos que, em breve, retornemos à Odontologia anterior ao "novo normal", mas é preciso lembrar que nossa profissão pode mudar significativamente nos próximos anos (IZZETTI et al., 2020). Questões como "O que deve ser feito para melhorar as estratégias atuais de prevenção e controle de infecções pós-pandemia?" e "Como responder a possíveis doenças altamente contagiosas como essa no futuro?" ainda permanecem sem respostas e demandam um debate contínuo (MENG et al., 2020). 


\section{REFERÊNCIAS}

AMERICAN DENTAL ASSOCIATION. ADA releases interim guidance on minimizing COVID-19 transmission risk when treating dental emergencies. ADA, abr 2020. Disponível em: https://www.ada.org/ en/publications/ada-news/2020-archive/april/ada-releases-interimguidance-on-minimizing-covid-19-transmission-risk-when-treatingemergencies. Acesso em: 10 abr. 2020.

AMERICAN DENTAL ASSOCIATION. Return to work interim guidance toolkit. ADA, may 2020. Disponível em: https://success.ada.org/ /media/ CPS/Files/Open\%20Files/ADA_Return_to_Work_Toolkit.pdf. Acesso em: 28 jul. 2020.

ANUSAVICE, K. Phillips materiais dentários. 11. ed. Rio de Janeiro: Elsevier, 2005.

ASSOCIAÇÃO BRASILEIRA DE NORMAS TÉCNICAS. NBR 7256: tratamento de ar em estabelecimentos assistenciais de saúde (EAS): requisitos para projeto e execução das instalações. Rio de Janeiro: ABNT; 2005. Disponível em: https://www.abntcatalogo.com.br/norma.aspx?ID=994. Acesso em: 13 ago. 2020.

BAGHIZADEH FINI, M. What dentists need to know about COVID-19. Oral Oncol., v. 105. Jun 2020. Doi: 10.1016/j.oraloncology.2020.104741.

BRASIL DE FATO. Brasil de Fato: uma visão popular do Brasil e do mundo. Saiba quais são os tecidos recomendados pela OMS para as máscaras de pano caseiras: Disponível em: https://www.brasildefato.com. br/2020/06/09/saiba-quais-sao-os-tecidos-recomendados-pela-oms-paraas-mascaras-de-pano-caseira. Acesso em: 03 jul. 2020.

BRASIL. Agência Nacional de Vigilância Sanitária. Como fazer higiene das mãos com preparação alcoólica e com sabonete líquido e água: cartaz. ANVISA. Disponível em: https://www20.anvisa.gov.br/ segurancadopaciente/index.php/publicacoes/item/cartaz-como-fazerhigiene-das-maos-com-preparacao-alcoolica-e-com-sabonete-liquido-eagua. Acesso em: 04 jun. 2020. 
BRASIL. Ministério da Saúde. Agência Nacional de Vigilância Sanitária. Nota técnica CGSB/DESF/SAPS/MS no 9, de 11 mar de 2020. COVID-19 e atendimento odontológico no SUS. Disponível em: http://www.crosp. org.br/uploads/arquivo/ab69d79b87d04780af08a70d8cee9d70.pdf. Acesso em: 02 abr. 2020.

BRASIL. Ministério da Saúde. Agência Nacional de Vigilância Sanitária. Desparamentação de EPIs: cartaz. ANVISA. Disponível em: https:// www20.anvisa.gov.br/segurancadopaciente/index.php/publicacoes/ item/desparamentacao-de-epis. Acesso em: 04 jun. 2020.

BRASIL. Ministério da Saúde. Agência Nacional de Vigilância Sanitária. Orientações gerais: máscaras faciais de uso não profissional. Brasília: Anvisa 2020.11p. Disponível em: http://portal.anvisa.gov.br/ documents/219201/4340788/NT+M\%C3\%A1scaras.pdf/bf430184-855042cb-a975-1d5e1c5a10f7. Acesso em: 15 jun. 2020.

BRASIL. Ministério da Saúde. Agência Nacional de Vigilância Sanitária. Serviços odontológicos: prevenção e controle de riscos. Brasília: Anvisa 2006. 152p. Disponível em: http://portal.anvisa. gov.br/resultado-de-busca?p_p_id=101\&p_p_lifecycle $=0 \& p \_p$ $\underline{\text { state}=\text { maximized\&p_p_mode }=\text { view\&p_p_col_id=column }-1 \& p \_p \_c o l}$ count $=1 \& \_101 \_$struts_action $=\% 2 F a s s e t \_p u b l i s h e r \% 2 F v i e w \_c o n t e n t \& \_101$ assetEntryId=271950\&_101_type=document. Acesso em: 07 abr. 2020.

BRASIL. Ministério da Saúde. Agência Nacional de Vigilância Sanitária. Esclarecimentos sobre a reabertura de clínicas odontológicas: Nota Técnica № 173/2020/SEI/GRECS/GGTES/DIRE1/ANVISA. Brasília - DF. Junho de 2020. 4p. Disponível em: https://www.cristofoli. com/biosseguranca/wp-content/uploads/2020/06/ANVISA_-NotaT\%C3\%A9cnica_173_CROSP.pdf. Acesso em: 20 jun. 2020.

BRASIL. Ministério da Saúde. Agência Nacional de Vigilância Sanitária. Gerência de Vigilância e Monitoramento em Serviços de Saúde. Gerência Geral de Tecnologia em Serviços de Saúde. NOTA TÉCNICA GVIMS/ GGTES/ ANVISA № 04/2020. Orientações para serviços de saúde: medidas de prevenção e controle que devem ser adotadas durante a assistência aos casos suspeitos ou confirmados de infecção pelo novo coronavírus (SARS-CoV-2). Brasília - DF. Março de 2020. 75p. Disponível em: http://portal.anvisa.gov.br/documents/33852/271858/ Nota+T\%C3\%A9cnica+n+04-2020+GVIMS-GGTES-ANVISA/ab598660-3de44f14-8e6f-b9341c196b28. Acesso em: 13 mai. 2020. 
BRASIL. Ministério da Saúde. Agência Nacional de Vigilância Sanitária. Resolução - RDC no 222, de 28 de março de 2018. Brasília: Ministério da Saúde, 2018. Disponível em: http://portal.anvisa.gov.br/ documents/10181/3427425/RDC_222_2018_pdf/c5d3081d-b331-46268448-c9aa426ec410. Acesso em: 13 mai. 2020.

BRASIL. Ministério da Saúde. Agência Nacional de Vigilância Sanitária. Resolução - RDC no 63, de 25 de novembro de 2011. Brasília: Ministério da Saúde, 2011. Disponível em: https://www20.anvisa.gov. br/segurancadopaciente/index.php/legislacao/item/rdc-63-de-25-denovembro-de-2011. Acesso em: 13 mai. 2020.

CAI, J. et al. Indirect virus transmission in cluster of COVID-19 cases, Wenzhou, China, 2020. Emerg Infect Dis., v. 26, n. 6, p. 1343-5, Jun 2020. Doi: 10.3201/eid2606.200412.

CHEN, J. Pathogenicity and transmissibility of 2019-nCoV - A quick overview and comparison with other emerging viruses. Microbes Infect., v. 22, n. 2, p. 69-71, Mar 2020. Doi: 10.1016/j.micinf.2020.01.004.

CONSELHO FEDERAL DE ENFERMAGEM/CONSELHO REGIONAL DE ENFERMAGEM. Covid-19. Orientações sobre a colocação e retirada dos equipamentos de proteção individual (EPIs). 18p. Disponível em: http://www.cofen.gov.br/wp-content/uploads/2020/03/cartilha_epi.pdf. Acesso em: 1 ago. 2020.

CONSELHO FEDERAL DE ODONTOLOGIA. Biossegurança e desinfecção de materiais de moldagem e moldes para profissionais de prótese dentária (cirurgiões dentistas e TPD). Rio de Janeiro - RJ. Abril de 2020. 21p. Disponível em: http://website.cfo.org.br/wp-content/ uploads/2020/04/Manual-Desinfeccao-1.pdf. Acesso em: 23 jun. 2020.

CONSELHO FEDERAL DE ODONTOLOGIA. Manual de boas práticas em biossegurança para ambientes odontológicos. Rio de Janeiro - RJ. Março de 2020. 42p. Disponível em: http://website.cfo.org. br/wp-content/uploads/2020/04/cfo-lanc\%CC\%A7a-Manual-deBoas-Pra\%CC\%81ticas-em-Biosseguranc\%CC\%A7a-para-AmbientesOdontologicos.pdf. Acesso em: 06 abr. 2020.

CONSELHO REGIONAL DE ODONTOLOGIA DO PARANÁ - CRO/PR. Controle de infecção e biossegurança: procedimentos operacionais padrão. 1 ed. Curitiba. 2012. 75p. Disponível em: http://www.cropr.org.br/uploads/ arquivo/42cd1c7049af88dca8f9135d8c04b274.pdf. Acesso em: 11 abr. 2020. 
COVID-19 Dental Services Evidence Review (CoDER) Working Group. Recommendations for the re-opening of dental services: a rapid review of international sources. Disponível em: https://oralhealth. cochrane.org/sites/oralhealth.cochrane.org/files/public/uploads/ covid19_dental_reopening_rapid_review_13052020.pdf. Acesso em: 12 mai. 2020.

DAY, M. Covid-19: four fifths of cases are asymptomatic, China figures indicate. BMJ., v. 369. Apr 2020. Doi: 10.1136/bmj.m1375

ESP CEARÁ. Colocação da mascara N95: video. YoutubeBR. Disponível em: https://www.youtube.com/watch?v=UB3lN1VdH_I. Acesso em: 06 jun. 2020.

FALLAHI, H.R. et al. Being a front-line dentist during the Covid-19 pandemic: a literature review. Maxillofac Plast Reconstr Surg., v. 42, n. 1, p. 12, Apr 2020. Doi: 10.1186/s40902-020-00256-5.

FIOCRUZ. Manual sobre biossegurança para reabertura de escolas no contexto da COVID-19. Rio de Janeiro, versão 1.0, Jul 2020. 41p. Disponível em: https:/portal.fiocruz.br/sites/portal.fiocruz.br/files/ documentos/manual_reabertura.pdf. Acesso em: 20 jul. 2020.

FRANCO, J.B. et al. Cuidados odontológicos na era do COVID-19: recomendações para procedimentos odontológicos e profissionais. Rev Assoc Paul Cir Dent., v. 74, n. 1, p. 18-21, mar 2020.

GE, Z.Y. et al. Possible aerosol transmission of COVID-19 and special precautions in dentistry. J Zhejiang Univ Sci B., v. 21, n. 5, p. 361-8, May 2020. Doi: $\underline{10.1631 / \text { jzus.B2010010. }}$

GUO, Y.R. et al. The origin, transmission and clinical therapies on coronavirus disease 2019 (COVID-19) outbreak - an update on the status. Mil Med Res., v. 7, n. 1, p. 11, Mar 2020. Doi: 10.1186/s40779-020-00240-0.

ILLINOIS DEPARTMENT OF PUBLIC HEALTH. Revised interim guidance: provision of routine oral and dental care. Version number 2.0, May 2020. Disponível em: https://www.dph.illinois.gov/covid19/communityguidance/routine-oral-and-dental-care. Acesso em: 11 jun. 2020.

IZZETTI, R. et al. COVID-19 transmission in dental practice: brief review of preventive measures in Italy. J Dental Res., v. 99, n. 9, p. 1030-8, Aug 2020. Doi: $10.1177 / 0022034520920580$ 
JF DEPRESSÃO. Como guardar a sua máscara N95: vídeo. YoutubeBR. Disponível em: https://www.youtube.com/watch?v=3lnChqvmw24. Acesso em: 06. jun. 2020.

KAMPF, G. et al. Persistence of coronaviruses on inanimate surfaces and their inactivation with biocidal agents. J Hosp Infect., v. 104, n. 3, p. 24651, Mar 2020. Doi: 10.1016/j.jhin.2020.01.022.

LI, Y. et al. Saliva is a non-negligible factor in the spread of COVID-19. Mol Oral Microbiol., v. 35, n. 4, p. 141-5, Aug 2020. Doi: 10.1111/omi.12289.

LIN, K.; MARR, L.C. Humidity-dependent decay of viruses, but not bacteria, in aerosols and droplets follows disinfection kinetics. Environ Sci Technol., v. 54, n. 2, p. 1024-32, Jan 2020. Doi:10.1021/acs.est.9b04959.

LIU, Y. et al. Aerodynamic analysis of SARS-CoV-2 in two Wuhan hospitals. Nature, v. 582, n. 7813, p. 557-60, Jun 2020. Doi: 10.1038/s41586-020-2271-3.

LO GIUDICE, R. The severe acute respiratory syndrome coronavirus-2 (SARS CoV-2) in Dentistry. Management of biological risk in dental practice. Int J Environ Res Public Health., v. 17, n. 9, p. 3067, Apr 2020. Doi: $10.3390 /$ ijerph17093067.

LUSTIG, S.R. et al. Effectiveness of common fabrics to block aqueous aerosols of virus-like nanoparticles. ACS Nano., v. 14, n. 6, p. 7651-8, Jun 2020. Doi: $10.1021 /$ acsnano.0c03972.

MARANHÃO, K.M.; ESTEVES, R.A. Biossegurança em prótese dentária: proposta de protocolo. Parte I. PCL., v. 6, n. 34, p. 599-604, 2004.

MENG, L. et al. Coronavirus disease 2019 (COVID-19): emerging and future challenges for dental and oral medicine. J Dental Res., v. 99, n. 5, p. 481-7, May 2020. Doi: $10.1177 / 0022034520914246$.

MORAWSKA, L. et al. How can airborne transmission of COVID-19 indoors be minimised? Environ Int., v. 142, n. 105832, Sep 2020. Doi: 10.1016/j. envint.2020.105832.

MORAWSKA, L.; MILTON, D.K. It is time to address airborne transmission of COVID-19. Clin Infect Dis., v. ciaa939 Jul 2020. Doi: $10.1093 / \mathrm{cid} / \mathrm{ciaa939}$.

NEJATIDANESH, F. et al. Risk of contamination of different areas of dentist's face during dental practices. Int J Prev Med., v. 4, n. 5, p. 611-5, May 2013. 
ODEH, N.D. et al. COVID-19: present and future challenges for dental practice. Int J Environ Res Public Health., v. 17, n. 9, p. 3151, Apr 2020. Doi: $10.3390 /$ ijerph17093151.

ORGANIZACÃO PAN-AMERICANA DA SAÚDE (OPAS); Organização Mundial de Saúde (OMS). Orientação sobre o uso de máscaras no contexto da COVID-19. Disponível em: https://iris.paho.org/handle/10665.2/52254. Acesso em: 17 jun 2020.

OTTER, J.A. et al. Evidence that contaminated surfaces contribute to the transmission of hospital pathogens and an overview of strategies to address contaminated surfaces in hospital settings. Am J Infect Control., v. 41, n. 5 Suppl, p. S6-11, May 2013. Doi: 10.1016/j.ajic.2012.12.004.

PAPI, P. et al. Digital prosthetic workflow during COVID-19 pandemic to limit infection risk in dental practice. Oral Dis., May 2020. Doi: $10.1111 /$ odi.13442.

PARANÁ. Governo do Estado. Orientações referentes ao atendimento odontológico nos serviços públicos frente à COVID-19. Nota orientativa 39/2020. Disponível em: http://www.saude.pr.gov.br/ sites/default/arquivos_restritos/files/documento/2020-07/NO_39. ORIENTACOES_REFERENTES_AO_ATENDIMENTO_ODONTOLOGICO_NOS SERV\%20ICOS_PUBLICOS_FRENTE_A_COVID_19_V2.pdf. Acesso em: 25 ago. 2020.

PEDITTO, M. et al. Dentistry during the COVID-19 epidemic: an italian workflow for the management of dental practice. Int J Environ Res Public Health., v. 17. n. 9, p. 3325, May 2020. Doi: 10.3390/ijerph17093325.

PENG, X. et al. Transmission routes of 2019-nCoV and controls in dental practice. Int J Oral Sci., v. 12, n. 1, p. 9, Mar 2020. Doi: 10.1038/s41368020-0075-9.

PIRES, Fabiana Schneider; FONTANELLA, Vania. Consenso Abeno: biossegurança no ensino odontológico pós-pandemia da COVID-19. Porto Alegre: ABENO, 2020. 86p. Disponível em: http://www.abeno.org. br/arquivos/downloads/retomada_de_praticas_seguras_no_ensino. odontologico.pdf. Acesso em: 03 jul. 2020.

ROTHE, C. et al. Transmission of 2019-nCoV infection from an asymptomatic contact in Germany. N Engl J Med., v. 382, n. 10, p. 970-1, Mar 2020. Doi: 10.1056/NEJMc2001468. 
SALZEDAS, L.M.P. et al. Biossegurança na clínica de radiologia odontológica. Arch Health Invest., v. 3, n. 6, p. 6-13, out 2014.

SPAGNUOLO, G. et al. COVID-19 outbreak: an overview on Dentistry. Int J Environ Res Public Health., v. 17, n. 6, p. 2094, Mar 2020. Doi: 10.3390/ ijerph17062094.

UNITED STATES OF AMERICA. Centers for Disease Control and Prevention. Guidance for Dental Settings. Interim infection prevention and control guidance for dental settings during the COVID-19 response. May, 2020. Disponível em: https://www.cdc.gov/coronavirus/2019-ncov/hcp/ dental-settings.html. Acesso em: 07 jun. 2020.

UNIVERSIDADE ESTADUAL PAULISTA. Comissão de Biossegurança. Manual de Biossegurança Faculdade de Odontologia de Araraquara - UNESP. 1 ed. Araraquara. 2009. 40p. Disponível em: https://www. foar.unesp.br/Home/ComissoeseComites/Biosseguranca/manual biosseguranca.pdf. Acesso em: 04 mai. 2020.

van DOREMALEN, N. et al. Aerosol and surface stability of SARS-CoV-2 as compared with SARS-CoV-1. N Engl J Med., v. 382, n. 16, p. 1564-7, Abr 2020. Doi: $\underline{0.1056 / \mathrm{NEJMC2004973} .}$.

WANG, W.K. et al. Detection of SARS-associated coronavirus in throat wash and saliva in early diagnosis. Emerg Infect Dis., v. 10, n. 7, p. 1213-9, Jul 2004. Doi: $\underline{10.3201 / \text { eid1007.031113. }}$

WORLD HEALTH ORGANIZATION. Cleaning and disinfection of environmental surfaces in the context of COVID-19. OMS. Disponível em: https://www.who.int/publications/i/item/cleaning-anddisinfection-of-environmental-surfaces-inthe-context-of-covid-19. Acesso em: 3 jun. 2020.

WORLD HEALTH ORGANIZATION. Getting your workplace ready for COVID-19. OMS. Disponível em: https://www.who.int/docs/defaultsource/coronaviruse/getting-workplace-ready-for-covid-19.pdf?ua=1. Acesso em: 10 abr. 2020.

WORLD HEALTH ORGANIZATION. How is COVID-19 transmitted?. OMS. Disponível em: https://www.who.int/news-room/q-a-detail/q-a-how-iscovid-19-transmitted. Acesso em: 29 jul. 2020. 
WORLD HEALTH ORGANIZATION. What are the symptoms of COVID-19?. OMS. Disponível em: https://www.who.int/emergencies/ diseases/novel-coronavirus-2019/question-and-answers-hub/q-a-detail/ q-a-coronaviruses. Acesso em: 3 mai. 2020.

XU, H. et al. High expression of ACE2 receptor of 2019-nCoV on the epithelial cells of oral mucosa. Int J Oral Sci., v. 12, n. 1, p. 8, Feb 2020. Doi: $10.1038 / \mathrm{s} 41368-020-0074-x$.

$\mathrm{XU}$, Z. et al. Pathological findings of COVID-19 associated with acute respiratory distress syndrome. Lancet Respir Med., v. 8, n. 4, p. 420-2, Apr 2020. Doi: 10.1016/S2213-2600(20)30076-X.

YIN, Y.; WUNDERINK, R.G. MERS, SARS and other coronaviruses as causes of pneumonia. Respirology, v. 23, n. 2, p. 130-7, Feb 2018. Doi: 10.1111/ resp.13196.

YOON, J.G. et al. Clinical significance of a high SARS-CoV-2 viral load in the saliva. J Korean Med Sci., v. 35, n. 20, p. e195, May 2020. Doi: $10.3346 /$ jkms.2020.35.e195.

YU, I.T.S. et al. Evidence of airborne transmission of the severe acute respiratory syndrome virus. N Engl J Med., v. 350, n. 17, p. 1731-9, Apr 2004. Doi: 10.1056/NEJMoa032867. 


\section{SOBRE OS AUTORES}

\section{Shelon Cristina Souza Bandeca}

- Graduada em Odontologia pela Universidade Estadual de Ponta Grossa - UEPG

- Mestre em Odontologia (Área de concentração em Clínica Integrada/Terapêutica) pela Universidade Estadual de Ponta Grossa - UEPG

- Doutora em Odontologia (Área de concentração em Periodontia) pela Faculdade de Odontologia de Araraquara/Universidade Estadual Paulista - FOAr/UNESP

- Professora Adjunta do Departamento de Odontologia e Docente Efetiva no Programa de Pós-Graduação Stricto Sensu em Ciências da Saúde - Universidade Estadual de Ponta Grossa - UEPG

- Campo de estudos: Microbiologia, Periodontia

\section{Vanessa Migliorini Urban}

- Graduada em Odontologia pela Faculdade de Odontologia de Araraquara/Universidade Estadual Paulista - FOAr/UNESP

- Mestre em Reabilitação Oral (Área de concentração em Prótese) pela Faculdade de Odontologia de Araraquara/Universidade Estadual Paulista - FOAr/UNESP

- Doutora em Reabilitação Oral (Área de concentração em Prótese) pela Faculdade de Odontologia de Araraquara/ Universidade Estadual Paulista - FOAr/UNESP

- Professora Adjunta do Departamento de Odontologia e Docente Efetiva no Programa de Pós-Graduação Stricto Sensu em Odontologia - Universidade Estadual de Ponta Grossa - UEPG

- Campo de estudos: Materiais Odontológicos, Prótese 


\section{Ana Cláudia Rodrigues Chibinski}

- Graduada em Odontologia pela Universidade Estadual de Ponta Grossa - UEPG

- Especialista em Odontopediatria pela Universidade Federal do Paraná - UFPR

- Mestre em Odontologia (Área de concentração em Clínica Integrada) pela Universidade Estadual de Ponta Grossa - UEPG

- Doutora em Odontologia (Área de concentração em Clínica Integrada) pela Universidade Estadual de Ponta Grossa - UEPG

- Professora Adjunta do Departamento de Odontologia e Docente Efetiva no Programa de Pós-Graduação Stricto Sensu em Odontologia - Universidade Estadual de Ponta Grossa - UEPG

- Campo de estudos: Mínima Intervenção em Odontologia

\section{Denise Stadler Wambier}

- Graduada em Odontologia pela Universidade Estadual de Ponta Grossa - UEPG

- Mestre em Ciências Odontológicas (Área de concentração em Odontopediatria) pela Faculdade de Odontologia da Universidade de São Paulo - FOUSP

- Doutora em Ciências Odontológicas (Área de concentração em Odontopediatria) pela Faculdade de Odontologia da Universidade de São Paulo - FOUSP

- Professora Titular em Clínica Integrada Infantil e Cariologia do Departamento de Odontologia e Docente Efetiva no Programa de Pós-Graduação Stricto Sensu em Odontologia - Universidade Estadual de Ponta Grossa - UEPG

- Campo de estudos: Mínima Intervenção em Odontologia

\section{Eduardo Bauml Campagnoli}

- Graduado em Odontologia pela Pontifícia Universidade Católica do Paraná - PUC/PR 
- Mestre em Odontologia (Área de concentração em Estomatologia) pela Pontifícia Universidade Católica do Paraná - PUC/PR

- Doutor em Estomatopatologia pela Faculdade de Odontologia de Piracicaba/Universidade Estadual de Campinas - FOP/ UNICAMP

- Professor Adjunto do Departamento de Odontologia, Docente Efetivo no Programa de Pós-Graduação Stricto Sensu em Ciências da Saúde e Tutor dos Programas de Residência Multiprofissional em Intensivismo e Saúde do Idoso, vinculados ao Hospital Universitário Regional dos Campos Gerais - Universidade Estadual de Ponta Grossa - UEPG

- Campo de estudos: Diagnóstico Bucal e Odontologia Hospitalar

\section{Fábio André dos Santos}

- Graduado em Odontologia pela Pontifícia Universidade Católica de Campinas - PUC/Campinas

- Mestre em Odontologia (Área de concentração em Periodontia) pela Faculdade de Odontologia de Araraquara/Universidade Estadual Paulista - FOAr/UNESP

- Doutor em Odontologia (Área de concentração em Periodontia) pela Faculdade de Odontologia de Araraquara/Universidade Estadual Paulista - FOAr/UNESP

- Professor Associado do Departamento de Odontologia e Docente Efetivo no Programa de Pós-Graduação Stricto Sensu em Odontologia - Universidade Estadual de Ponta Grossa - UEPG

- Campo de estudos: Periodontia, Clínica Integrada

\section{Fábio Brasil de Oliveira}

- Graduado em Odontologia pela Universidade Estadual de Ponta Grossa - UEPG

- Mestrando em Odontologia (Área de concentração em Clínica Integrada) pela Universidade Estadual de Ponta Grossa - UEPG

- Campo de estudos: Diagnóstico e terapêutica de doenças bucais 


\section{Gilson César Nobre Franco}

- Graduado em Odontologia pela Pontifícia Universidade Católica de Campinas - PUC/Campinas

- Especialista em Farmacologia Clínica pela Universidade Metodista de Piracicaba - UNIMEP

- Especialista em Radiologia Odontológica e Imaginologia pelo Instituto e Centro de Pesquisas São Leopoldo Mandic

- Doutor em Farmacologia, Anestesiologia e Terapêutica pela Faculdade de Odontologia de Piracicaba/Universidade Estadual de Campinas - FOP/UNICAMP

- Professor Adjunto do Departamento de Odontologia e Docente Efetivo no Programa de Pós-Graduação Stricto Sensu em Odontologia - Universidade Estadual de Ponta Grossa - UEPG

- Campo de estudos: Diagnóstico e terapêutica de doenças bucais

\section{João Carlos Gomes}

- Graduado em Odontologia pela Universidade Estadual de Ponta Grossa - UEPG

- Mestre em Dentística Restauradora pela Faculdade de Odontologia de Araraquara/Universidade Estadual Paulista - FOAr/UNESP

- Doutor em Dentística Restauradora pela Faculdade de Odontologia de Araraquara/Universidade Estadual Paulista - FOAr/UNESP

- Professor Titular em Dentística Restauradora do Departamento de Odontologia e Docente Efetivo no Programa de PósGraduação Stricto Sensu em Odontologia - Universidade Estadual de Ponta Grossa - UEPG

- Campo de estudos: Materiais Odontológicos, Dentística 


\section{Luís Antônio Esmerino}

- Graduado em Ciências Biológicas (Modalidade Médica) pela Universidade Metodista de Piracicaba - UNIMEP

- Graduado em Farmácia pela Universidade Metodista de Piracicaba - UNIMEP

- Especialista em Análises Clínicas pela Universidade São Judas Tadeu

- Mestre em Odontologia pela Faculdade de Odontologia de Piracicaba/Universidade Estadual de Campinas - FOP/ UNICAMP

- Doutor em Odontologia pela Faculdade de Odontologia de Piracicaba/Universidade Estadual de Campinas - FOP/ UNICAMP

- Professor Associado do Departamento de Análises Clínicas e Toxicológicas e Docente Colaborador dos Programas de Pós-Graduação em Ciências Farmacêuticas e Tecnologia dos Alimentos - Universidade Estadual de Ponta Grossa - UEPG

- Campo de estudos: Microbiologia, Farmacologia

\section{Nara Hellen Campanha Bombarda}

- Graduada em Odontologia pela Fundação Educacional de Barretos

- Doutora em Reabilitação Oral (Área de concentração em Prótese) pela Faculdade de Odontologia de Araraquara/ Universidade Estadual Paulista - FOAr/UNESP

- Professora Associada do Departamento de Odontologia e Docente Efetiva no Programa de Pós-Graduação Stricto Sensu em Odontologia - Universidade Estadual de Ponta Grossa - UEPG

- Campo de estudos: Materiais Odontológicos, Prótese 